\title{
نزعات ابن آجروم الكوفيّة في متن الأجروميّة
}

\section{م • د. محمد سعد محمد أحمد (")}

الملخص :

تهدف هذه الدراسة إلى النظر في آراء ابن آجروم الصنهاجي النحويّة في كتابه "مقدمة

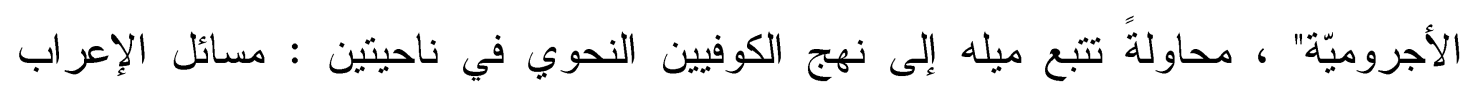
و البناء وما يتصل بهما ، وناحية المصطلحات النحويّة .

وقد شدّ عزيمتي للنظر في هذا الموضوع أنّ بعضاً من كتب النحو ومدارسه عدّت ابن آجروم من العلماء الكوفيين ، أو الذين يستظهرون المذهب الكوفي النحوي وجُعل آخرهم ،

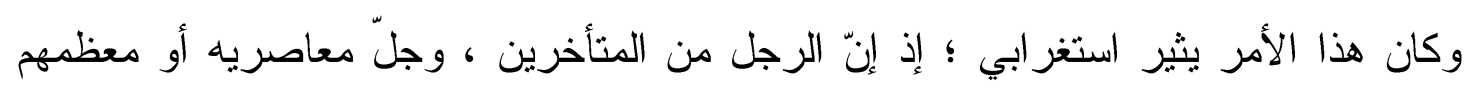

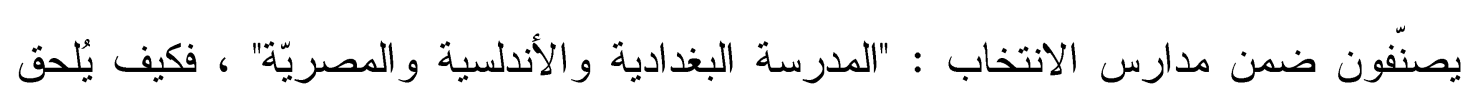

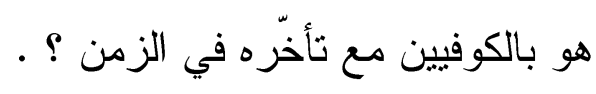
وسوف يستبين في السطور القادمة - بإذن الله تعالى - أنّ هذا العالم كان يميل في آرائه

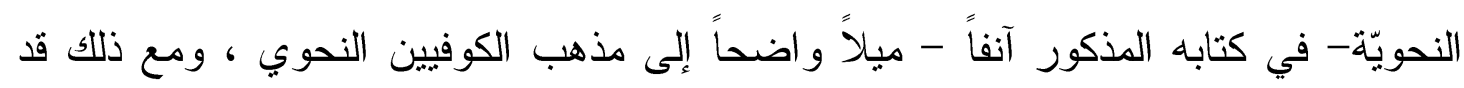
يظهر عنده جنوح إلى رأي البصريين أحياناً ، وكلّ هذا وغيره سيرد تفصيل شأنه فيما يتلو من حديث .

وستتدرج الدراسة في هذا الشأن وتتسلسل بشكل موضوعي ؛ حيث تكون البداية من نشأة النحو العربيّ وأسبابها ، ثم يأتي الحديث عن مدرستي البصرة و الكوفة و المدارس اللاحقة ، ومن ثم تذكر سيرة ابن آجروم وكتابه "الأجرومية" ، وبعد ذلك يأتي تفصيل الكلام في آرائه النحوية في الإعر اب و البناء ومتعلقاتهما ، وفي المصطلحات النحوية ، وصلة ذلك ولك كله بنهج الكوفيين .

(") أستاذ النحو والصرف المساعد ، قسم اللغة العربية ، كلية العلوم والآداب برنية - جامعة الطائف ، المعار من قسم اللغة العربية - كلية التربية - جامعة الخرطوم . .mohammedahamedrr@yahoo.com. 


\section{$\underline{\text { Abstract }}$}

The present study intends to explore views and perspectives of the Arab grammarian Ibn-ajroom Al-sanhaaji throughout his book "An introduction to Ajroomism ". More specifically, this study tries to examine Ibn-ajroom tendency to adopt the approach of Alkufa doctrine of Arabic language grammar in two ways : parsing or sentence structure analysis and grammatical terminologies .

What actually lead me to consider this issue is several attempts that made by a lot of Arab grammarians in order to regard Ibn -Ajroom as one of those grammarians who belong to Alkufa school of the Arabic grammar in spite of the fact that he was a latecomer grammarian and most of his contemporaries or generation belong to the elective approach of syntactic and grammatical analysis which are Baghdadi, Andalusia and Egyptian schools of grammar. This of course, raised a very important question into my mind that is : how can we consider Ibn -ajromm as a keen follower to Alkfua doctrine of grammar though he came historically after the presence of this school of grammar .

As it will be shown throughout this study, this Arab scholar has revealed great tendency towards adopting grammatical viewpoints that mainly introduced by Alkufa school of grammar however, some of his own findings, views and perspectives in this regard have been found to be consistent and in line and conformity with those of Albisraha school of Arabic grammar.

In the first part of this study the earliest emergence of the Arabic language grammar and its origins will be thoroughly reviewed followed by a brief account of the two major schools of Arabic language grammar : Albisrha and Alkufa and then a comprehensive and full biography of Ibn-ajroom will be given before to highlight and discuss his own views, insights and perceptions regarding grammatical structure and sentence parsing and explain how they are much interrelated and consistent with Alkufa school of Arabic language grammar. 
أيّ علمٍ من العلوم أو فنّ من الفنون كائن حيّ يخضع لما يخضع له الأحياء من سنن الحياة

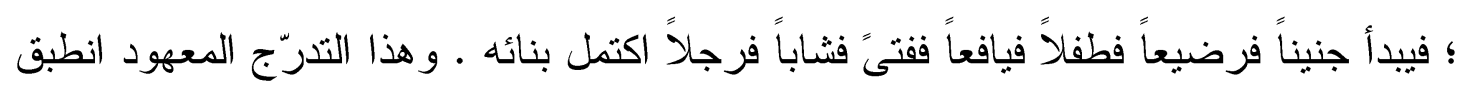

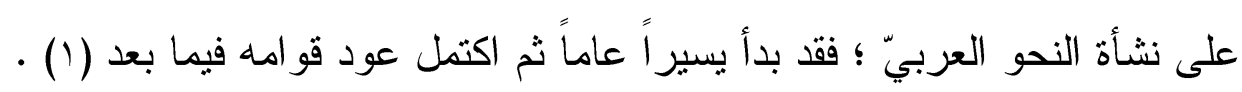
وتثير معظم المصادر إلى أولّيّة أبي الأسود الدؤلي ظالم بن عمرو بن سفيان في هذا العلم

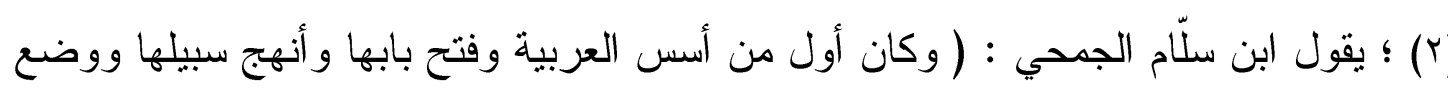

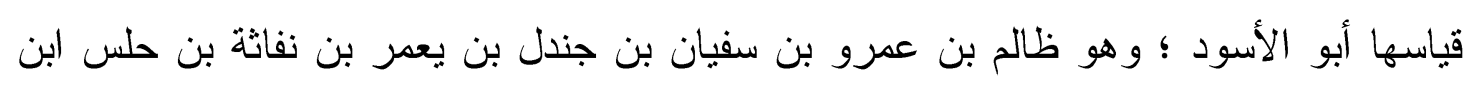

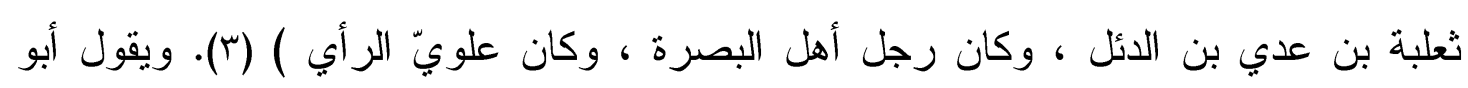

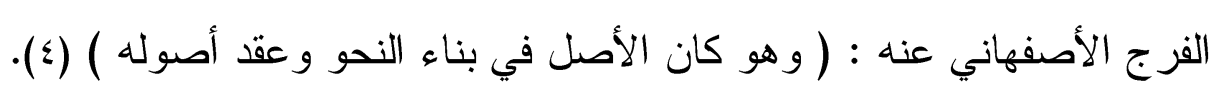
واختلفت الروايات في سبب وضعه النحو ؛ فمنها ما يقول : أنّه عندما سُئل من أين للك هذا العلم (يعنون النحو) ؟ أجاب : لُقتنت حدوده من عليّ بن أبي طالب عليه السلام . ومنها أيضاً

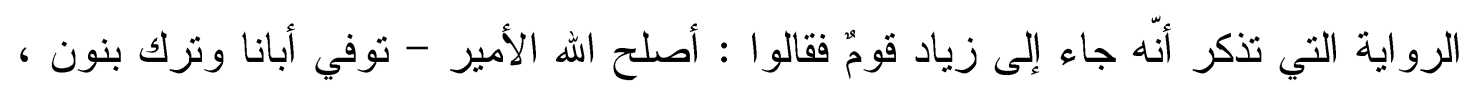

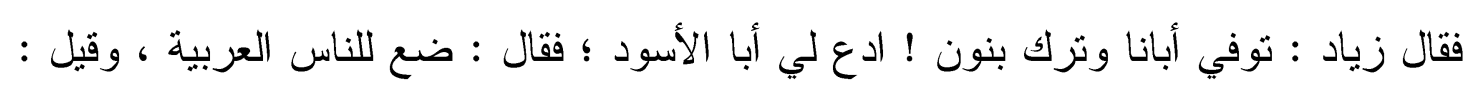

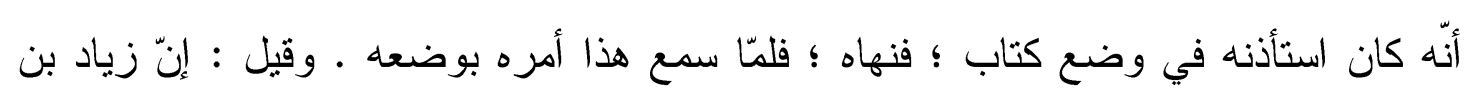
أبيه قال لأبي الأسود : إنّ بنيّ يلحنون في القرآن ؛ فلو رسمث لهم رسماً ؛ فنقّط المصحف

وقيل : إنّ ابنةً لأبي الأسود قالت له : يا أبت ما أشدُّ الحر ! فقال لها : إذا كانت الصقعاء من فوقلك والرمضاء من تحتلك ، فقالت : إنّما أردت أنّ الحرّ شديد ، فقال لها : فقولي إذن :

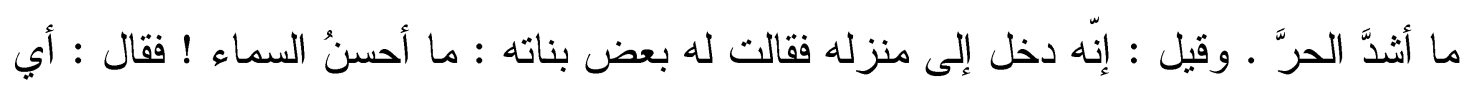

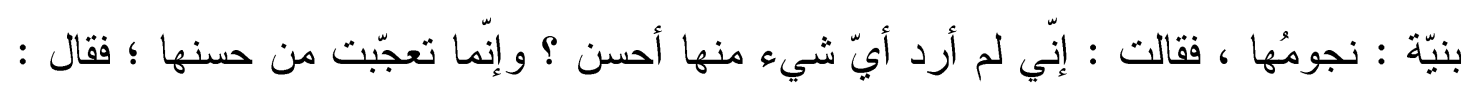

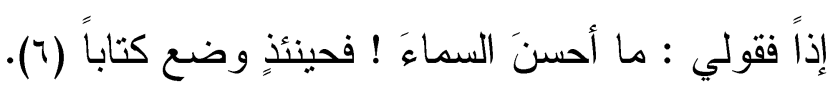


وقيل : أتى أبو الأسود عبد الله بن عباس ؛ فقال : أرى ألسنة العرب قد فسدت ؛ فأردت أن

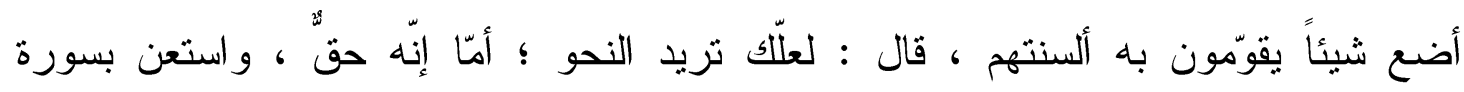
يوسف(v). (v) وقيل : إنّه لكّا ولي زياد العراق بعث إليه بقوله له : اعمل شيئاً تكون فيه إماماً تُعرب به

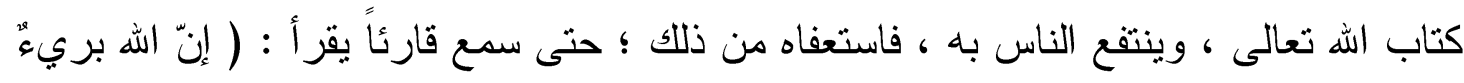

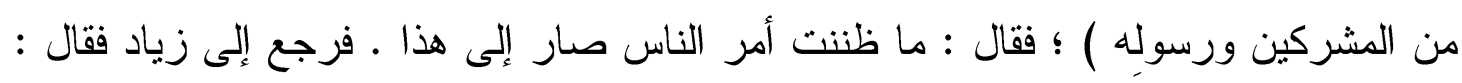

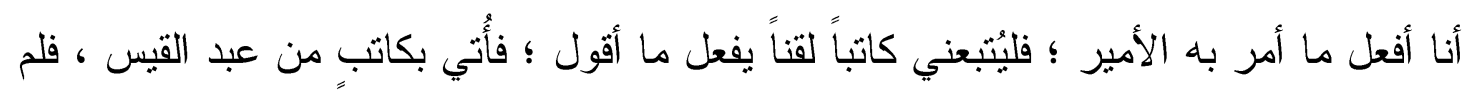

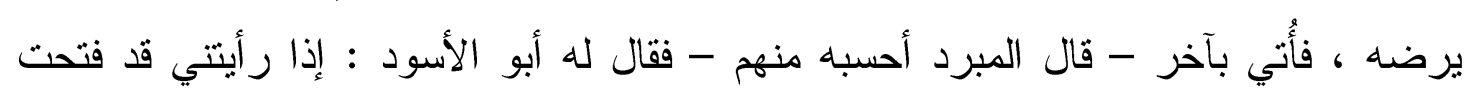
فمي بالحرف فانقط فوقه نقطة ، و إذا رأينتي قد ضمدت فمي فانقط نقطة بين يدي الحرف ،

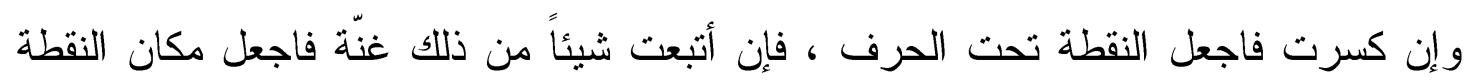

نقطنين(^).

ويُجمع معظم من كتب في تاريخ النحو من القدامى على أسبقية أبي الأسود في بدء وضع النحو العربي مع اختلافهم في أسباب قيامه بذلك وطرقه ، ولكنّ شوقي ضيف في كتابه

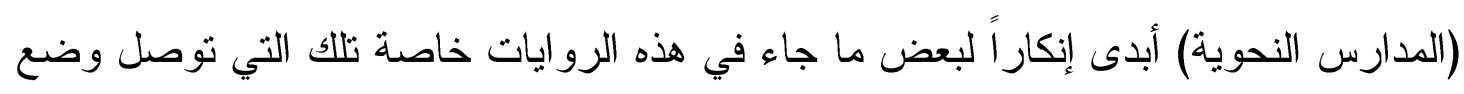
النحو إلى أمير المؤمنين عليّ بن أبي طالب رضي الله عنه عبر أبي الأسود ، وظنّ أنّ ذلك ألك

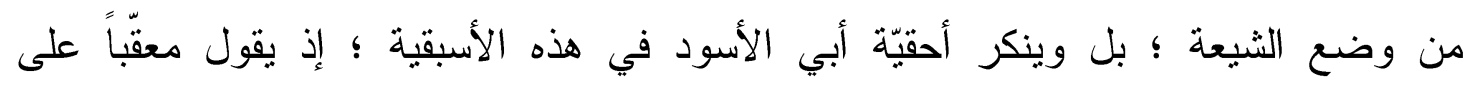

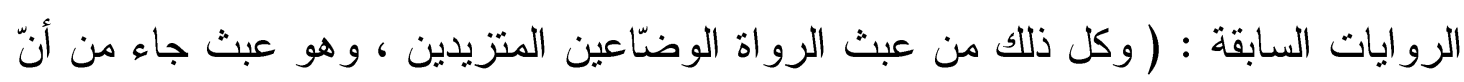

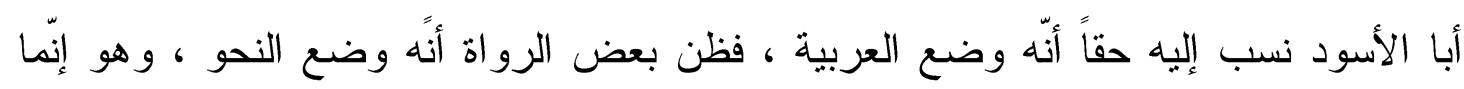
وضع أول نقط يحرر حركات أواخر الكلمات في القرآن الكريم بأمر من زياد بن أبيه أو ابنه

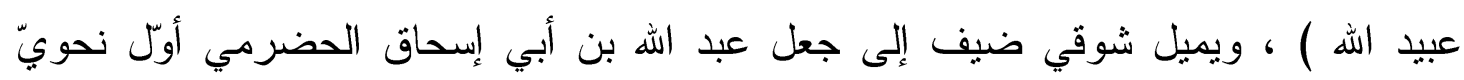

حقيقيّ (9) (9)

ولعل قر ائن الأشياء لا تسند ما ذهب إليه شوقي ضيف ؛ لأنّ نسبة بداية القول في هذا العلم إلى أبي الأسود ناحية ذهب إليها معظم القدامى ممّن هو أقرب عصراً من زمن أبي الأسود كابن سلام الجمحي وغيره من الثقاة في الرواية ، كما أنّ تحرير نقط الإعراب التي أثتبت التهن 
لأبي الأسود من قبل الرواة ومن قبل شوقي ضيف نفسه تُعدّ بداية في هذا العلم ، وربما تكون

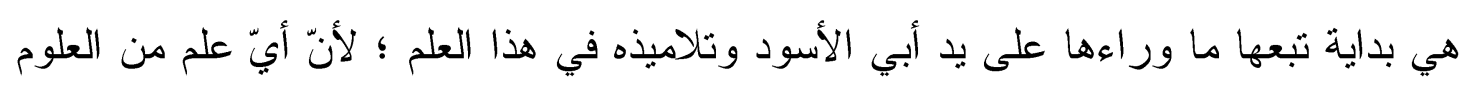

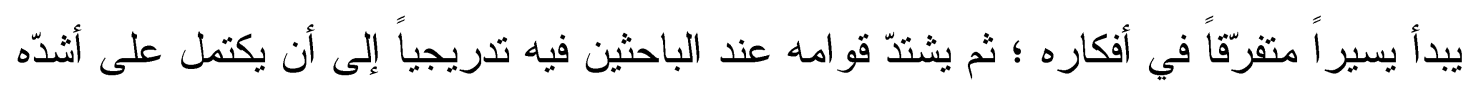

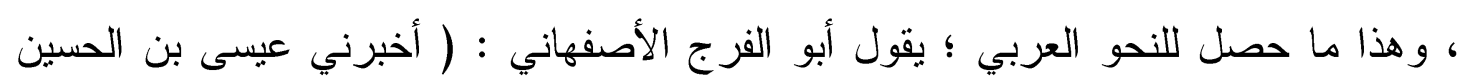
قال : حدّثنا حمّاد ابن إسحاق عن أبيه عن المدائني قال : أمر زياد أبا الأسود الدؤلي أن ينقط

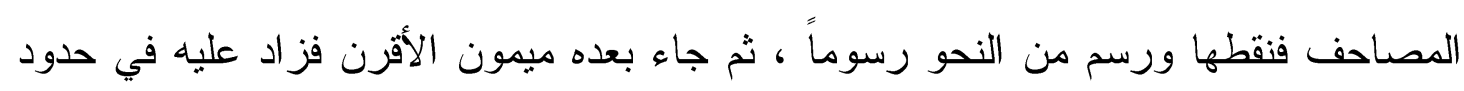
العربية ، ثم زاد فيها بعده عنبسة بن معدان المهري ، ثم جاء عبد الله بن أبي إسحاق

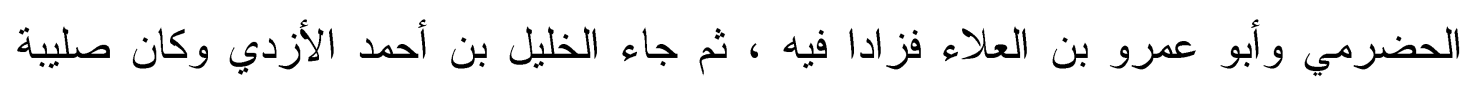
فلحب الطريق (·() ، ونجم عليّ ابن حمزة الكسائي مولى بني كاهل من أسد فرسم للكوفيين رسوماً وهم الآن يعملون عليها) (1'). (1).

ويضاف إلى ذلك أنّ أبا الأسود كان علويّ الرأي يجاهر بتشيّّها وهواه فيمدح الإمام عليّ

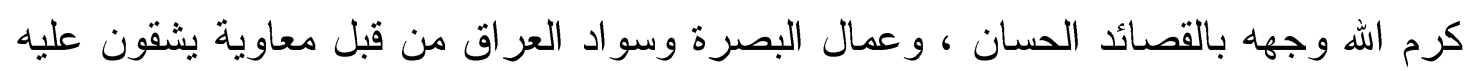

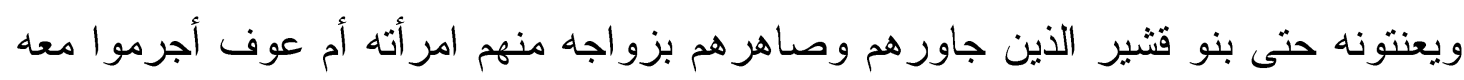

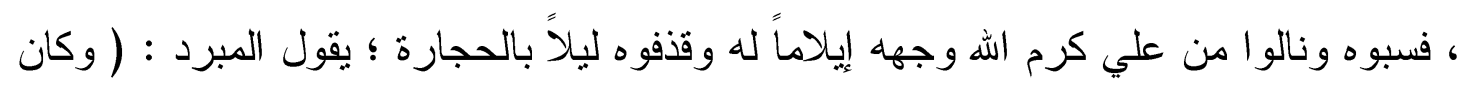

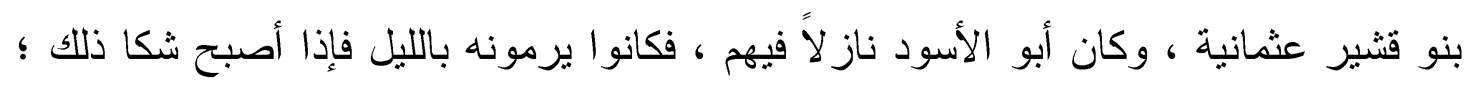

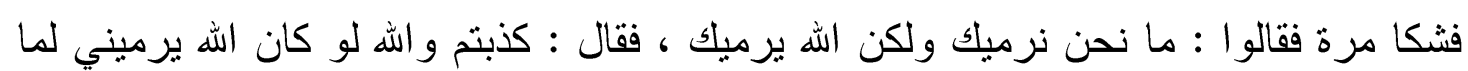

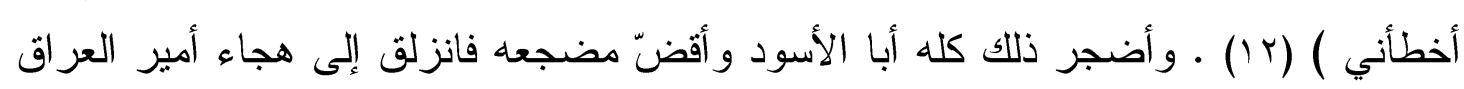

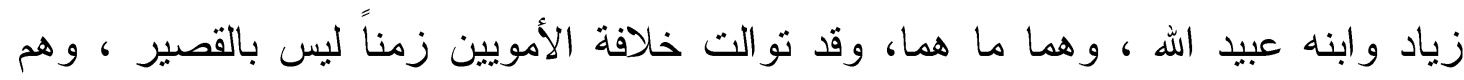

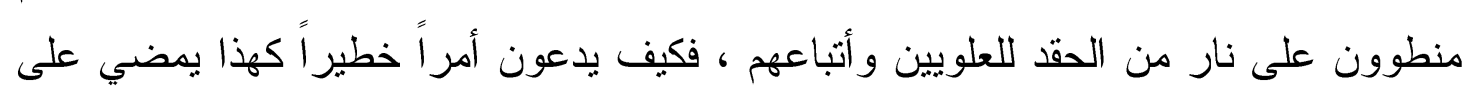

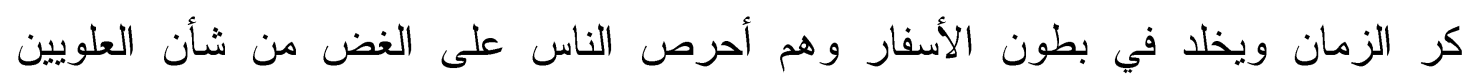

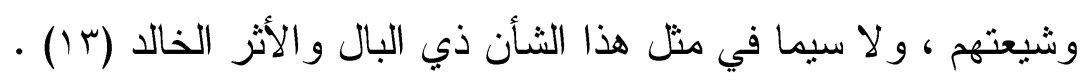

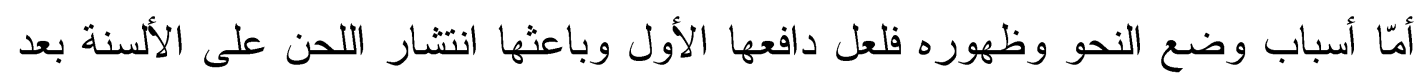

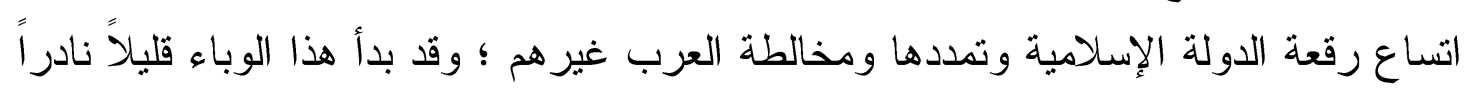

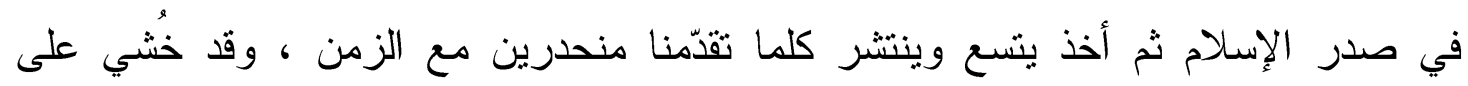

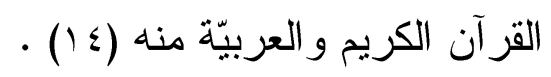


وتُروى عدة حوادث لظهور اللحن منذ صدر الإسلام وحتى الشروع في وضع هذا العلم وظهور الضوابط التي يُعرف بها الصواب من الخطأ ؛ فقد رُوي أنّ النبي صلى الله عليه وسلم سمع رجلاً يلحن في كلامه فقال : ( أرشدو ا أخاكم فإنه قد ضلّ ) (10) . وفي عهد الخلفاء الراشدين ظهرت حوادث عدة للحن منها ما رُوي من أنّ أعر ابيّاً قدم في خلافة أمير المؤمنين عمر بن الخطاب رضي الهه عنه ؛ فقال : من يُقرئني شيئًا مدّا أنزل الله على محمد صلى الله عليه وسلم ، فأقر أه رجلّ سورة براءة فقال : ( إنّ الله بريءٌ من المشركين ورسوله ) بالجرّ؛ فقال الأعر ابيّ : أو قد برىئ الله من رسوله ! إن يكن الله برىئ من بن

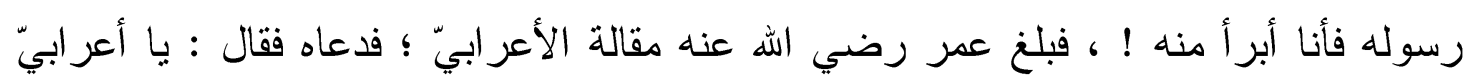
أتبرأ من رسول الله ! ، فقال : يا أمير المؤمنين إني قدمت المدينة ولا علم لي بالقرآ ؛ فسألت : من يُقرئني؟ ، فأقرأني هذا سورة براءة ، فقال : ( إنّ الله بريءٌ من المشركين ورسوله ) ، فقلت: أو قد برئ الله تعالى من رسوله ! إنّ يكن برئ من رسوله ، فأنا أبرأ منه له • فقال له عمر رضي الله عنه : ليس هكذا با أعرابي ، فقال : كيف هي يا أمير المؤمنين ؟

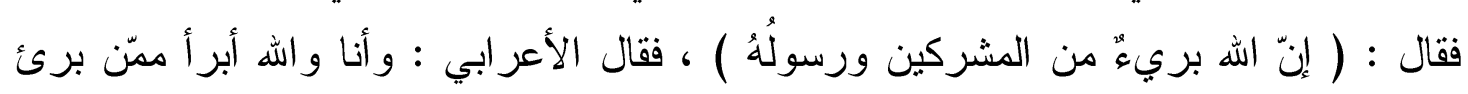

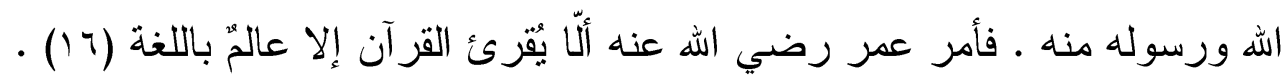
ثم شاع اللحن في العصر الأمويّ حتى تطرق إلى البلغاء من الخلفاء والأمر اء كعبد الملك و الحجّاج ، و الناس يومئذٍ تتعاير به ، وكان ممّا يُسقط الرجل في المجتمع أن يلحن ، حتى قال عبد الملك - وقد قيل له : أسرع إليك الشيب - : شيّيتني ارتقاء المنابر مخافة اللحن . وكان يقول : إنّ الرجل يسألني الحاجة فتستجيب نفسي له بها ، فإذا لحن انصرفت نفسي عنها . و الحجاج مع أنّه من الخطباء البلغاء كان في طبعه تثزز من اللحن أن يقع منه أو من غيره ، فإذا وقع منه حرص على ستره و إبعاد من اطلع عليه منه ، وذكروا أنّه سأل بحيى بن يعمر الليثي : أتسمعني ألحن على المنبر؟ ؛ فقال يحيى : الأمير أفصح الناس إلّا أنّه لم يكن يروي الشعر ، قال: أتسمعني ألحن حرفاً ؟ ؛ قال : نعم ؛ في آي القرآن ؛ قال : فذالك أشنع ؛ وما

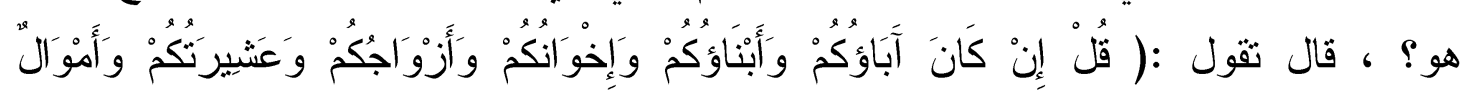

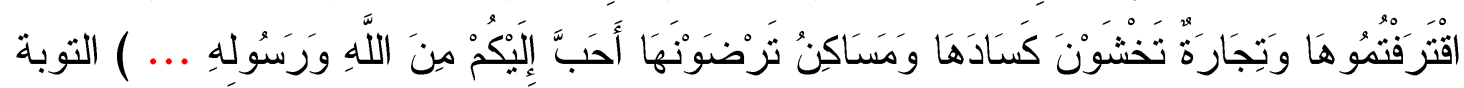

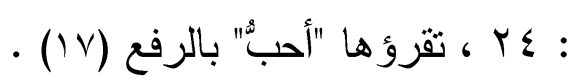

و هؤلاء أصابهم قليل" من اللحن لبعدهم عن قومهم في الجزيرة العربية مع أنهم نشأو الفيها وترعرعو ا و اكتهلو ا ؛ فلمّا كان من بعدهم عظم فشو اللحن فيهم حتى كان من أعظم المصائب

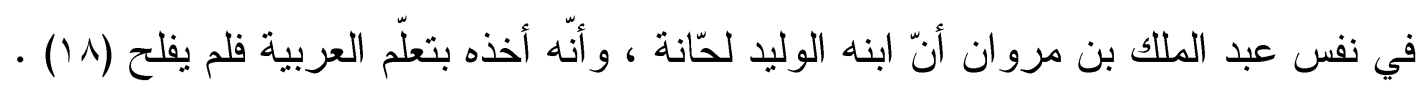


وتقتضي طبائع الأشياء أن يكون الشيء غير المستحبّ نادراً وقليل الحدوث عند القادة و الأمر اء ولكنّه قد يكثر بين العامة ، وهذا ما ينطبق على اللحن فهو - على ما يبدو - منتشر" بين العو ام ؛ فالروايات تدللّ على ذللك ؛ فقد رُوي عن عمر بن عبد العزيز قوله : (إنّ الرجل ليكلمني في الحاجة بستوجبها فيلحن فأردّه عنها ، وكأني أقضم حبّ الرمّان الحامض ؛

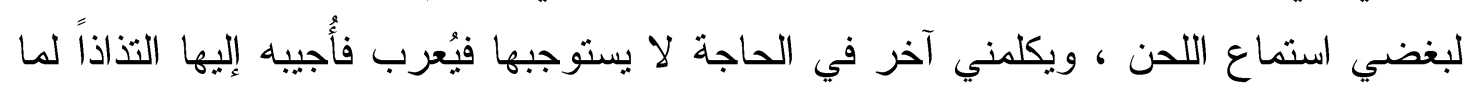
أسمع من كلامه) • ورُوي عنه أيضاً قوله : (أكاد أضرس إذا سمعت اللحن) (9 (1) . و إذا وصلنا إلى العصر العباسي وجدنا أنّ اللحن قد بلغ مبلغاً عظيماً عند الناس في ذاك الزمن ؛ إذ ازدادت مخالطة العرب للشعوب الأعجمية التي أر ادت أن تتكلّم العربية فلم تستطع مجع المحافظة على سلامتها من الخطأ في اللفظ والحركات (•r) • يقول الجاحظ : ( ثم اعلم أن أقبح اللحن لحن أصحاب التقعير و التقعيب (r) ، و التشديق و التمطيط و الجهورة و التفخيم . و أقبح من ذلك لحن الأعاريب النازلين على طرق السابلة ، وبقرب مجامع الأسواق ) (rY) . ويضيف الجاحظ :( وزعم أبو العاصي أنّه لم ير قروياً قط لا يلحن في حديثه ، وفيما يجري بينه وبين الناس ، إلّا ما تفقده من أبي زيد النحوي ، ومن أبي سعيد المعلم ) (rr) . و هكذا انتشر اللحن بين العامة والخاصة من الناس ؛ مدّا نبّه القائمين على الأمر و المهتمين باللغة إلى ضرورة وضع رسوم يعرف بها الصواب من الخطأ ؛ خاصة وأنّ هذا الخطر أخذ

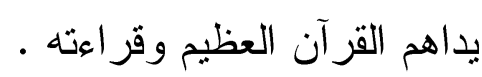
وقد انضمت لهذا السبب الرئيس السابق في نشأة النحو أسباب أخرى جانبية منها : اعنزاز العرب بلغتهم اعتزازاً شديداً وخشيتهز عليها من الفساد بممازجة الأعاجم ممّا قد يؤدي إلى آلى ذوبانها في اللغات الأجنبية ، ويُضاف إلى ذلك سبب آخر اجتماعيّ وهو : أنّ الشعوب المستعربة الداخلة في الإسلام أحسّت بالحاجة الثديدة لمن يرسم أوضاع العربية في إعرابها

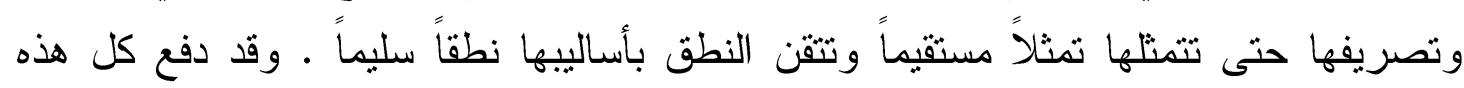
الأسباب وارتقى بها إلى إمكانية ظهور النحو العربي و اقعاً عاملٌ جانبيٌّاُ آخر وهو رقي العقل العربي ونمو طاقته الذهنية نمواً أعدّه للنهوض برصد الظواهر اللغوية وتسجيل الرسوم النحوية تسجيلًا تطرّد فيه القو اعد وتتنظم الأقيسة انتظاماً يهيأ لنشوء علم النحو ووضع قو انينه الجامعة المشتقة من الاستقاء الدقيق للعبارات و التراكيب الفصيحة ، ومن المعرفة التامة بخو اصها وأوضاعها الإعر ابية (ع ب) . 
ثانياً : المدارس النحويّة ومذاهبها ونهجها :

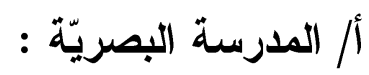

هي أوّل المدارس النحوية على الإطلاق ، وهي الني أقامت أركان النحو ورفعت عماده

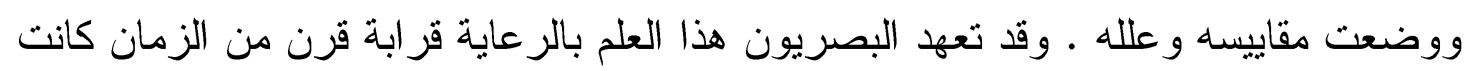

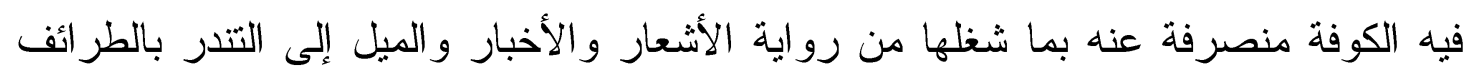

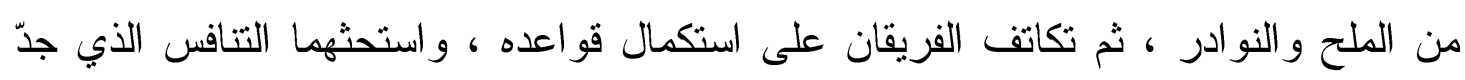

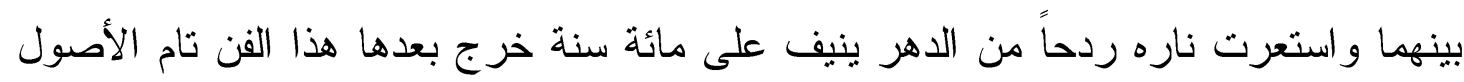

كامل العناصر (ro)

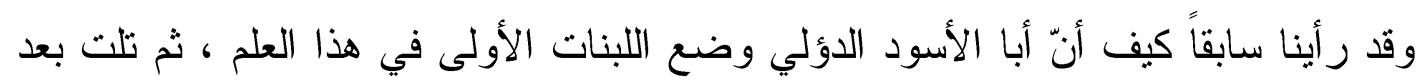

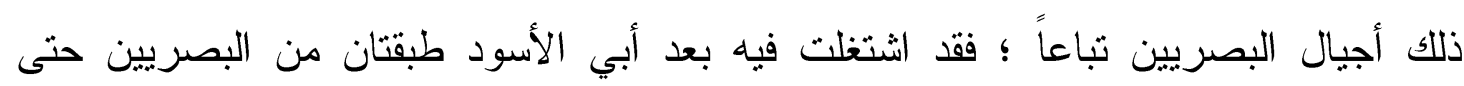

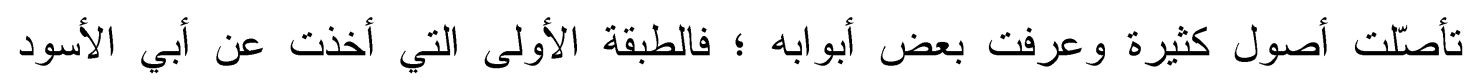

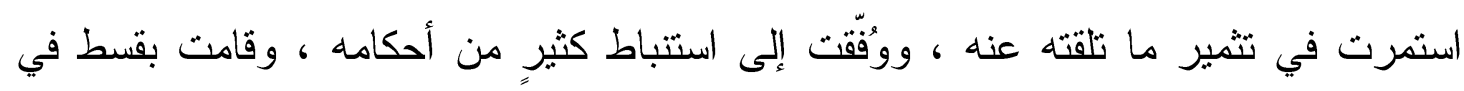

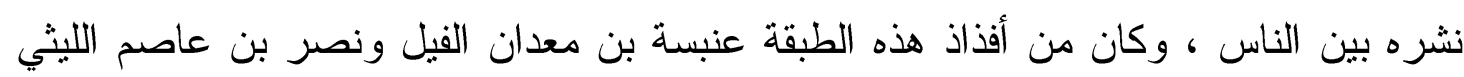
وعبد الرحمن بن هرمز ويحيى بن يعمر العدواني ، ولم يدرك أحد من رجال هذه الطبقة

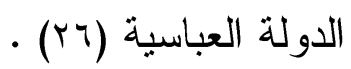

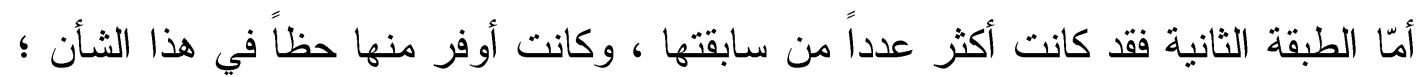

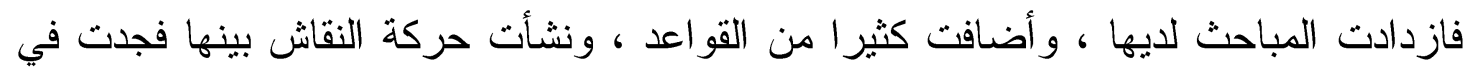

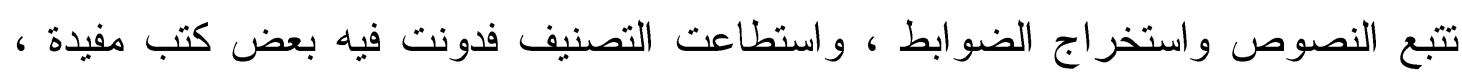

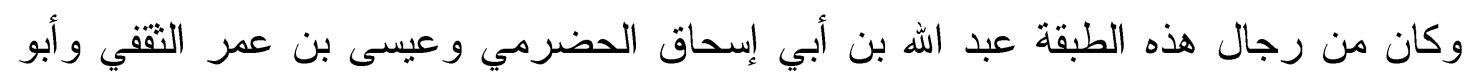

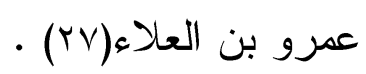
وتلا هذه الطبقة الثانية من البصريين الجيل الذي تكاملت على يديه أركان النحو العربي في

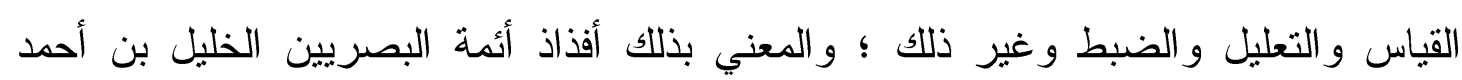

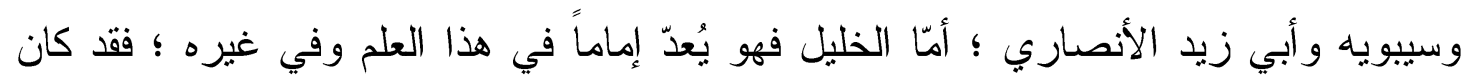

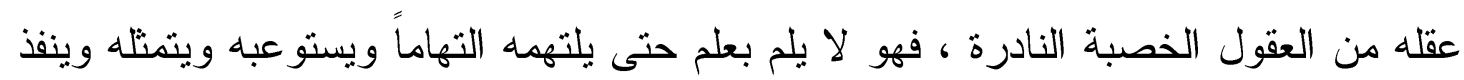

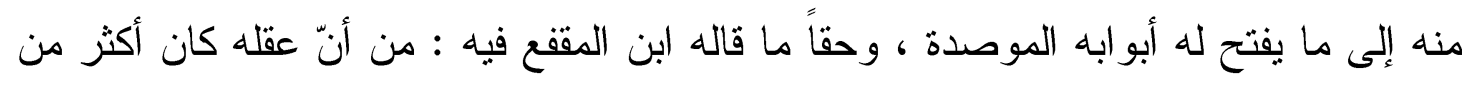
علمه ، وهو عقل جعله يتصل بكل علم ويحوز لنفسه منه كل ما يبتغي من ثراء في التفكير

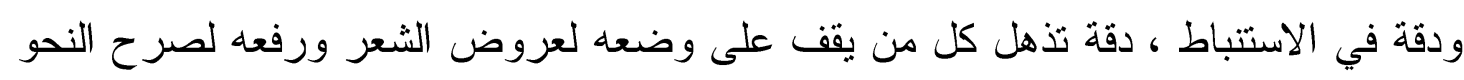

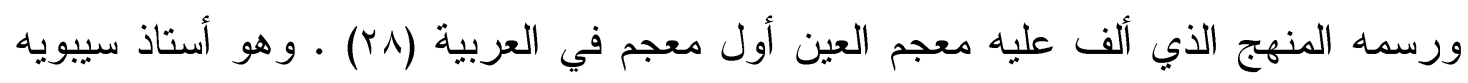


وعامة الحكاية في كتابه عنه ؛ فكلّما قال سيبويه : سألته أو قال من غير أن يذكر المسؤول

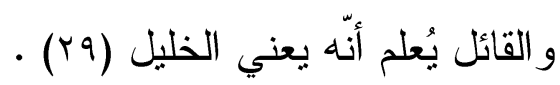

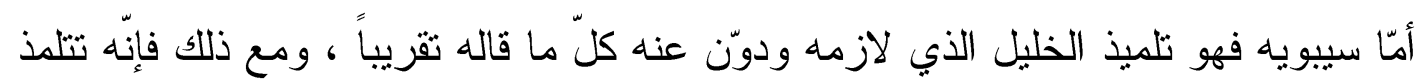

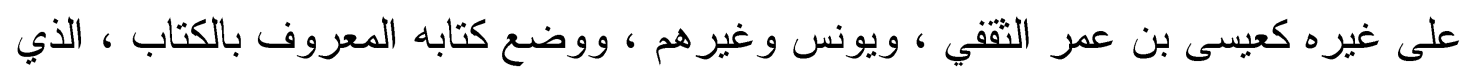

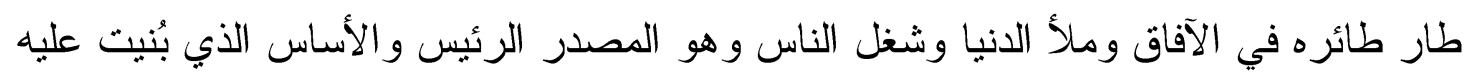

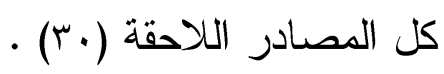
ثم تتابعت بعد ذلك أجيال العلماء البصريين الذين صنفوا المصنفات على مرّ العصور ؛

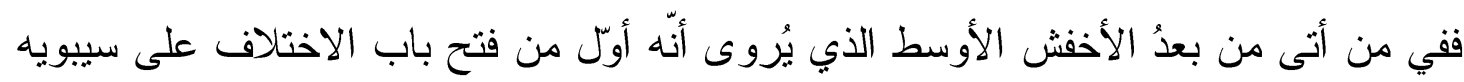

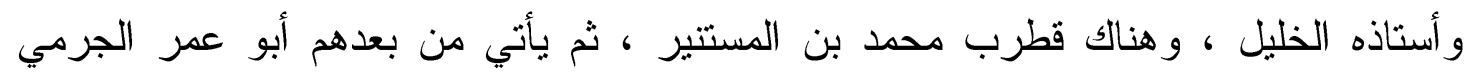

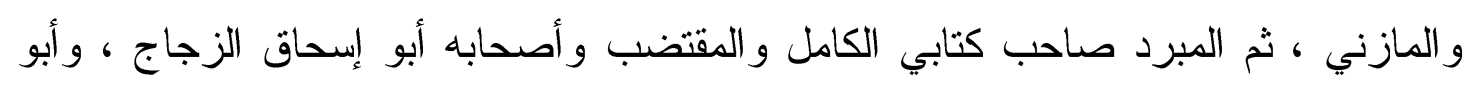

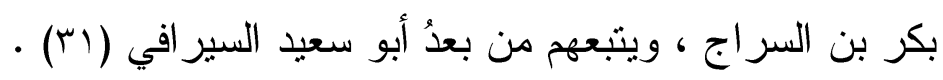

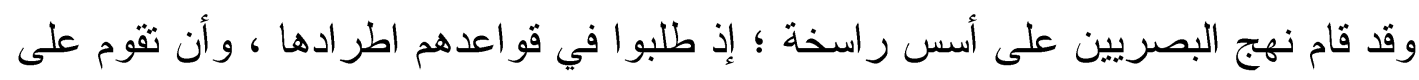

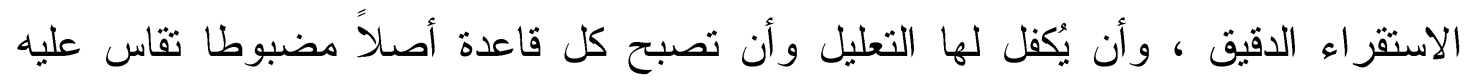

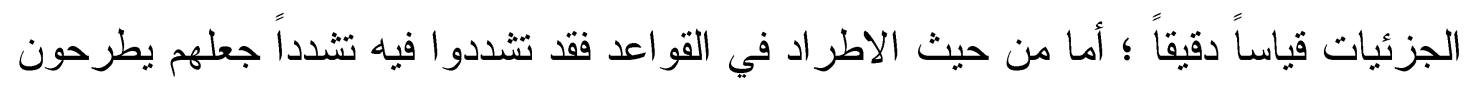

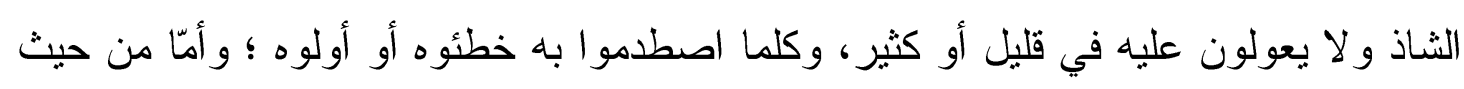

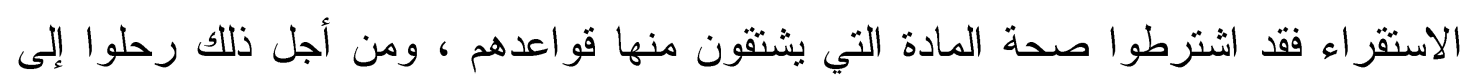

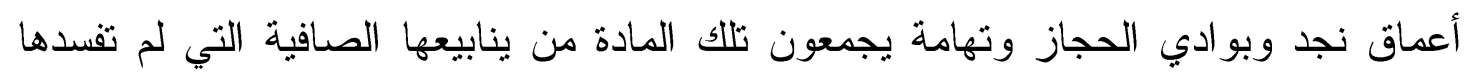
الحضارة ، وبعبارة أخرى : رحلوا إلى القبائل المتبدية المحتفظة بملكة اللغة وسليقتها

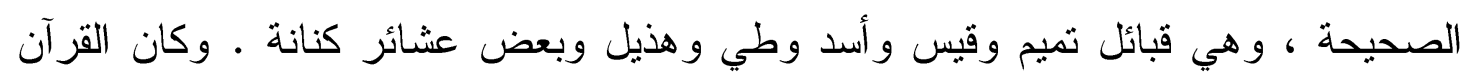

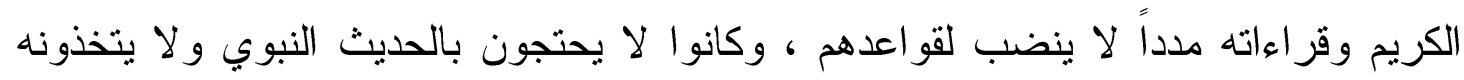

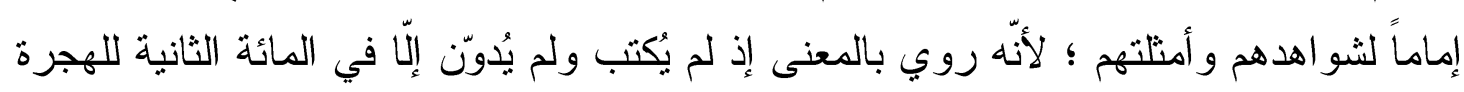
، ودخلت في روايته كثرة من الأعاجم (r؟r) .

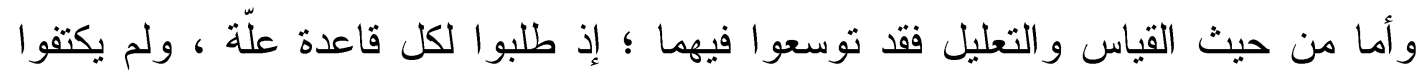

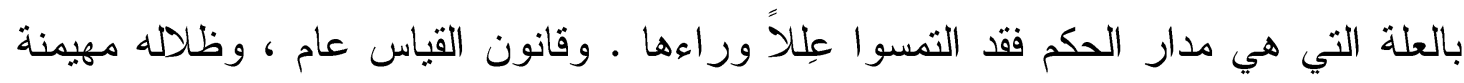

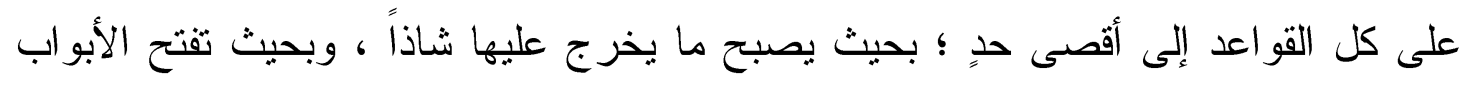

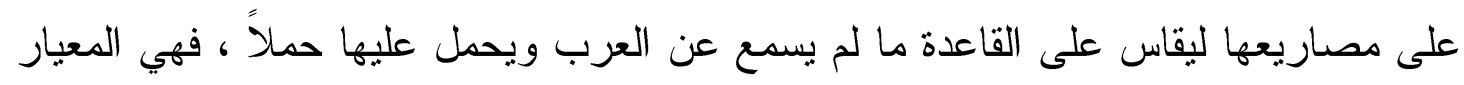

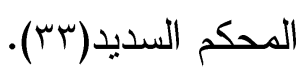

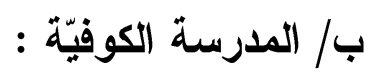


وهي المدرسة الثانية في النشأة ، وقد انشغل علماء الكوفة بادئ الأمر بالفقه ووضع أناء

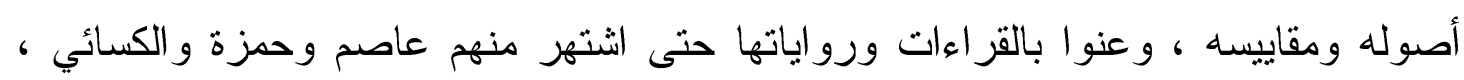

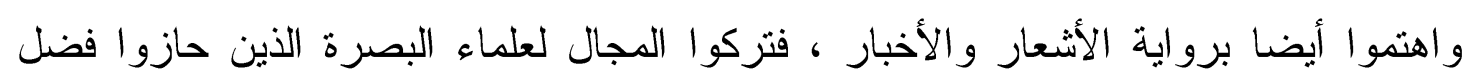
السبق في علم النحو و الصرف (عَّ) . وتذكر المصادر أنّ أولّ نحويّ كوفي هو أبو جعفر الرؤاسي الذي طلب العلم في البصرة

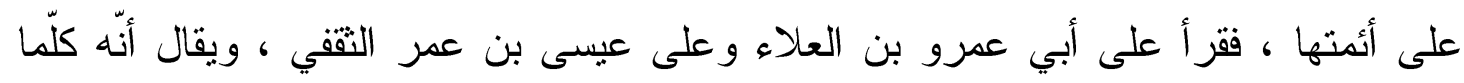

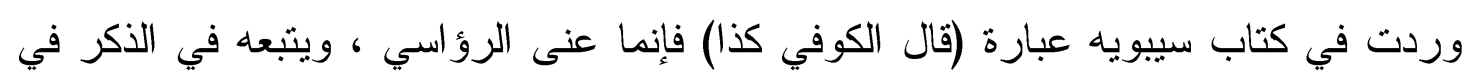

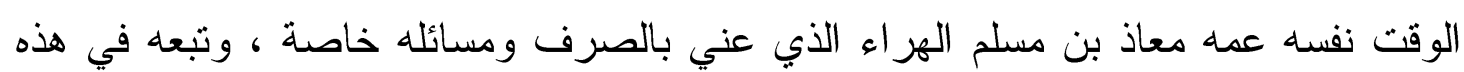

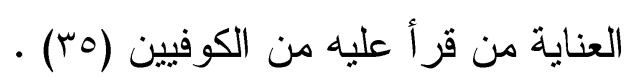

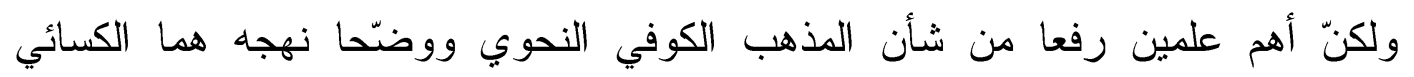

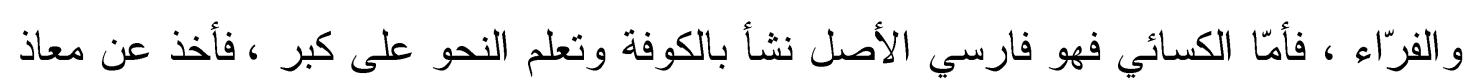

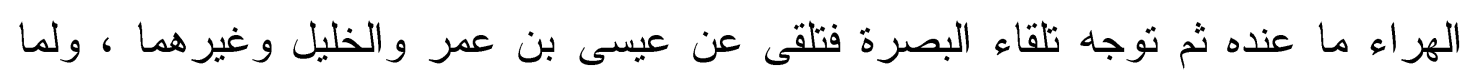

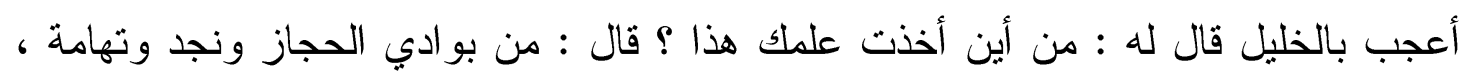

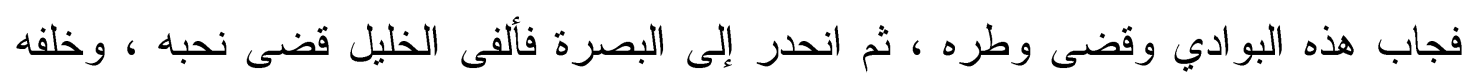

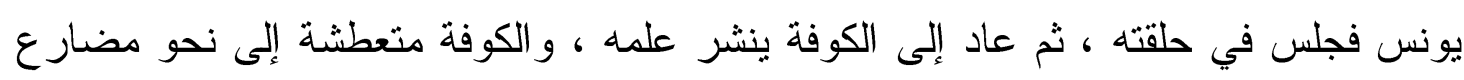

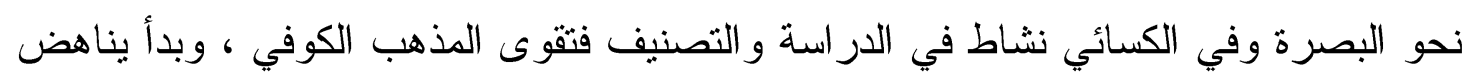

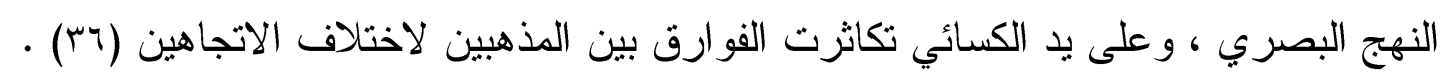

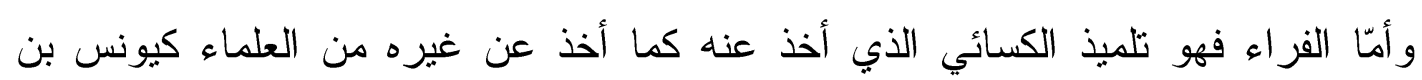

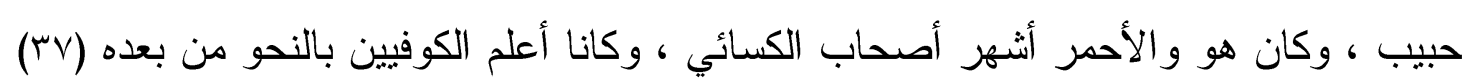

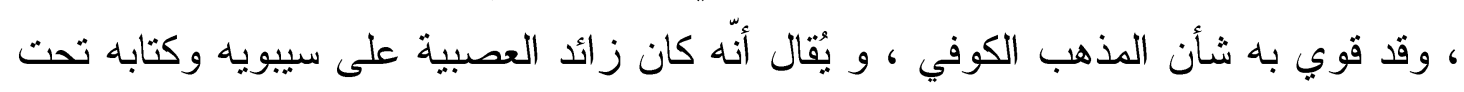

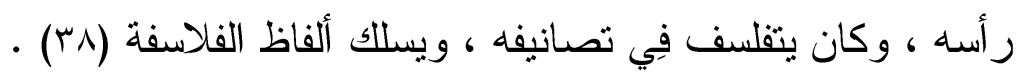

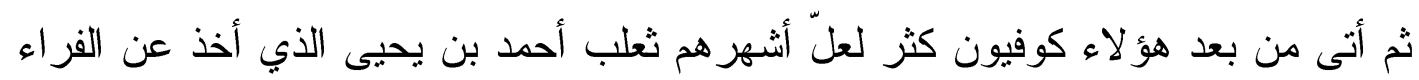

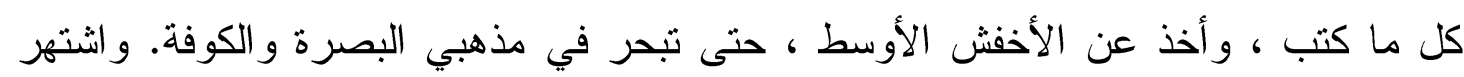

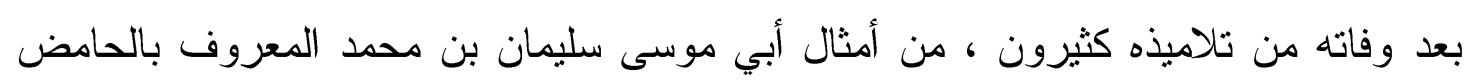

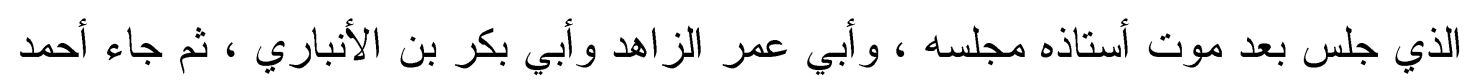

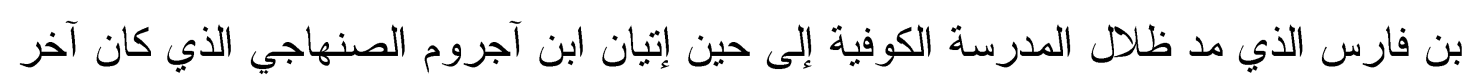

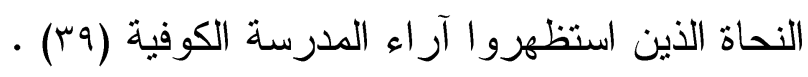


ويتسم المذهب الكوفي النحويّ بسمات تميّزه عن نهج البصريين أهمّها جانب الاتساع في الرواية بحيث يؤخذ من العرب جميعاً بدويهم وحضريهم ، فتفتح جميع الدروب و المسالك للأشعار و اللغات الشاذة ، كما يتميّز بالاتساع في القياس بحيث يقاس على الثاذ و النادر دون تقيّد بندرته وشذوذه ، إلى جانب ذلك نجد بعض المخالفة في بعض المصطلحات النحوية وما يتصل بها من العو امل لما أرساه نحاة البصرة ؛ ومن ذلك اصطلاح "الخلاف" وهو عامل بهل معنوي كانوا يجعلونه علة النصب في الظرف إذا وقع خبراً في مثل "محمد أمامك" ، أمّا البصريون فيجعلون الظرف متعلقاً بمحذوف خبر للمبتدأ السابق له ، ومن ذلك اصطلاح الصرف الذي جعله الفراء علة لنصب المفعول معه في حين ذهب جمهور البصريين إلى أنه منصوب بالفعل الذي قبله بتوسط الواو ، ومن ذلك اصطلاح الفعل الدائم ويقصدون به اسم الفاعل و المكني و الكناية ويقصدون به الضمير ، ويطلقون على البدل مصطلح الترجمة و على بلى بلى التمبيز التفسير و على الصفة النعت و على العطف بالحروف عطف النسق وغير ذلك (.ء) . ولكن الناظر في مصطلحات النحو يلحظ أنّ اصطلاحات الكوفين لم تجد السبيل للشهرة و الانتشار في النحو العربي ما عدا مصطلحي : النعت وعطف النسق ، وظلت المصطلحات البصرية هي السادة . ويوسم المذهب الكوفي بأنّ فيه مرونة في القياس وتركيب الجملة ؛ فهر مثلاً يُجوّزون صياغة "أفعل التفضيل" من البياض و السواد ، و الفصل بين المضاف و المضاف إليه بفاصل بإن

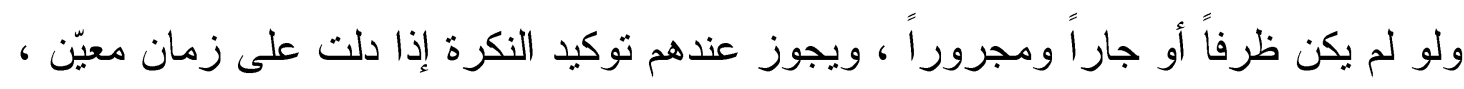
ويُبيحون إضـافة الثيء إلى نفسه إن اختلف اللفظ مثل "حقّ البقين" و "حبّ الحصبد" ، وغير ذلك (1)

ومع هذا فينبغي أن يعلم أنّ الاختلاف بين المدرستين لم يكن في الأصول والثوابت و إنما كان في جوانب فرعية كالعوامل التقديرية التي علّلوا بها الإعراب مع اتفاقهم في حكم الإعر اب نفسه . وقد نجد إماماً في هذا الفريق يساند رأي المدرسة الأخرى على نسق ما رُوي من مساندة الكسائي لآراء البصريين في بعض المسائل ، ومساندة المبرد البصري لآراء

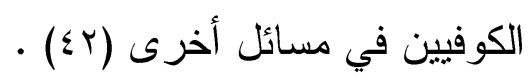
وبعد أن بانت آراء ومذاهب الفريقين البصري و الكوفي في مسائل النحو والصرف و اتضحث فُتحت الأبواب على مصاريعها للعلماء التابعين للاختيار من نهج المذهبين ما يرونه صواباً ؛ فكوّنوا ما عُرف بمدارس الانتخاب ، و أغلبهر كان يأخذ من رأي كلا الفريقين 
بنصيب مع الخروج إلى آراء خاصة أحياناً ، ومعظم هؤ لاء أو جلّهم كان ينسب إلى واحدة من

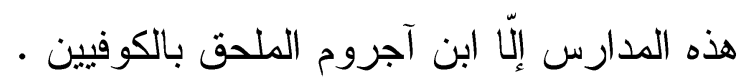

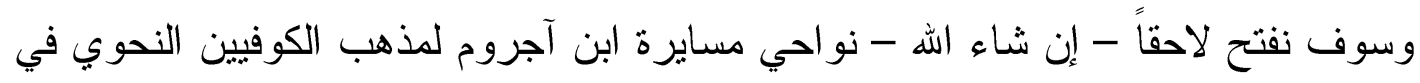

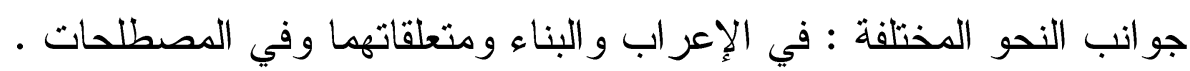

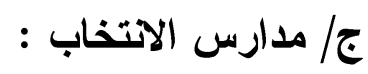

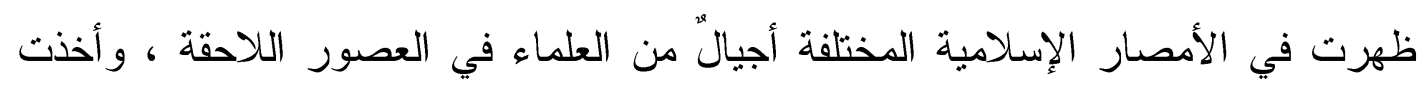

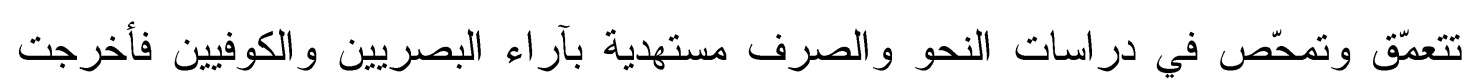

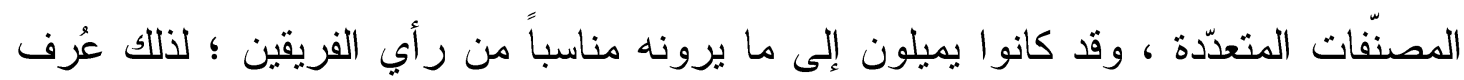

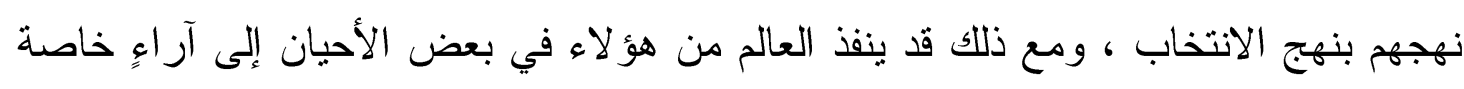

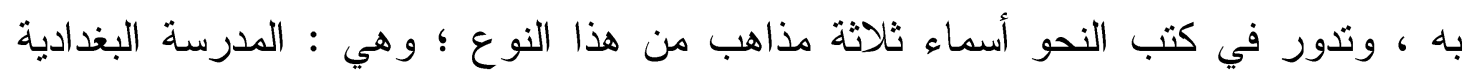

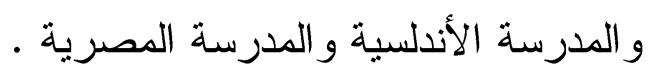

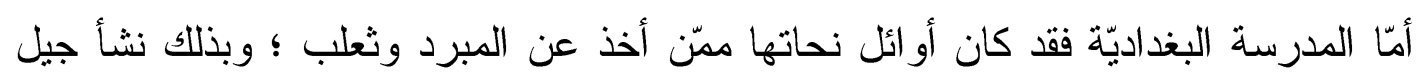

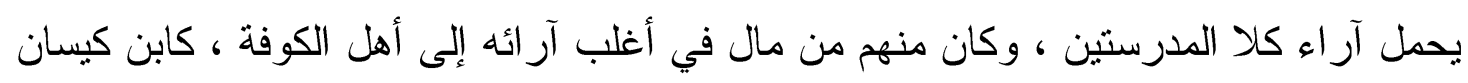

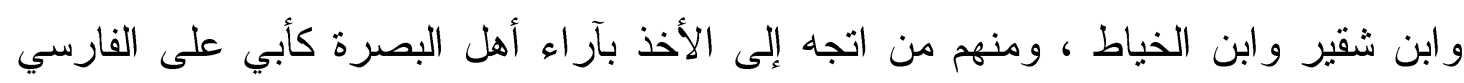

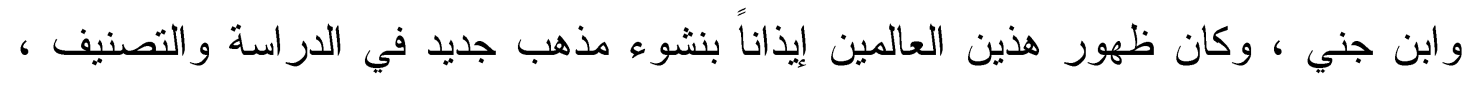

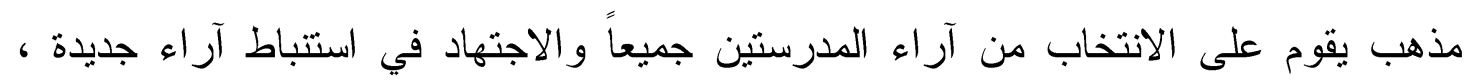

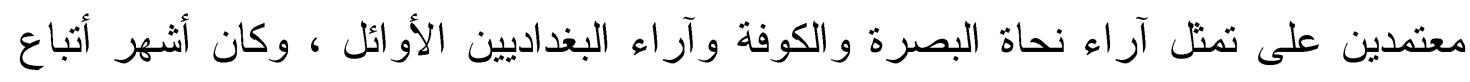

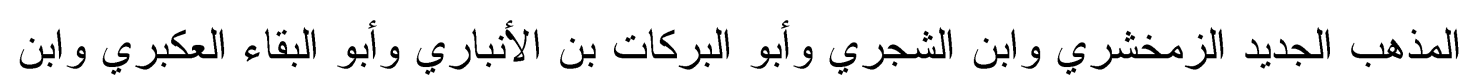

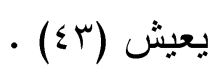
أمّّا المدرسة الأندلسية فابتدأت عناية علمائها بادئ الأمر بنحو الكوفة ؛ فكان أولهم جودي

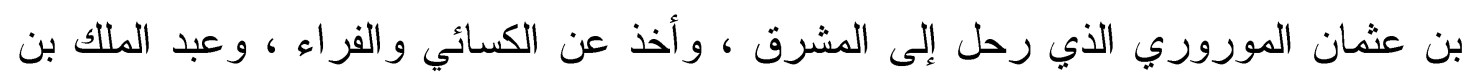

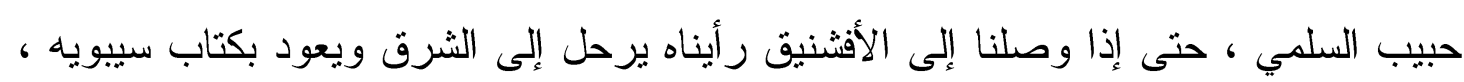

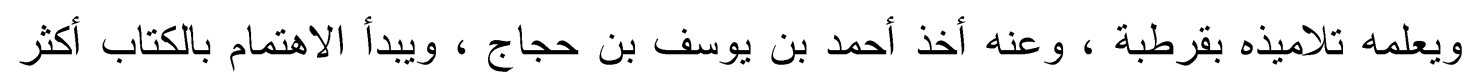

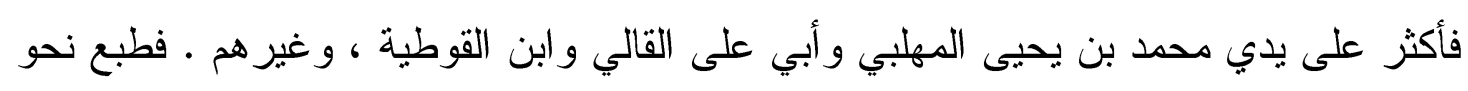

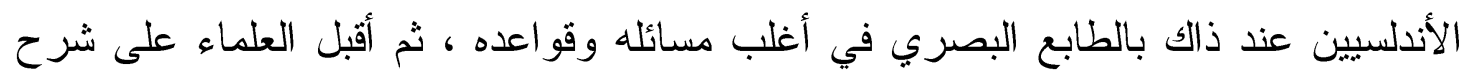

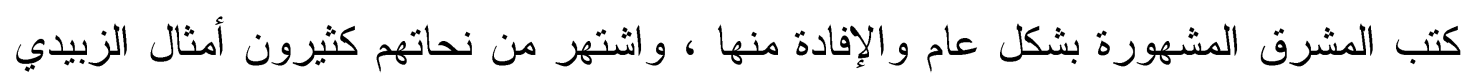

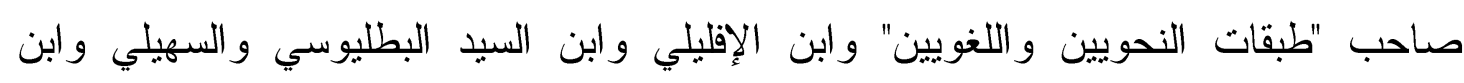

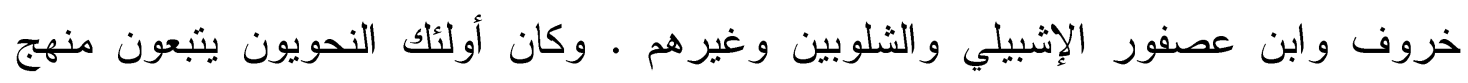


الانتقاء من آراء نحاة البصرة و الكوفة ، وربما ذهبوا إلى الفارسي وابن جني ، ولكنه كانوا

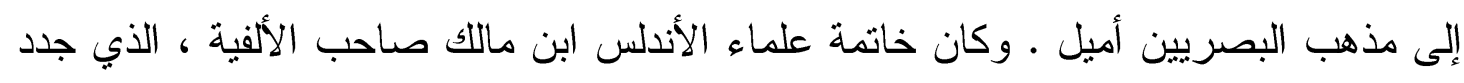

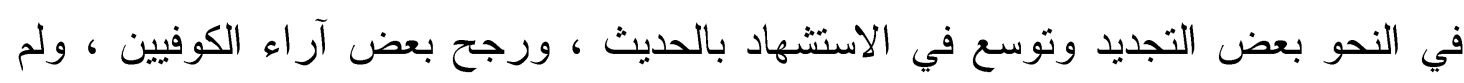

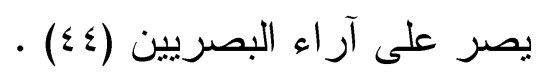

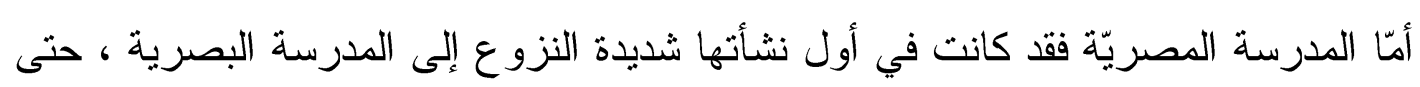

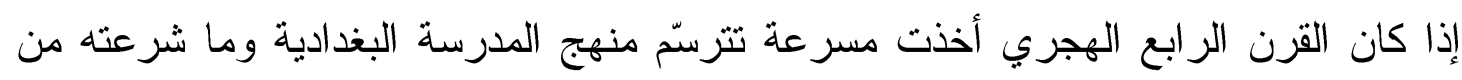

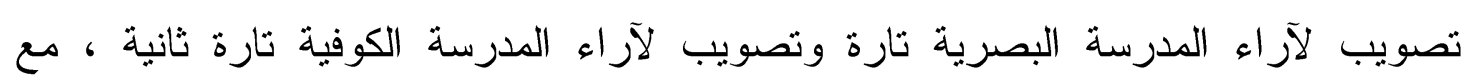

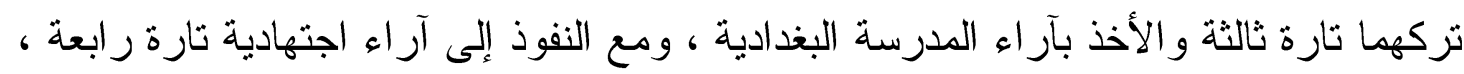
على نحو ما يصور ذلك من بعض الوجوه أبو جعفر النحاس والحوفي وابن بابشاذ وابن بري.

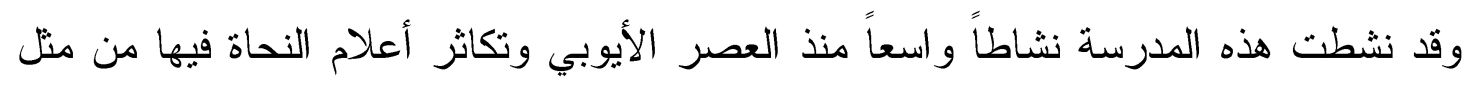

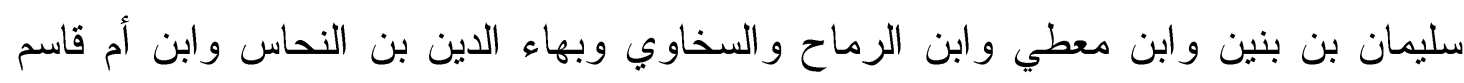

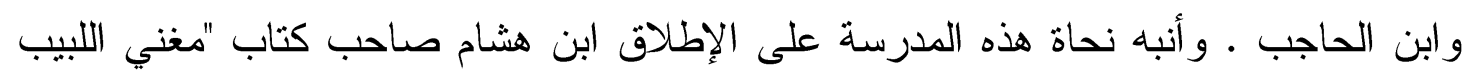

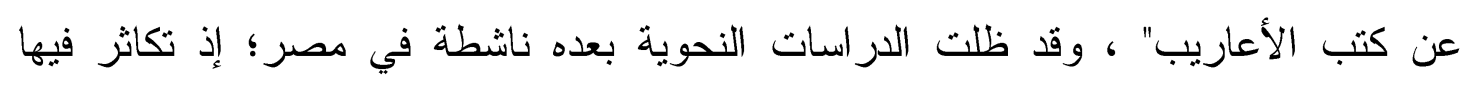

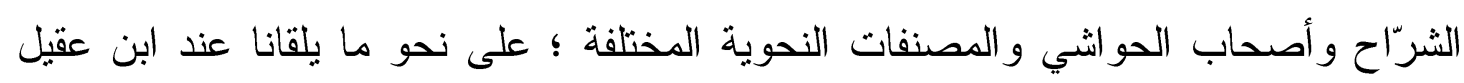

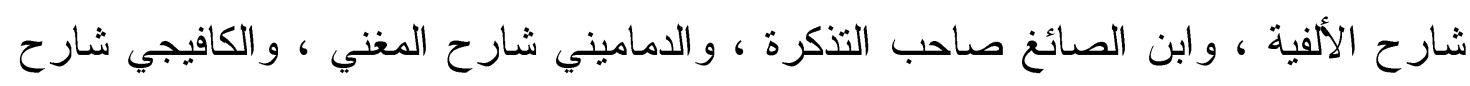

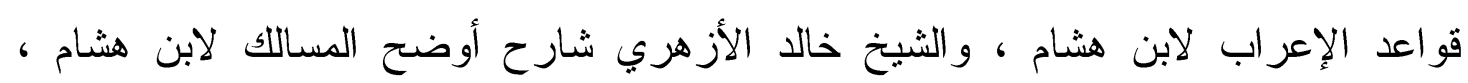

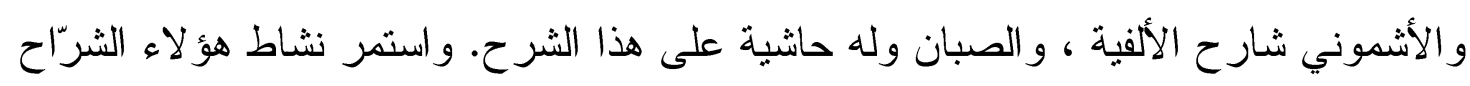

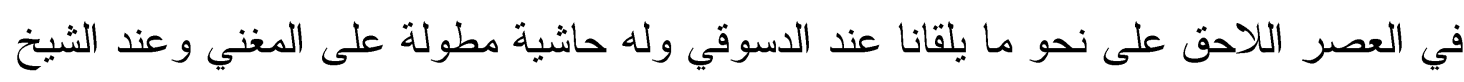

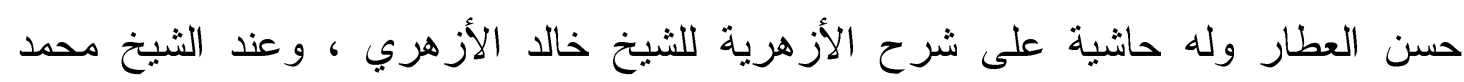

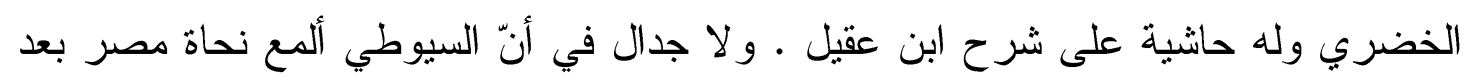

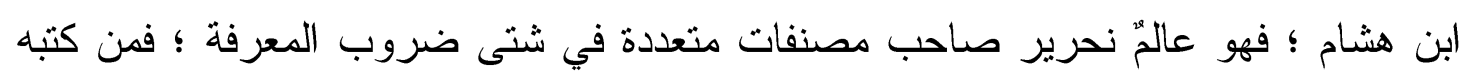

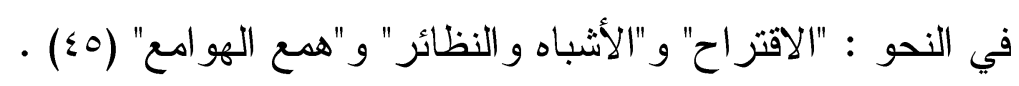

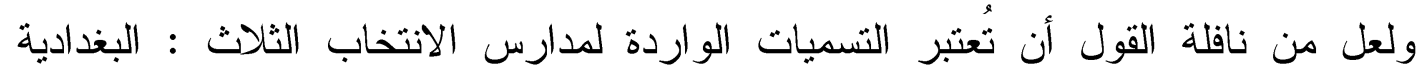
والأندلسيّة والمصرية تسميات مناطق أكثر من كونها تسميات تحمل رؤى نحويّة محددّة

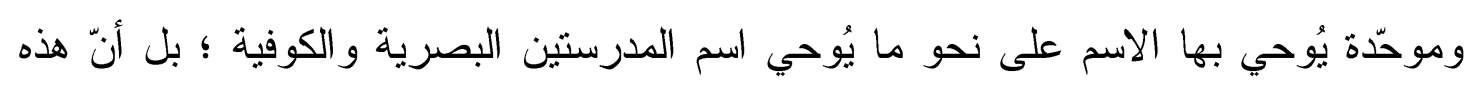
المدارس تكاد تتو افق في نهج واحدٍ وهو منهج الاختيار للمناسب من آراء آلاء المدرستين الأوليين

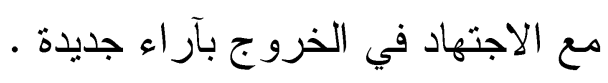


ولم يكن من حظّ ابن آجروم أن ينسب إلى واحدة من مدارس الانتخاب هذه رغم تأخرّه

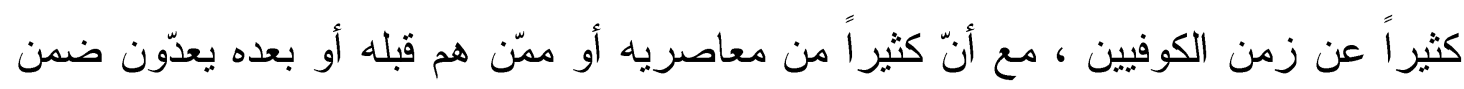

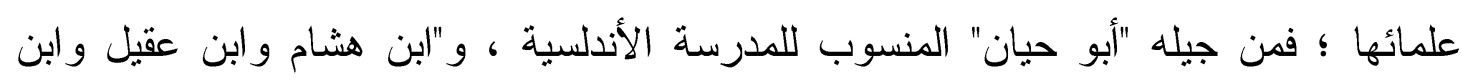

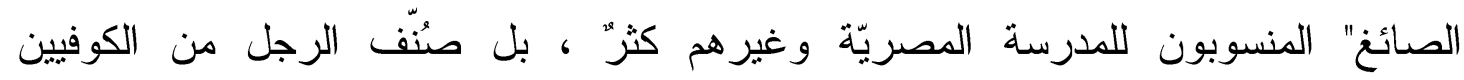

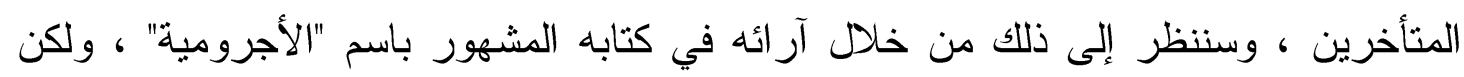

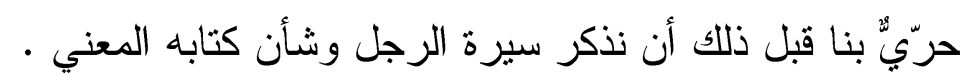

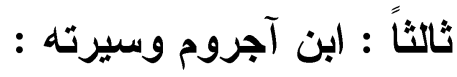

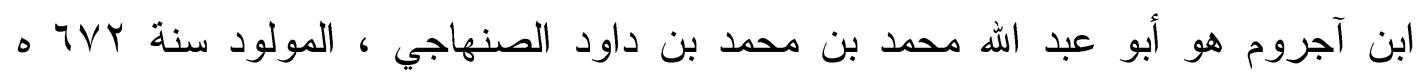

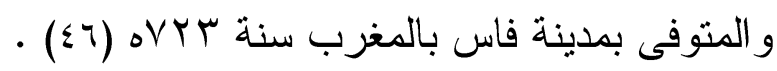
و آجُرُوّم بفتح الهمزة المددودة وضم الجيم و الر اء المشدّدة ، ومعنى الاسم بلغة البربر الفقير

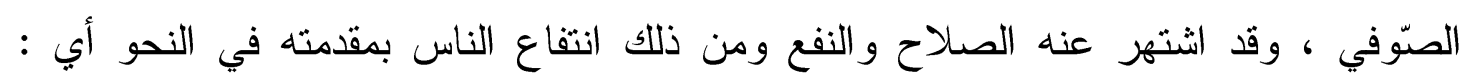

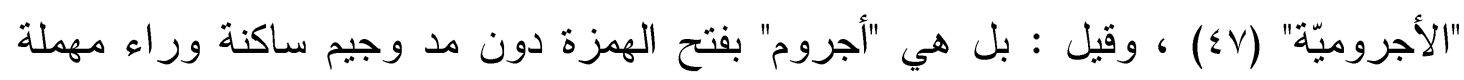

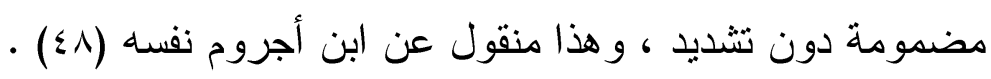

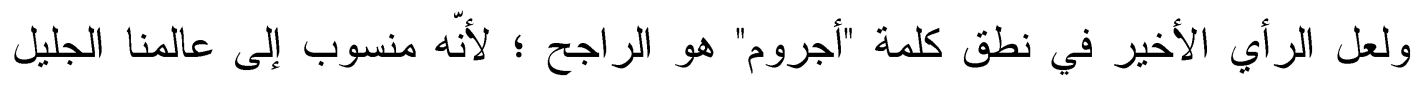

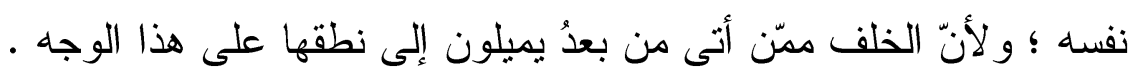

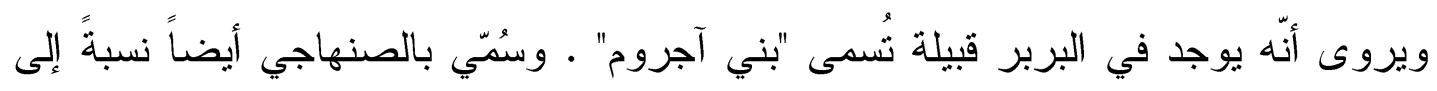

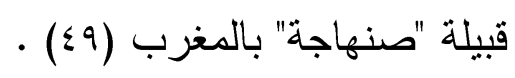

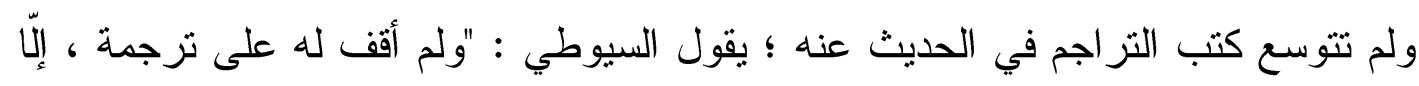

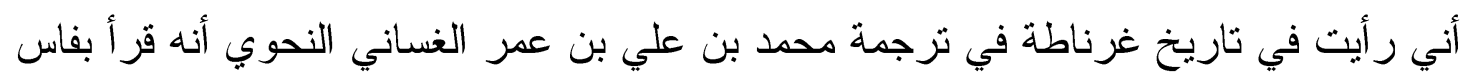

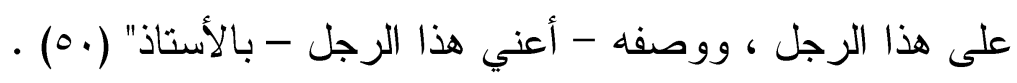

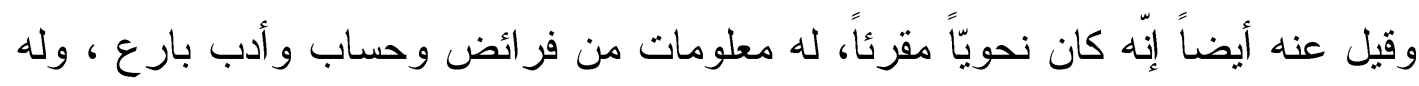

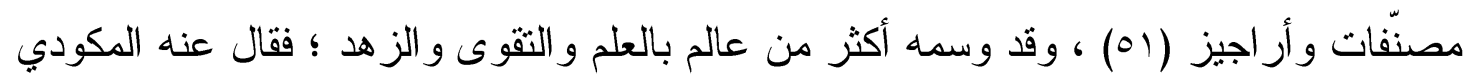

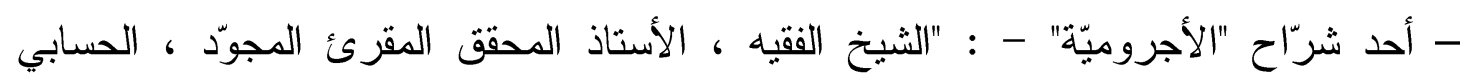
الفرضي ، نجيب دهرهوفريد عصره" (ror) .

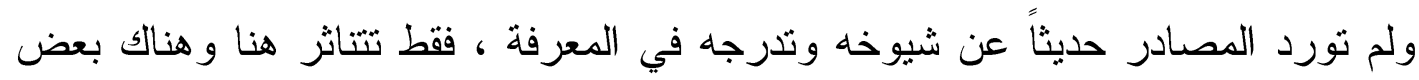

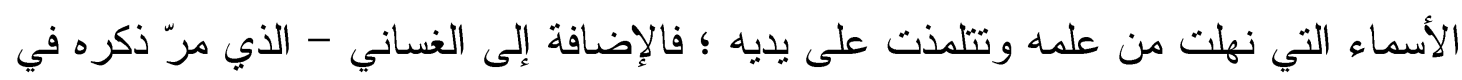

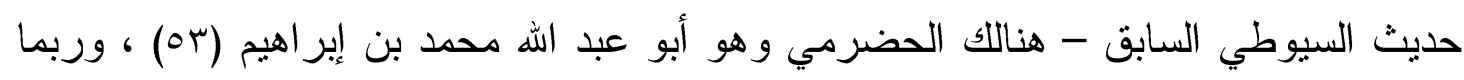

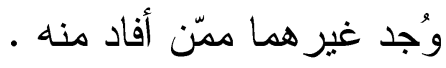




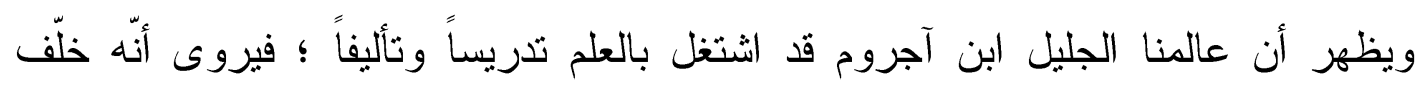

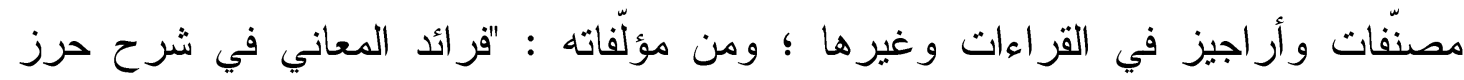

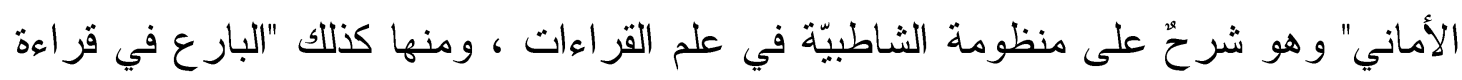

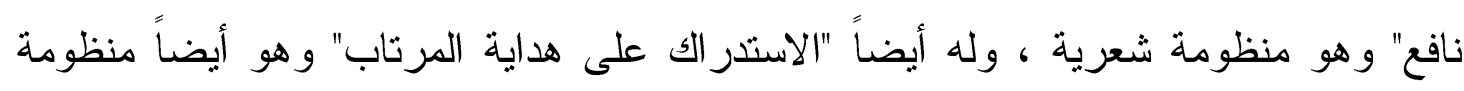

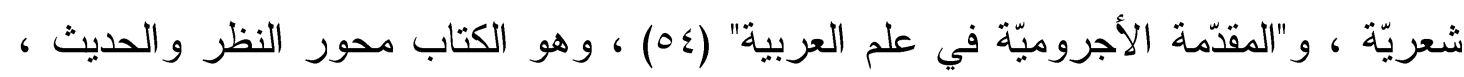

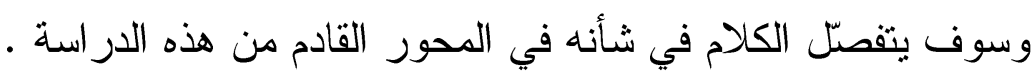

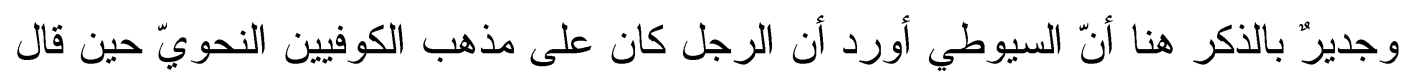

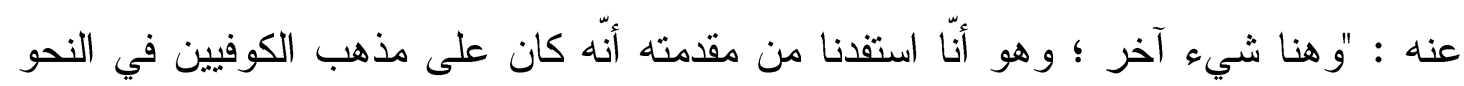

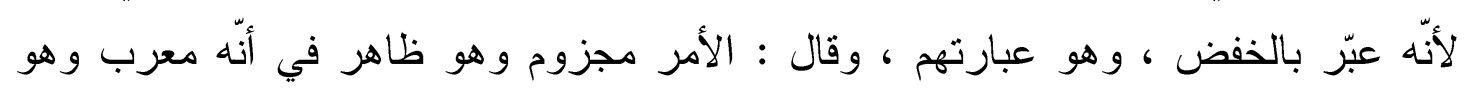

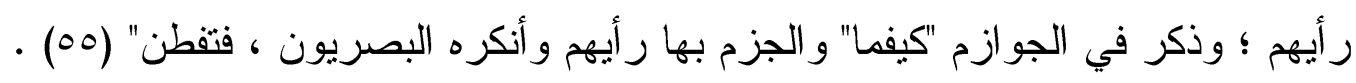

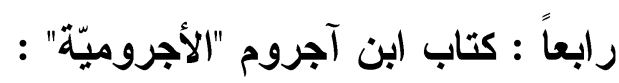

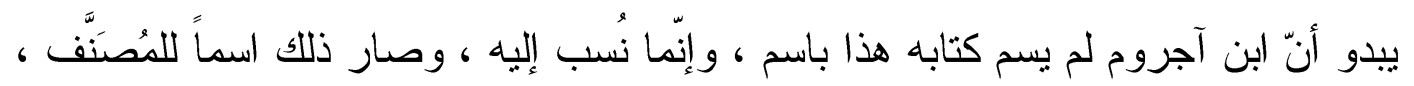

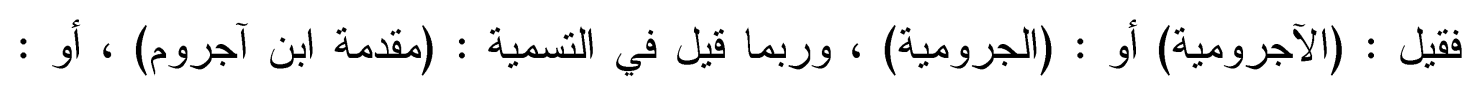

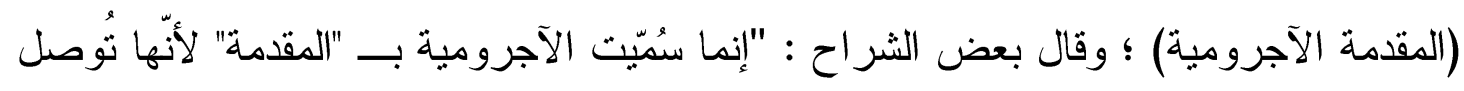

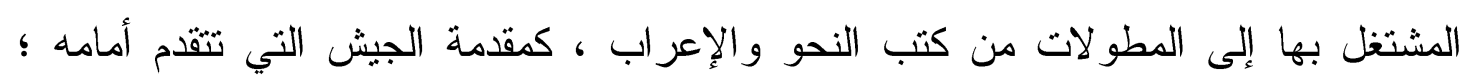

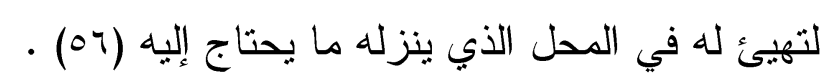

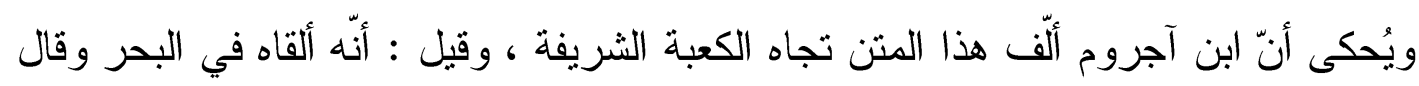

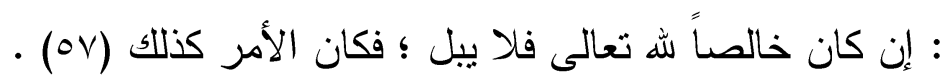

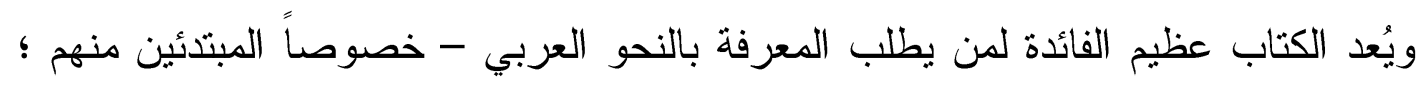

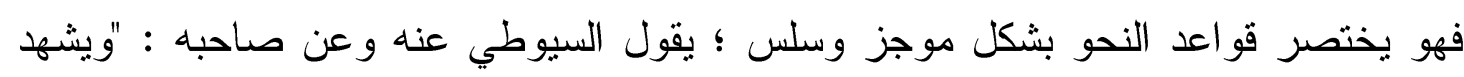

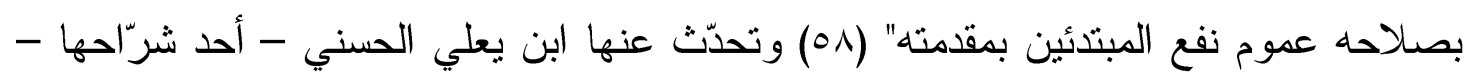

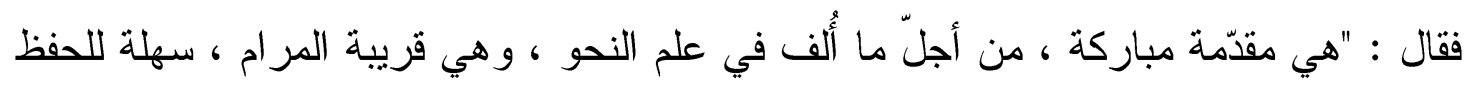

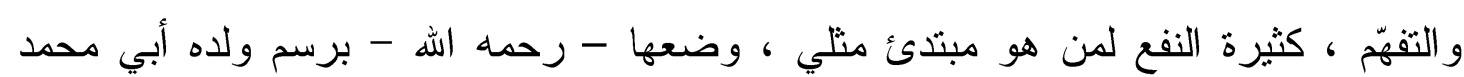

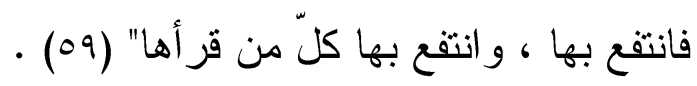
ولعل الاختصار الذي عليه "مثن الأجروميّة" كان أحد الأسباب التي أدّت إلى كثرة شرّاحها

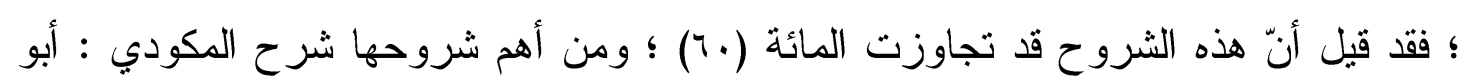

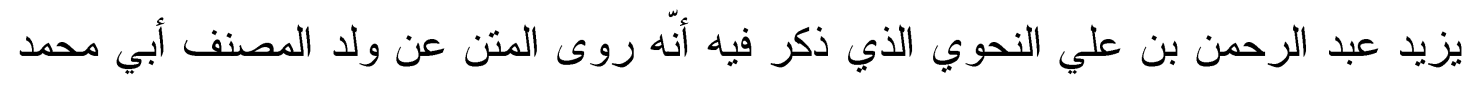

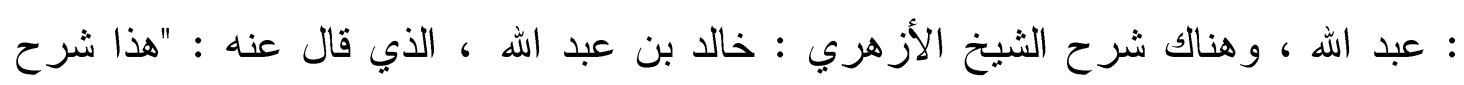


ينتفع به المبتدئ و لا يحتاج إلبه المنتهي" ، ومنها أيضاً شرح الثنواني : أبي بكر بن إسماعيل

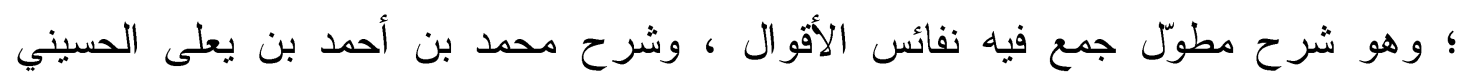

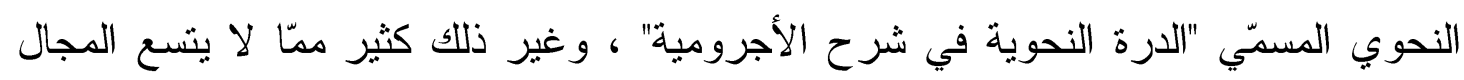

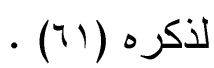
وقد اشتخل عدد من العلماء بعمل عدد من الحواشي على بعض هذه الشروح ؛ ومن ذللك :

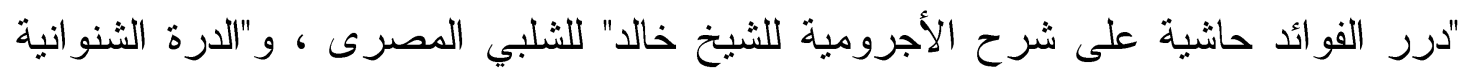

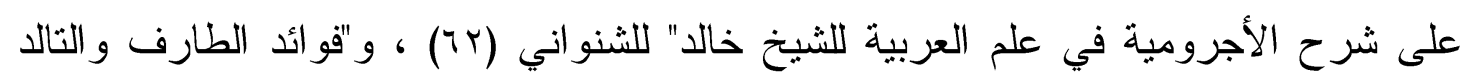
على شرح الآجرومية للشيخ خالد" للسيوطي ، و "تثويق الخلان على شرح الآجرومية للسية للسيد

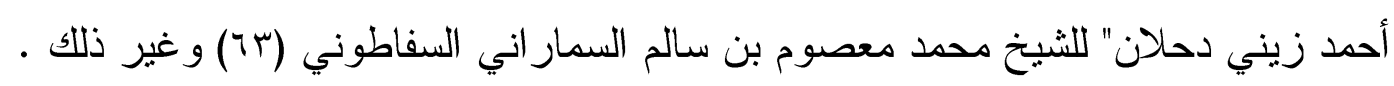

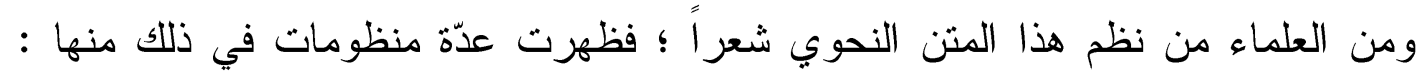

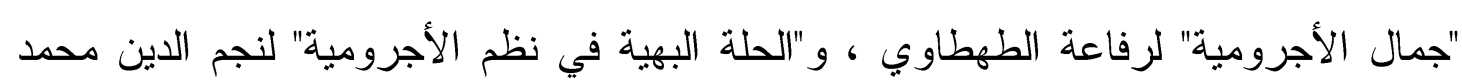

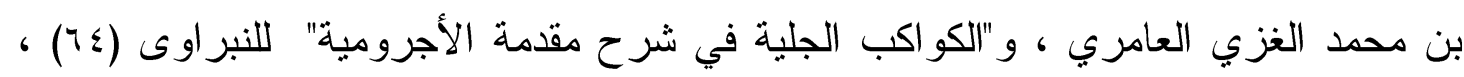
وغير ها .

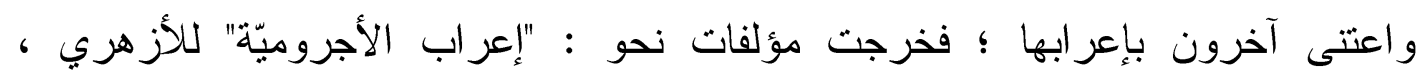

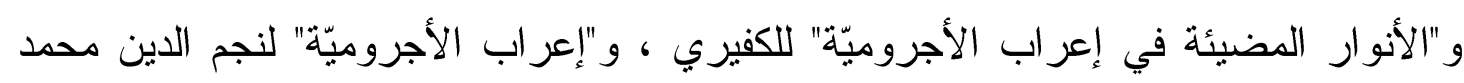

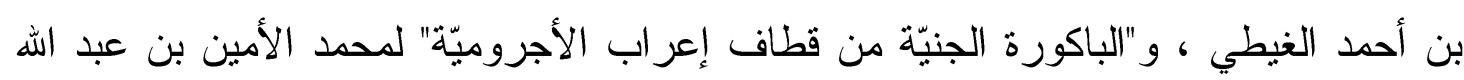

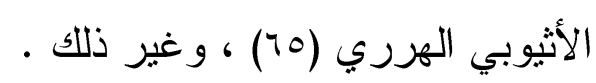
و هكذا عظُم شأن الأجروميّة في كل العصور التي تلت تأليفها ؛ فاهتم العلماء بها وتلقِّوها شرحاً وتوضيحاً ونظماً و إعر اباً وعمل حواش ، و ، وبقي لنا أن ندلف بعد تقصيل الحديث في هذا

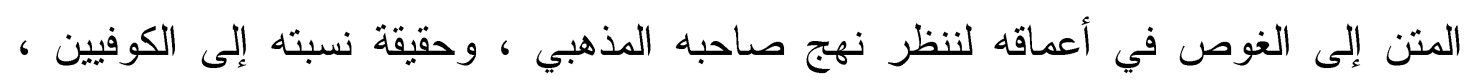
و استظهاره لآر ائهر.

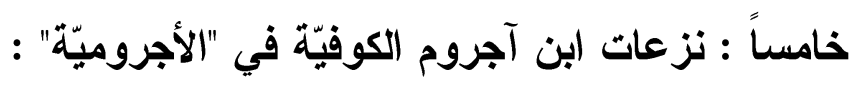

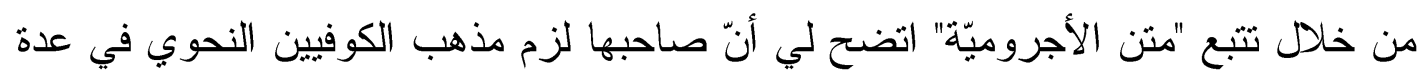

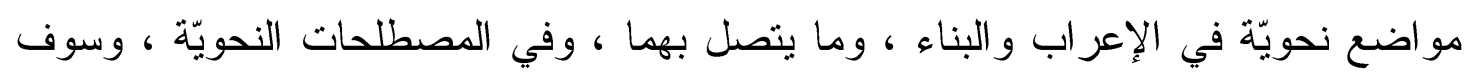

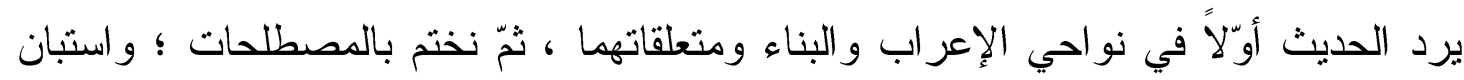

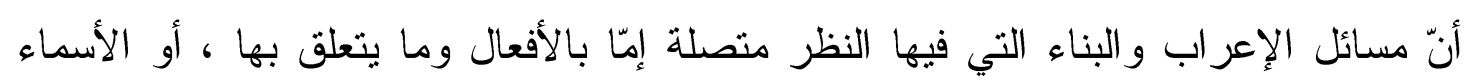

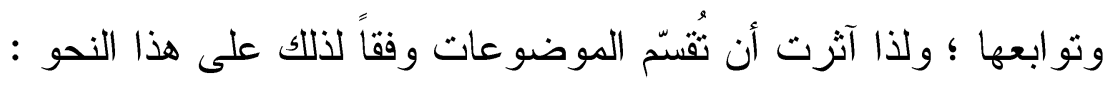




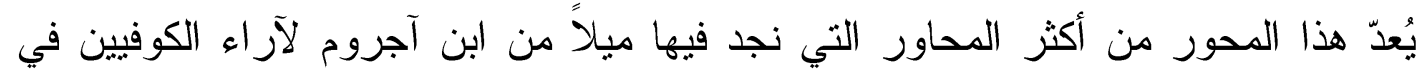

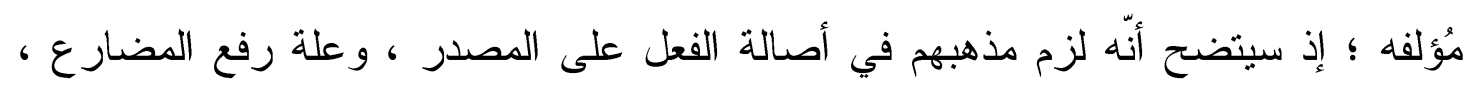

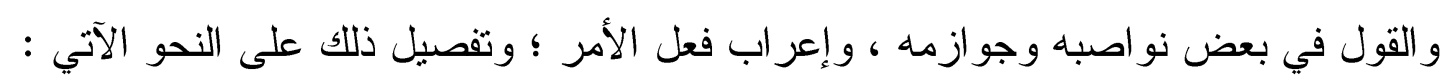

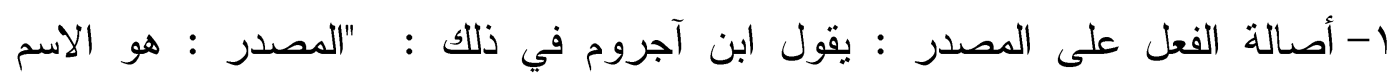

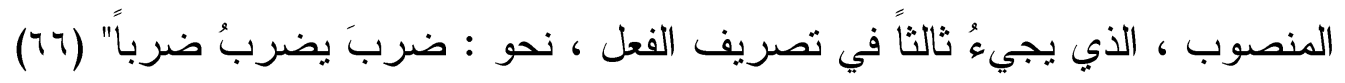

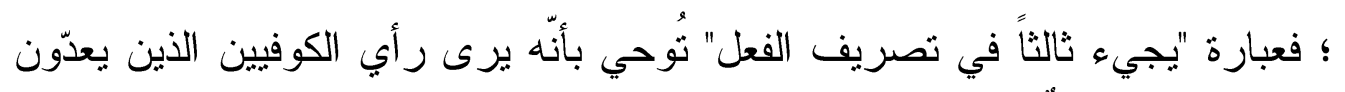

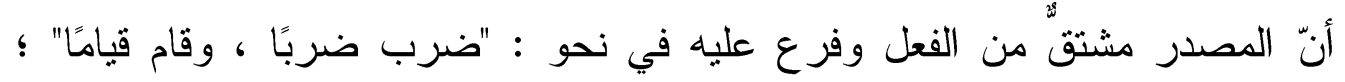

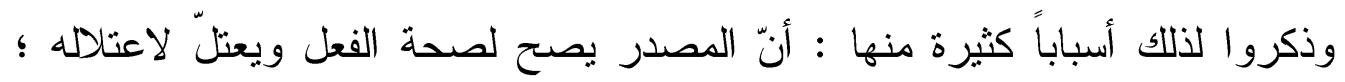

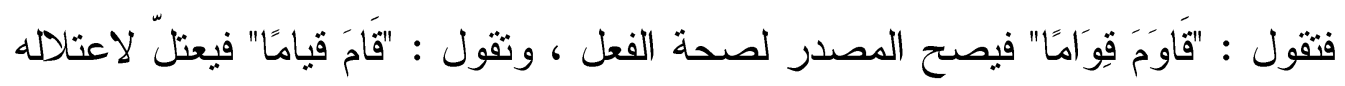

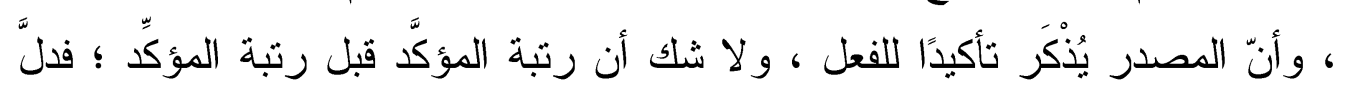

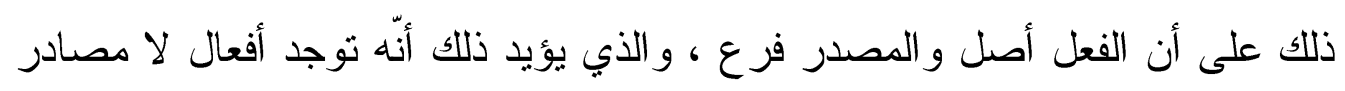

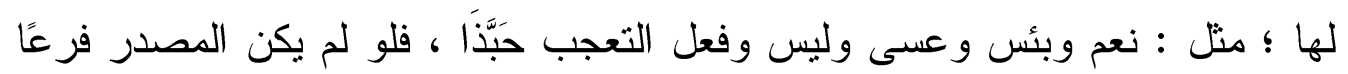

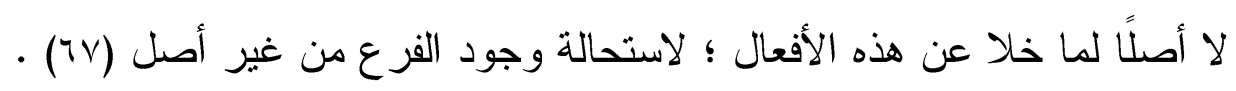

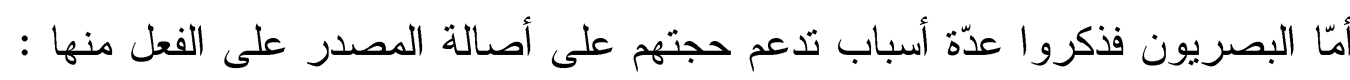

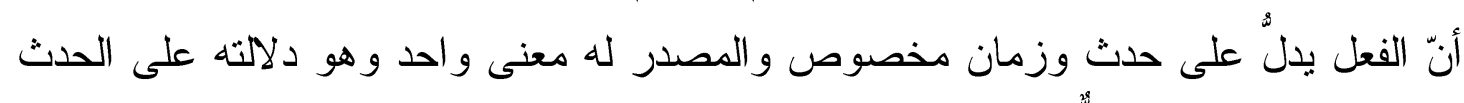

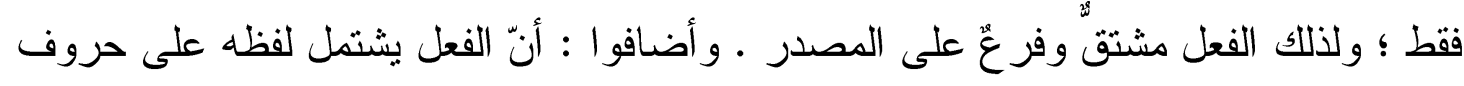

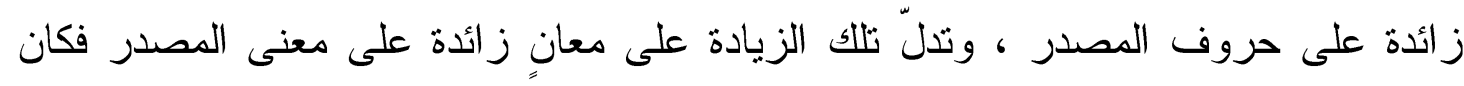

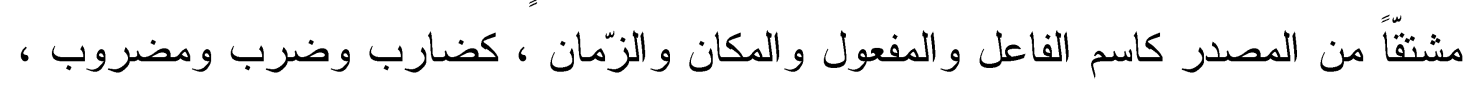

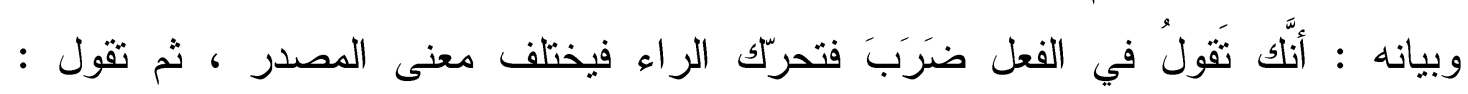

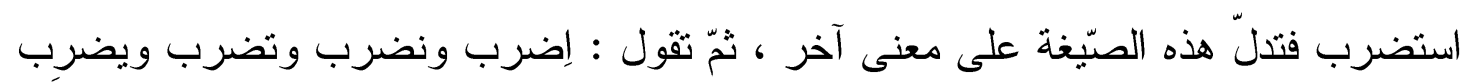

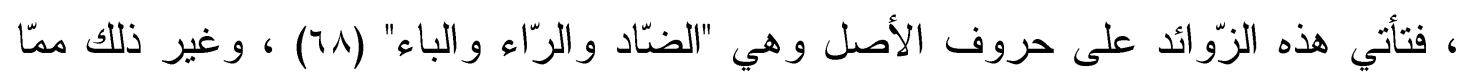
أوردوه . تقاني هذه

ولعل تقديم ابن آجروم - في كتابه - الأفعال وما يتصل بها في الذكر على الأسماء وما

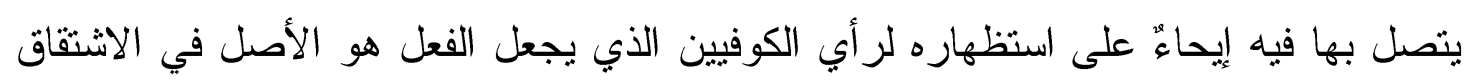

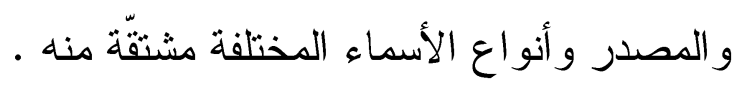

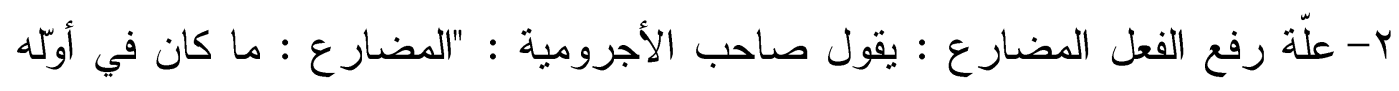

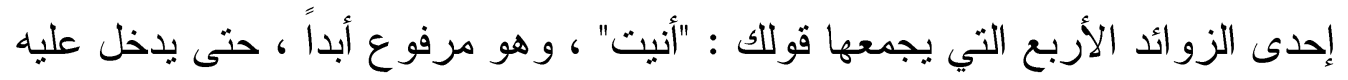

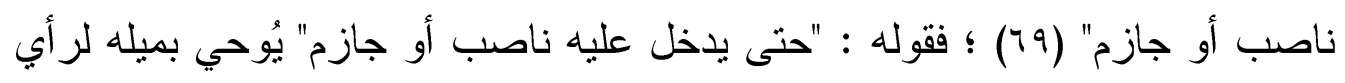


أكثر الكوفيين الذي يقول : إنّ علة رفع المضارع هي تعريته من العوامل الناصبة

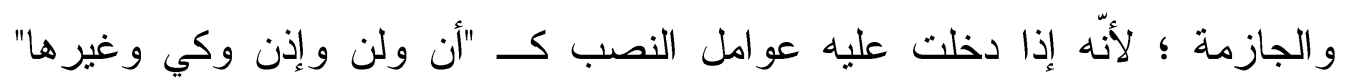

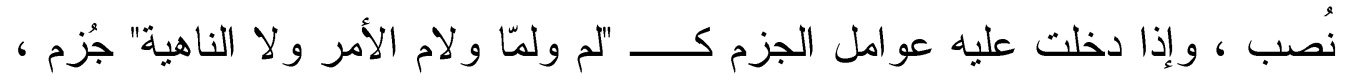

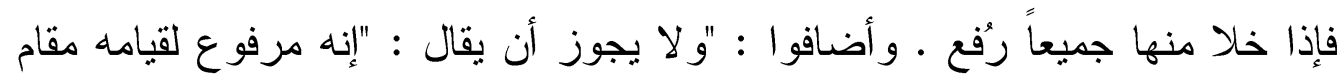

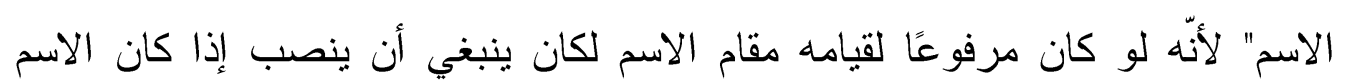

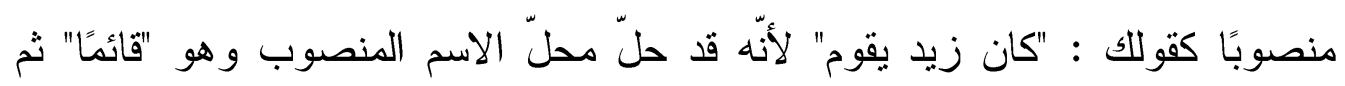

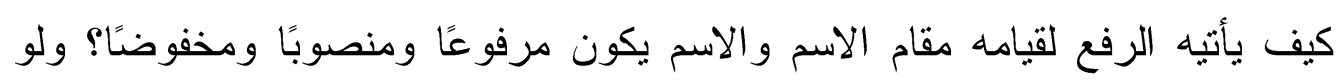

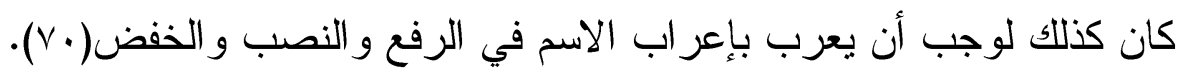

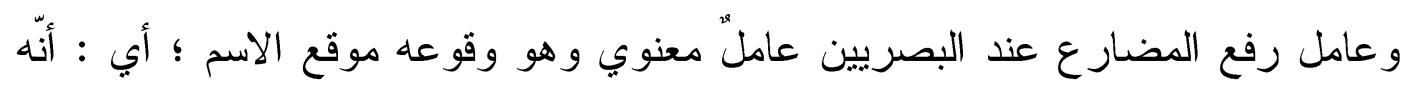

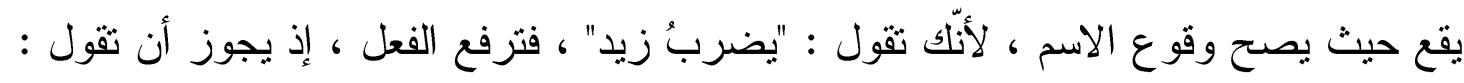

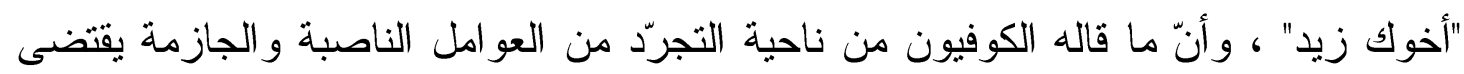

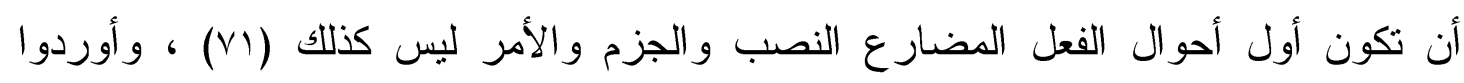
حججاً غير هذه .

وقد مال ابن مالك إلى رأي الكوفيين في هذه المسألة ؛ حيث قال في ألفيته (Vr) :

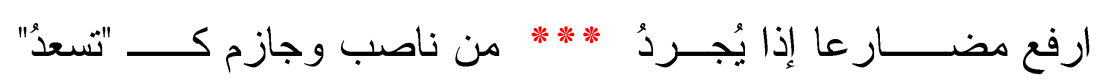

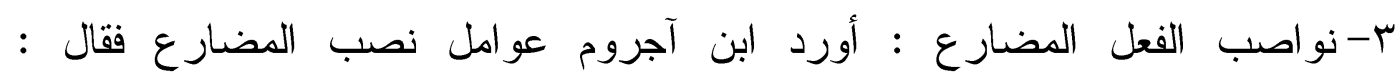

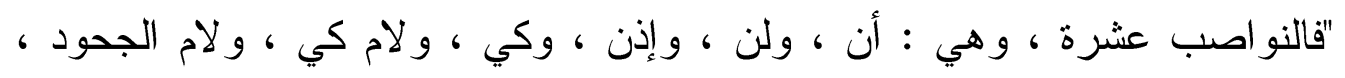

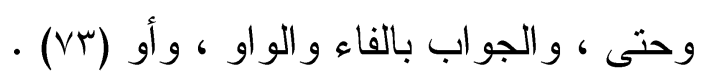

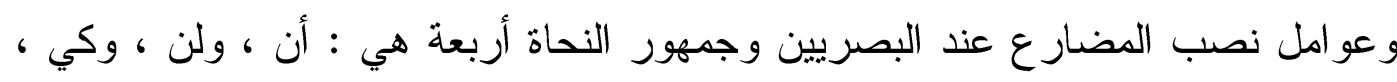

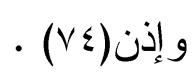

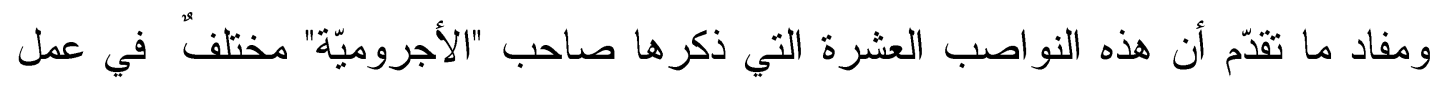

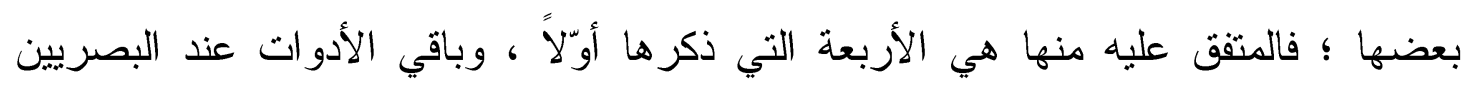

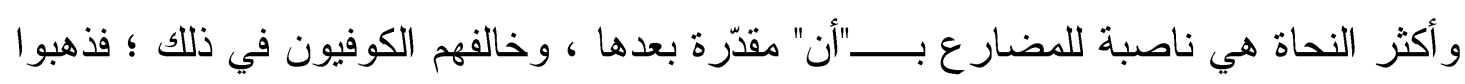

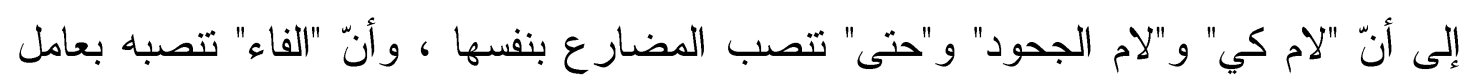

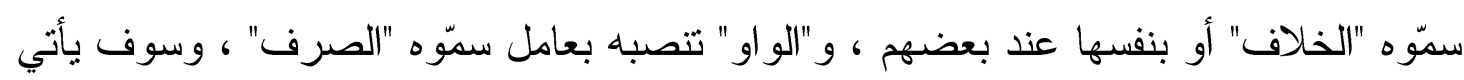

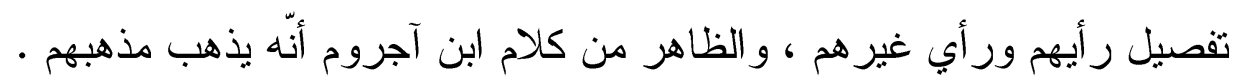

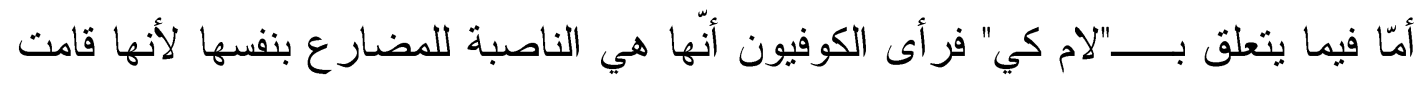

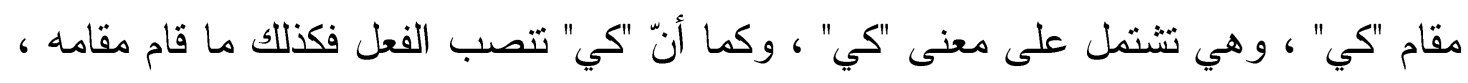


ومنهم من قال : إنما نصبت الفعل لأنها تفيد معنى الشرط ، فأشبهت "إن" المخففة الشرطية ،

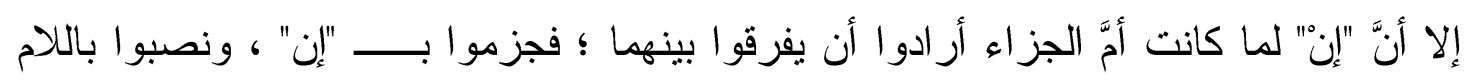

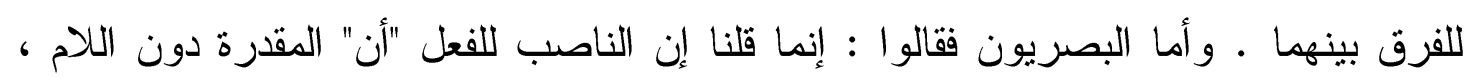
وذلك لأنّ اللام من عو امل الأسماء ، وعو امل الأسماء لا يجوز أن تكون عو امل للأفعال ؛

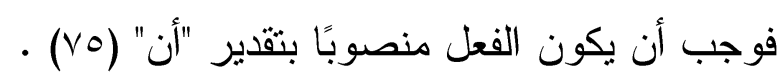
و احتجّ الكوفيون لعمل "لام الجحود" النصب في الفعل المضارع الحجج نفسها التي ذكروها

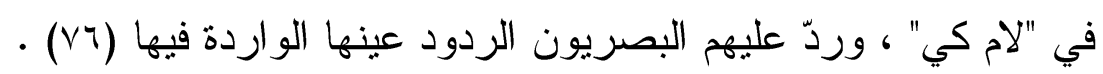
ويرى معظم الكوفيين كذلك أنّ "حتى" هي الناصبة للفعل المضارع دون تقدير "أنه" ؛ فهي إمّا أن تكون بمعنى "كي" كقوللك : "أطع الله حتى يدخلك الجنة" أي : كي يدخلك الجنة ، و إمّا

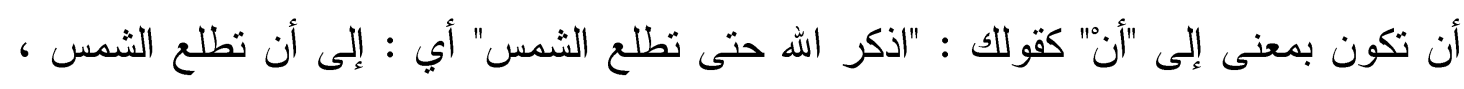
فإن كانت بمعنى "كي" فقد قامت مقام "كي" ، و "كي" تتصب فكذلك ما قام مقامها ، و إن كانت بمعنى "إلى أن" فقد قامت مقام "أن" ، و"أن" تتصب فكذلك ما قام مقامها (VV) . وقد ردّ البصريون ما ذهب إليه نحاة الكوفة بأنّ "حتىى" من العو امل التي تجرّ الأسماء ، فلا

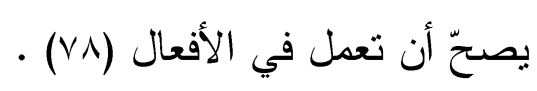
أسّا نصب المضار ع بعد حروف العطف "الفاء" و"الواو" و"أو" فزعم الكوفيون أنّ النصب

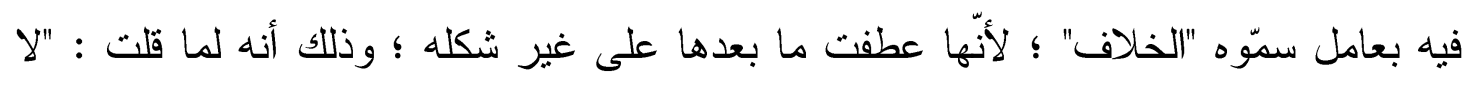

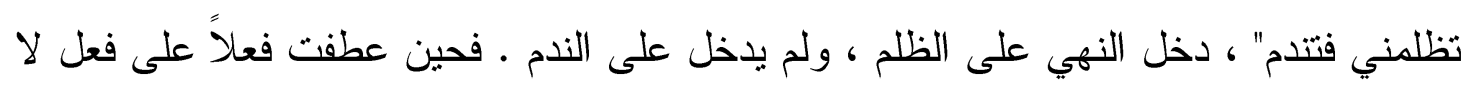
يشاكله في معناه ، و لا يدخل عليه حرف النهي كما دخل على الذي قبله ، استحق النصب بالخلاف ، كما استحق ذلك الاسم المعطوف على ما لا يشاكله في قولهم : "لو تزكت و الأسد لأكلك" ، و المقصد في هذا الأخير هو نصب المفعول معه بعد "واو المعيّة" يكون أيضاً بعامل فئ فئ

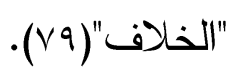

وزعم أبو عمر الجرمي من البصريين أنّ حروف العطف هذه في هذا الوضع هي الناصبة

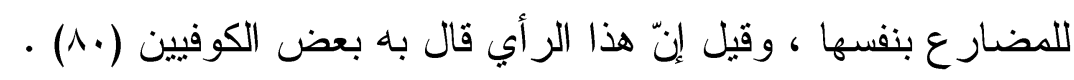

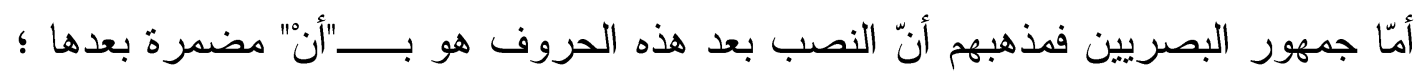
لأنّها حروف عطف ، وحروف العطف تذخل على الأسماء و الأفعال . وكل حرف يدخل على الأسماء و الأفعال لا يعمل في أحدهما ، فلذلك وجب أن تُقدر "أنْ" بعدها ليصح نصب الأبع الفعل 
ويمكن أن نخلص ممّا تقدّم أنّ صاحب "الأجروميّة" كان يقول- إجمالاً - - برأي الكوفيين

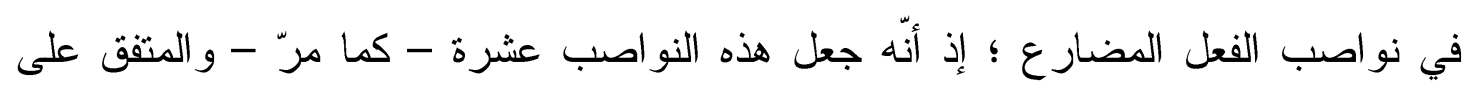

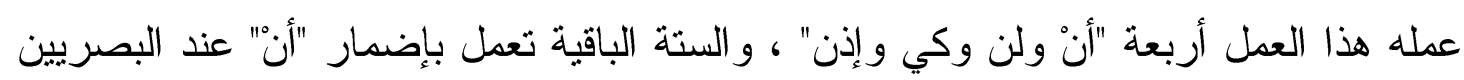

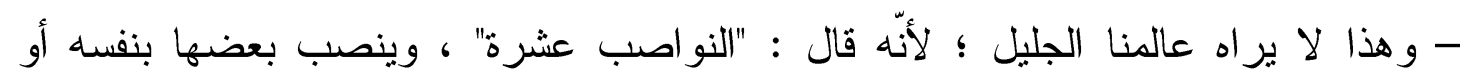

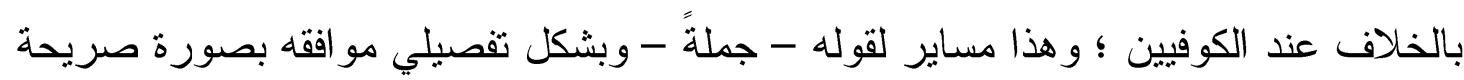

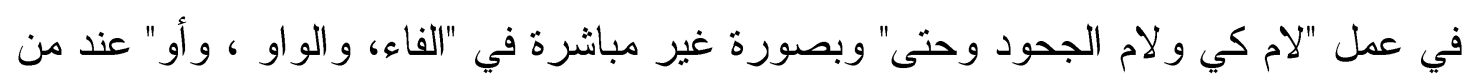

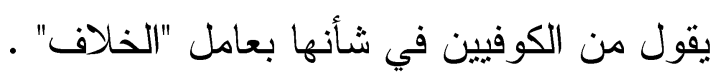

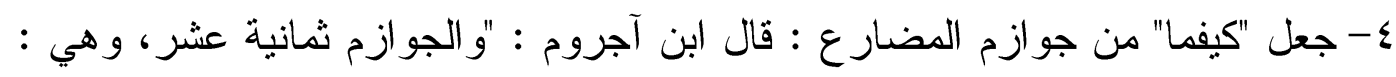

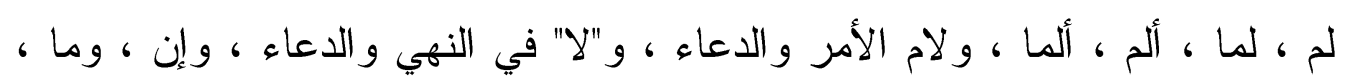

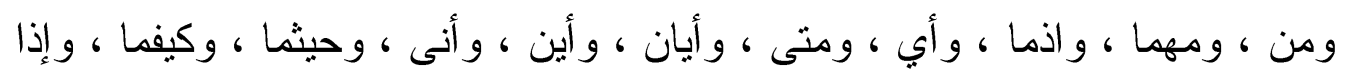

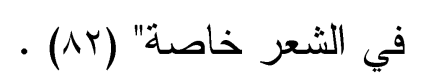

ويرمز إيراد صاحب الأجروميّة "كيفما" ضمن أدوات الثرط التي يُجزم بعدها المضارع

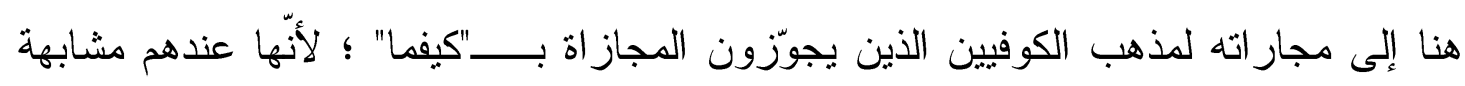

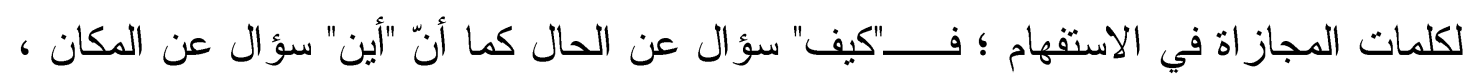

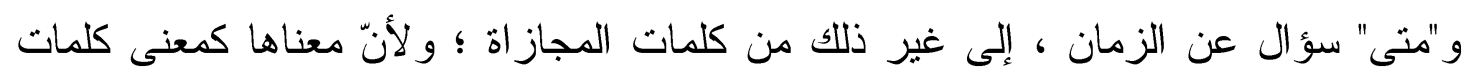

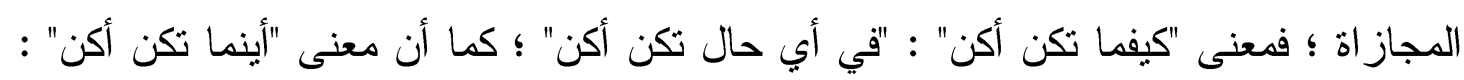

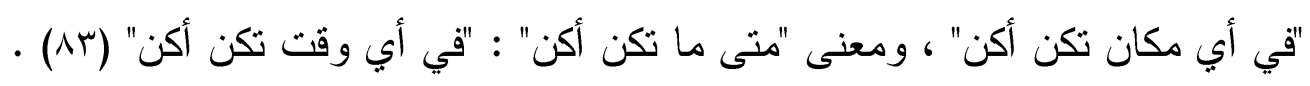

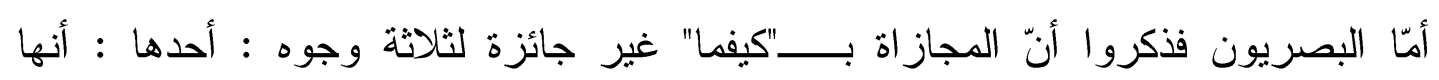

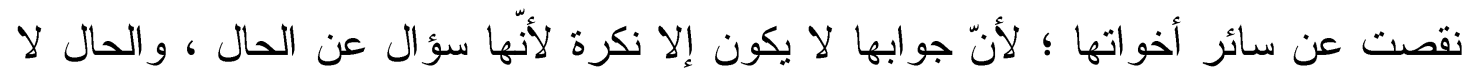

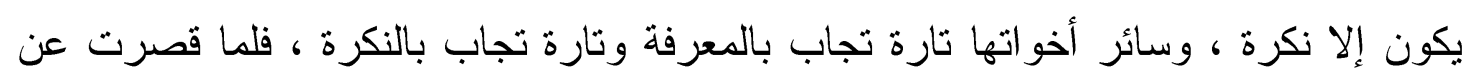

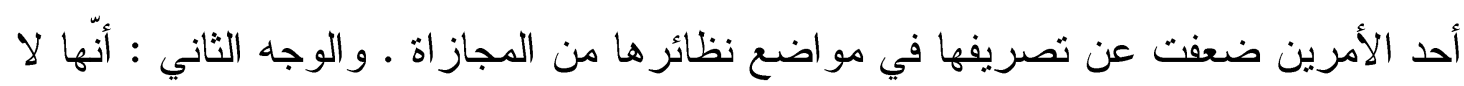

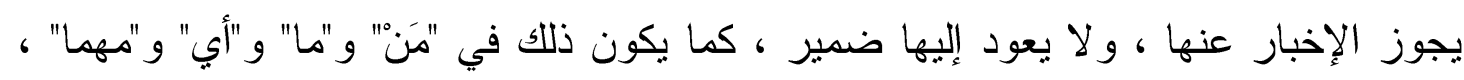

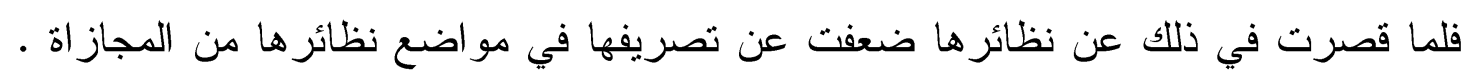

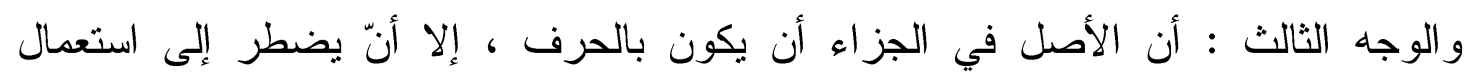

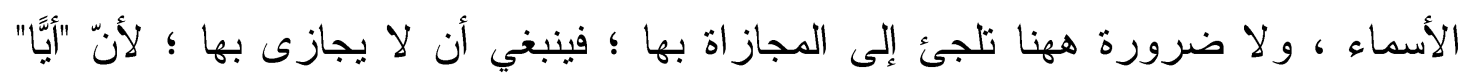


ويبدو أنّ الوجه الثاني الذي ذكره البصريون هنا ضعيف الحجة ؛ لأنّه توجد أدوات استقهام

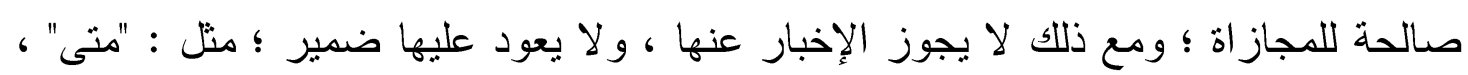

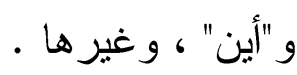

0- إعراب فعل الأمر : تحدّث صاحب الأجروميّة عن الأفعال فقال : "الأفعال ثلاثة :

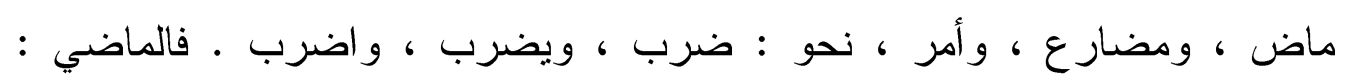

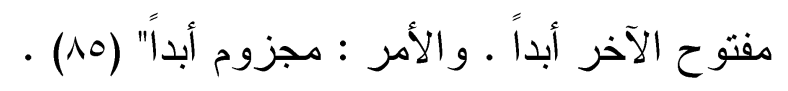

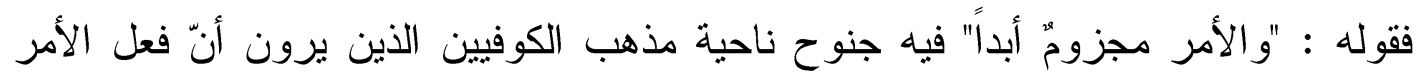

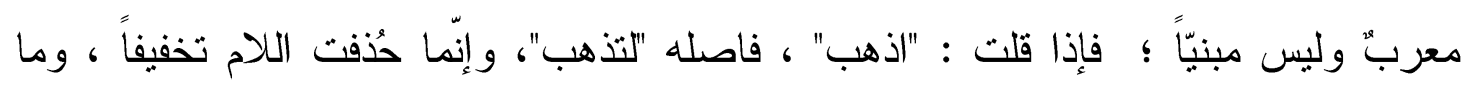

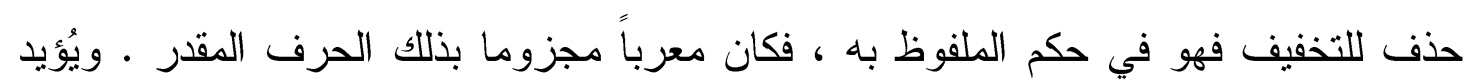

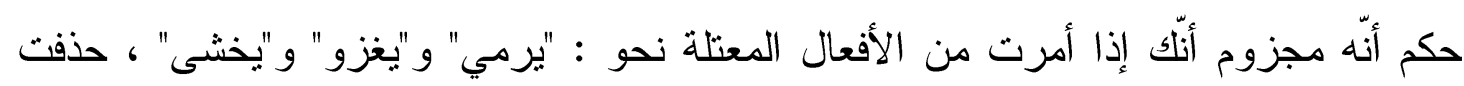

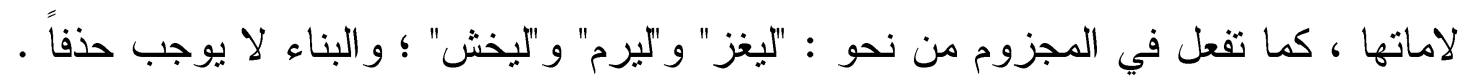

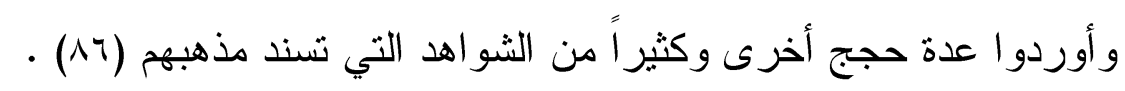

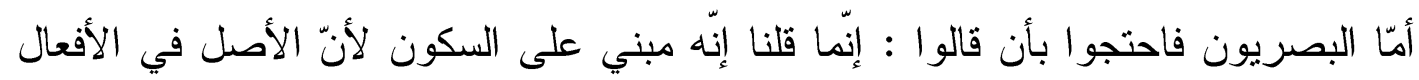

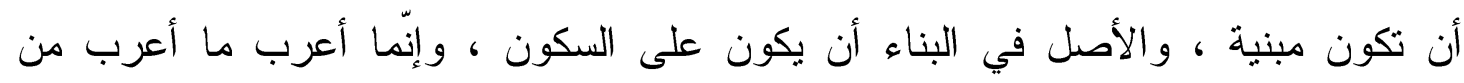

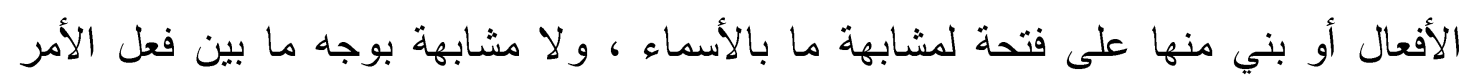

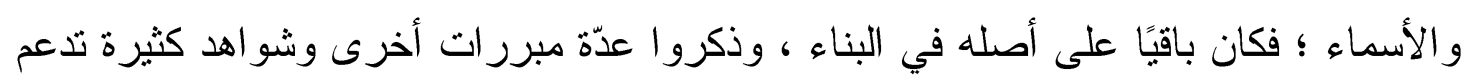

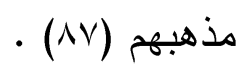
و الذي عليه جمهور النحويين هو البناء لفعل الأمر ؛ إلّا أنّ عالمنا الجليل ابن آجروم مال

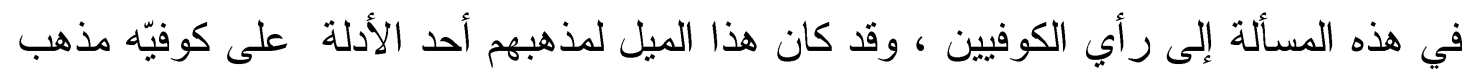

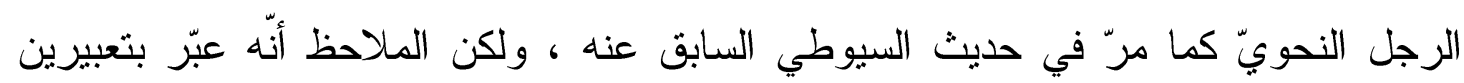

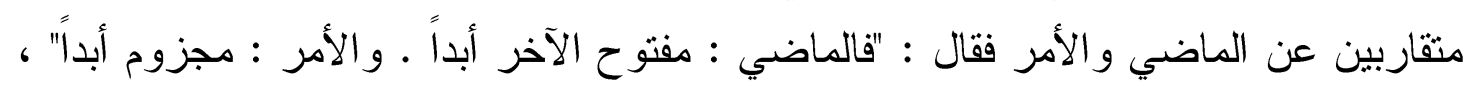

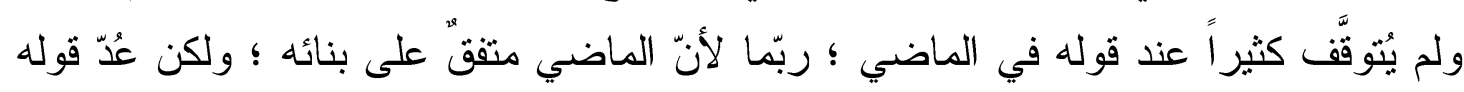

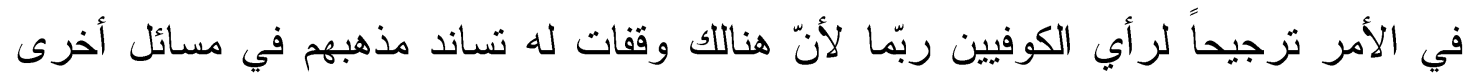
غير هذه المسألة . 


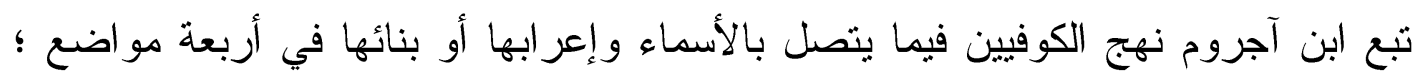

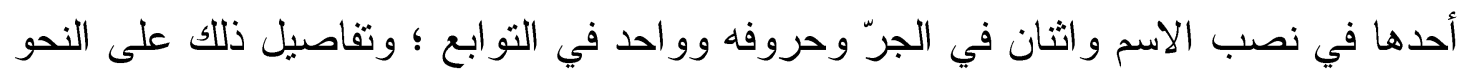
الآتي :

1-نصب اسم "لا" النافية للجنس للمفرد النكرة : ورد في "الأجروميّة" قول صاحبها : "

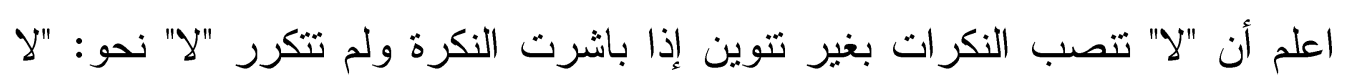

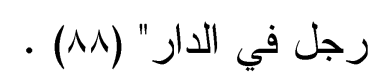

و هذا الذي ذكره ابن آجروم ممانل لرأي الكوفيين الذين يذهبون إلى أنّ اسم "لا" النافية

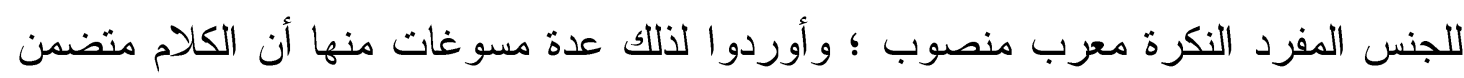

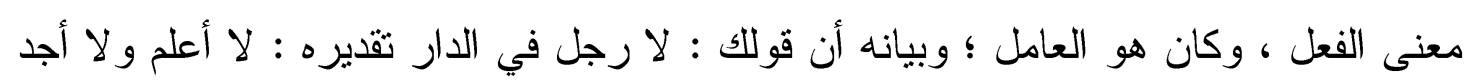

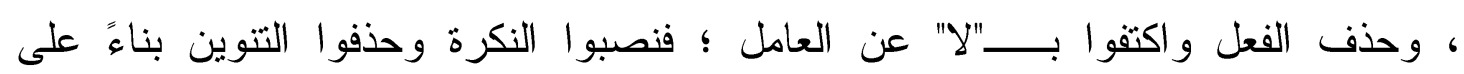

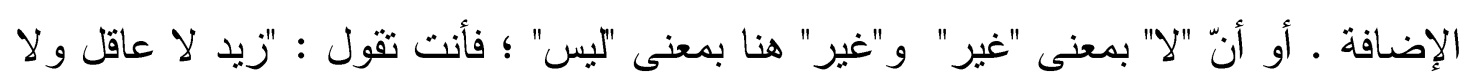

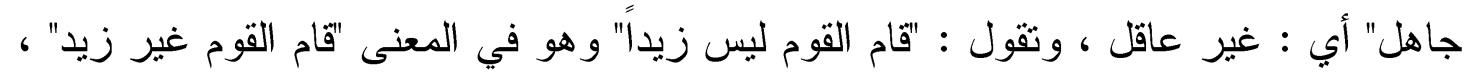

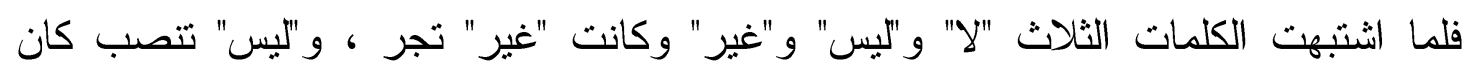

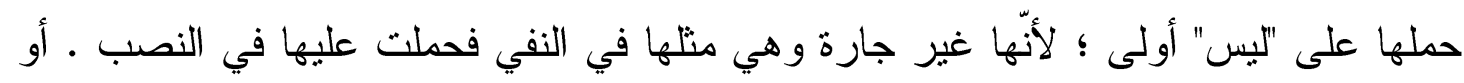

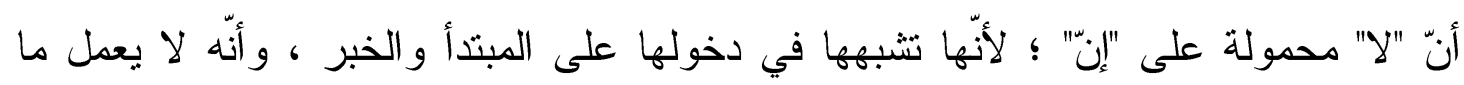

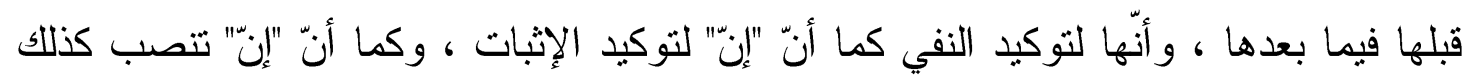
- (19) " ل"

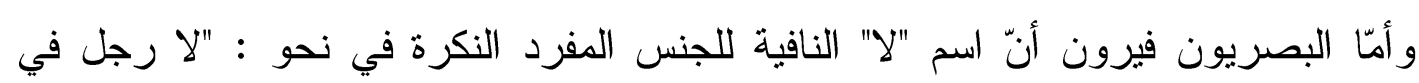

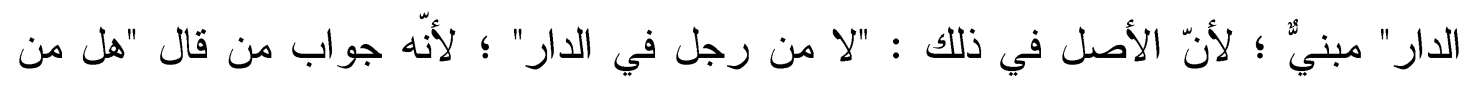

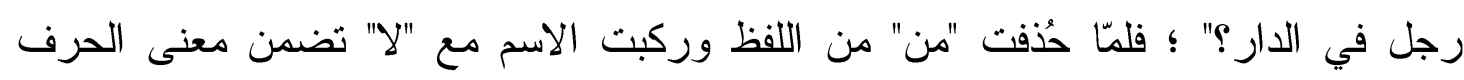

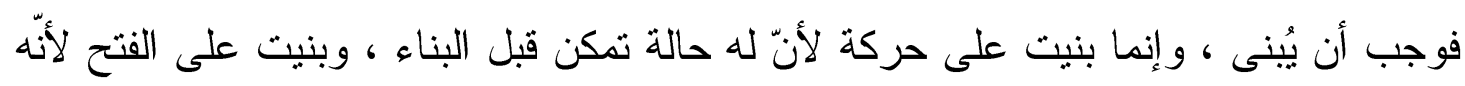
أخف الحركات (9. (9).

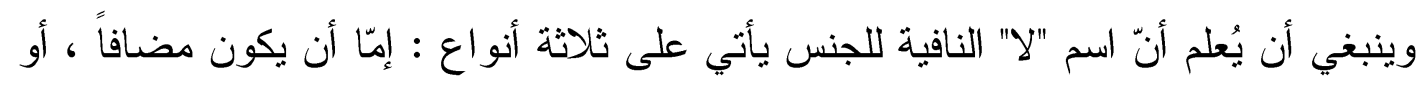

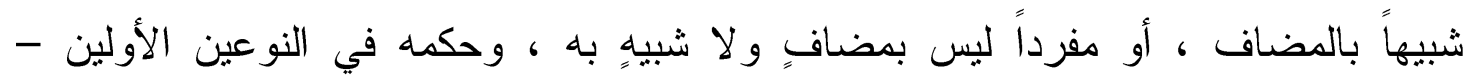

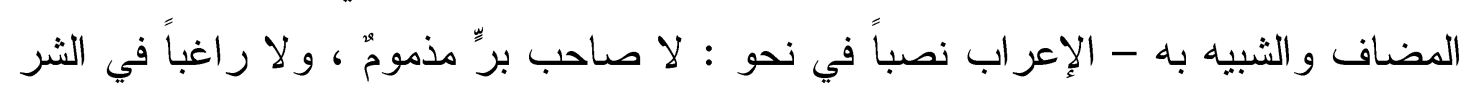

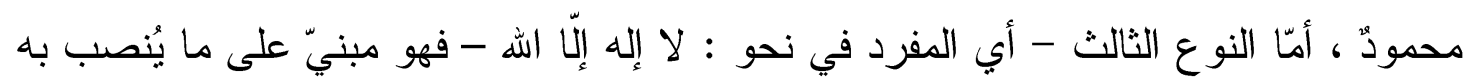

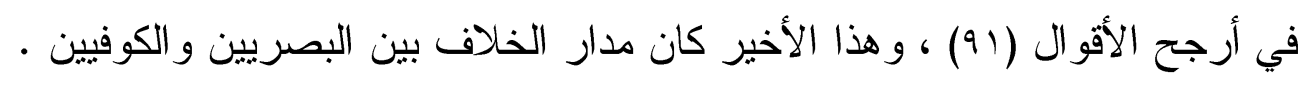


r- الجرّ بواو "ربّ" : قال صاحب الأجروميّة في باب المخفوضات "المجرورات" : " فأما

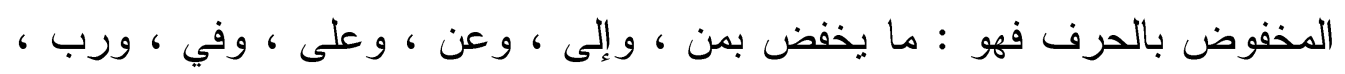

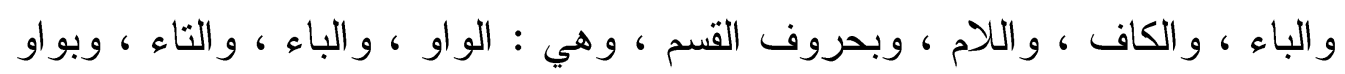

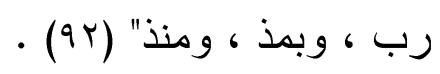

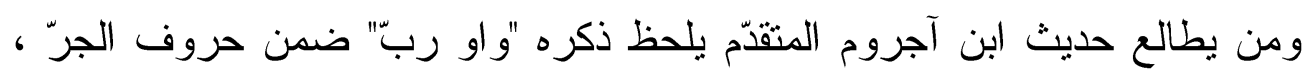

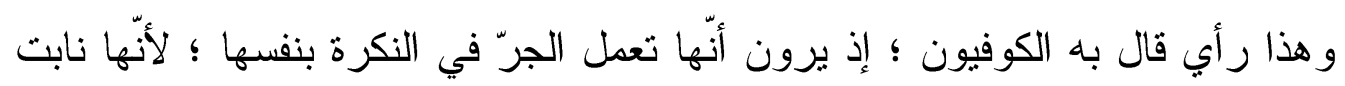

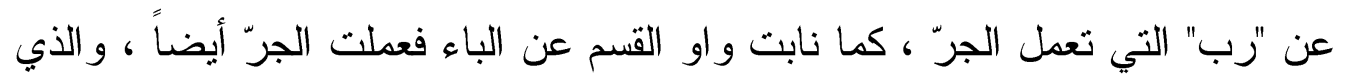

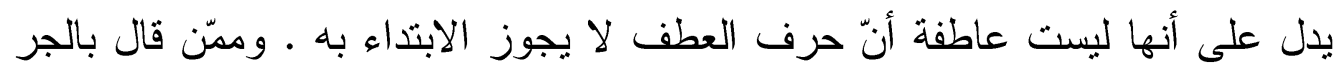

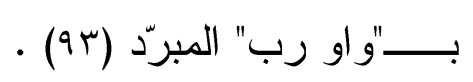

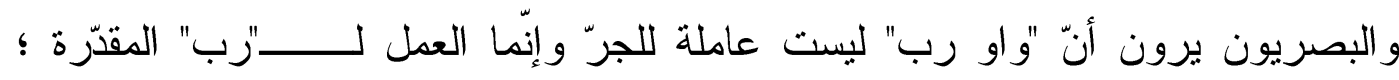

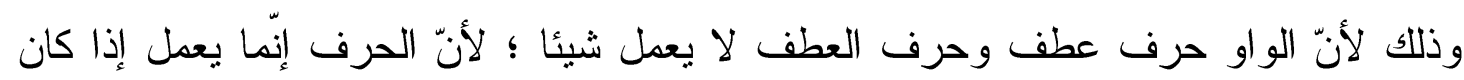
مختصاً ، وحرف العطف غير مختص ؛ فوجب أن لا يكون عاملاً ، و الذي يدل على أنس أنها

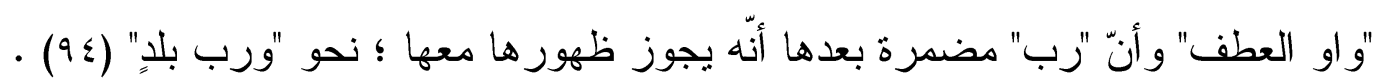

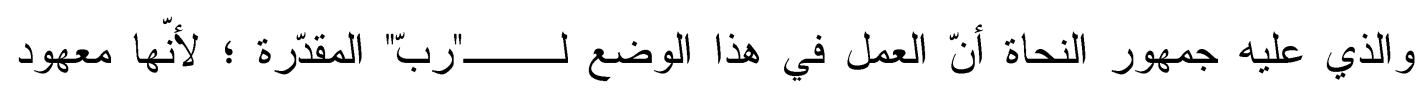

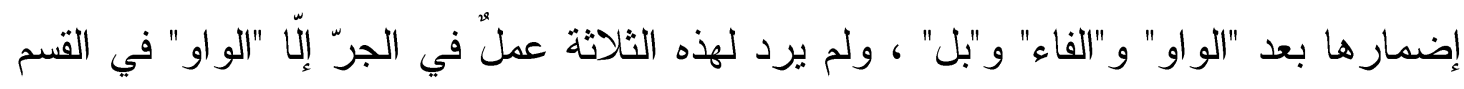

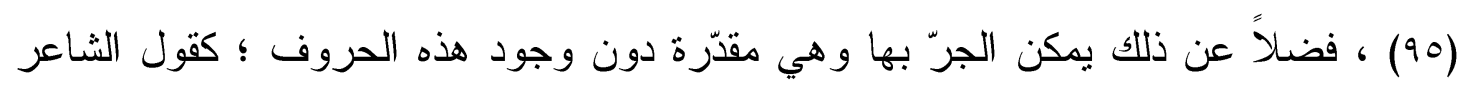

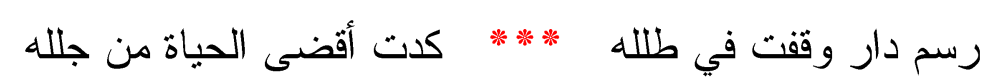

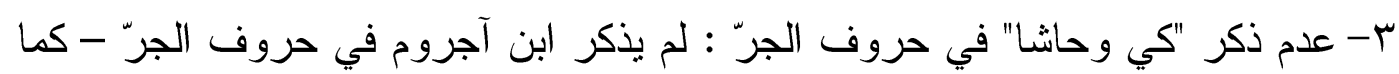

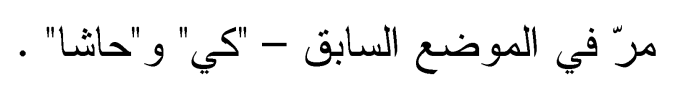

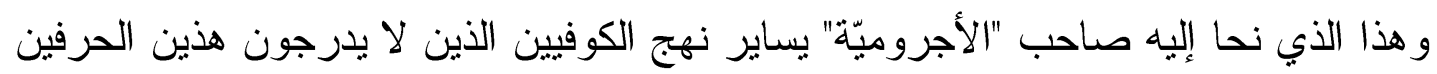

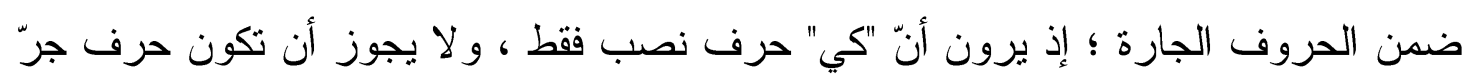

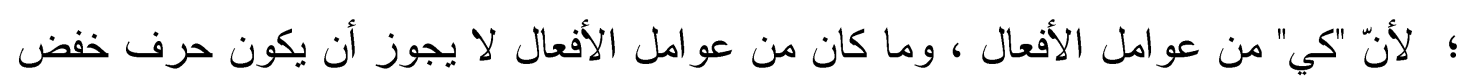

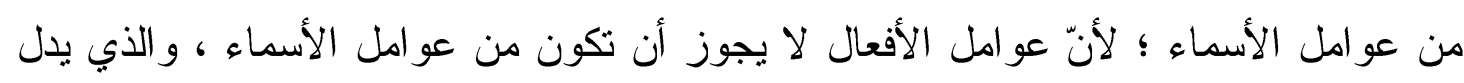

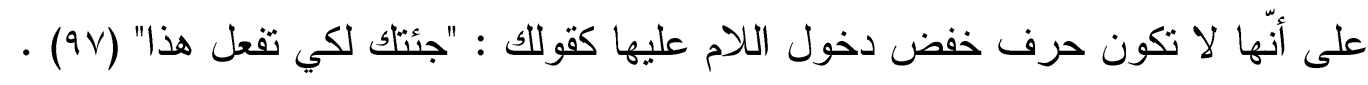

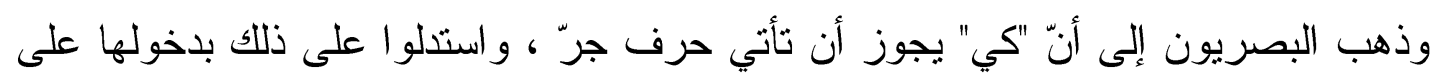

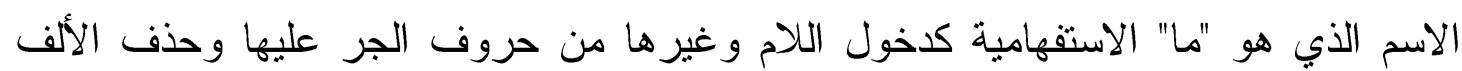

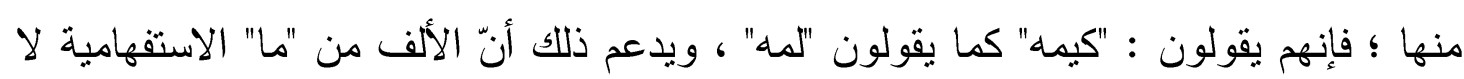


تُحذف إلا إذا كانت في موضع جر و اتصل بها الحرف الجار ؛ كقولهم : لَِّ ، وبِحَ ، وفِيمَ ، عََّّ

ويمكن الاعتر اض على رأي الكوفيين في عمل "كي" السابق بما ذهبوا إليه من نصب "حتى"

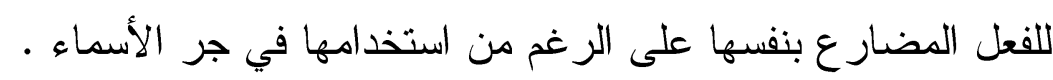

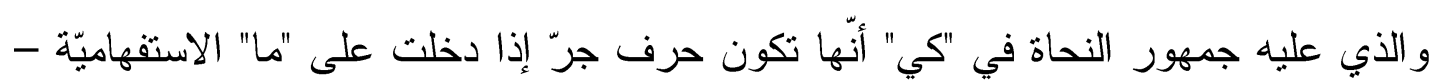

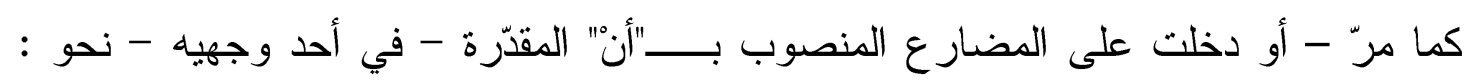

حضرت كي أقابلَ محمداً ، أو دخلت على "ما المصدرية" كقول الثاعر (99) :

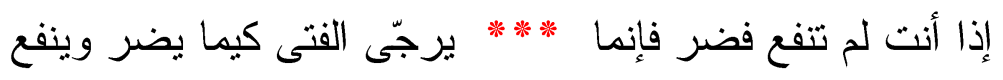

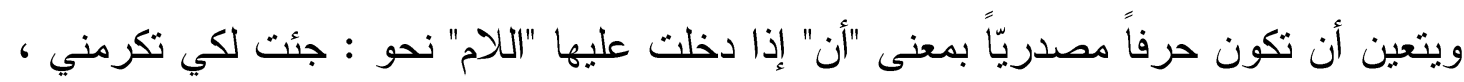

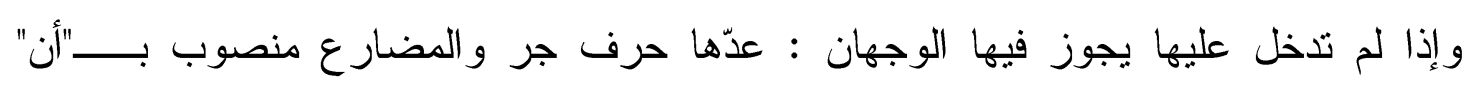

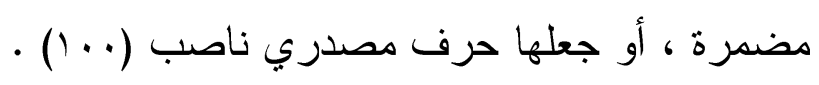

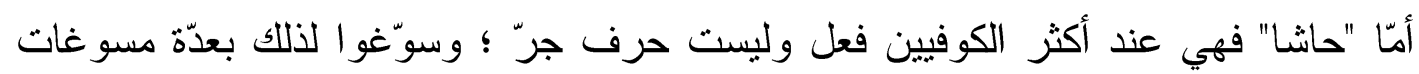

منها أنّها تتصرّت فيقال : حاشيته ، وأحاشيه ، ومنه قول النابغة (1 ـ (1) :

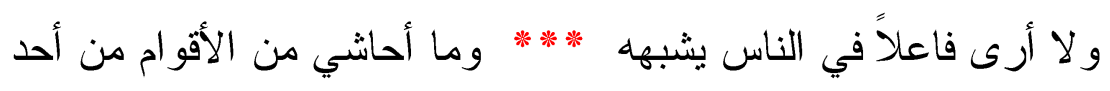

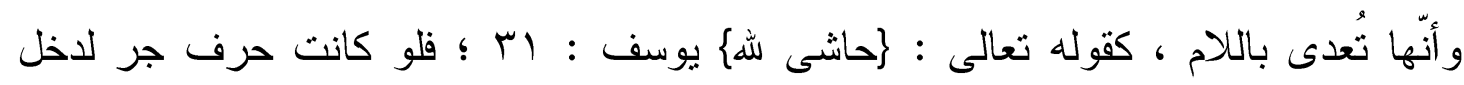

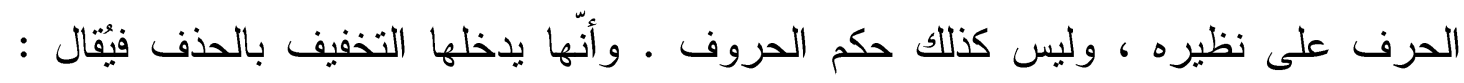

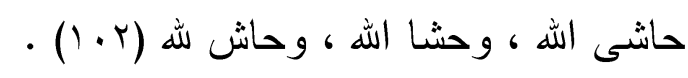

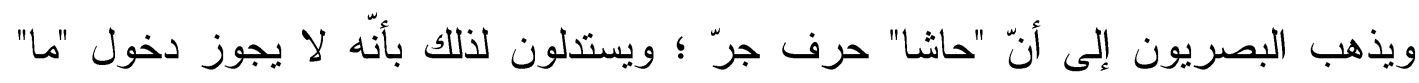

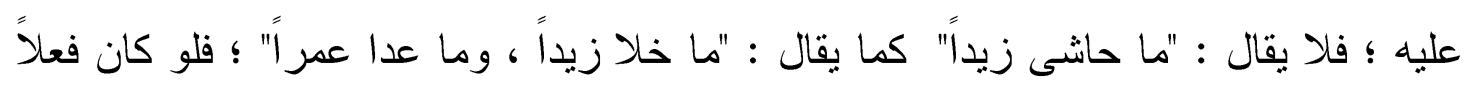

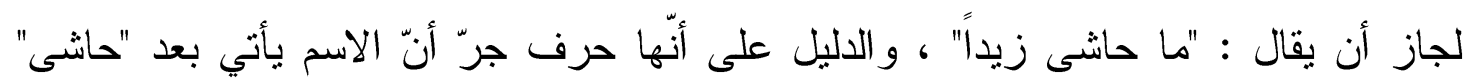

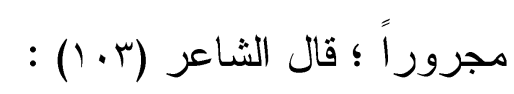

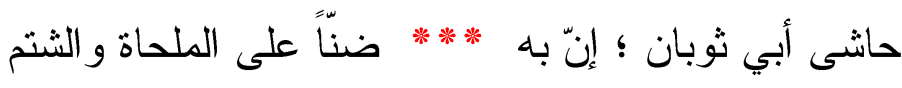

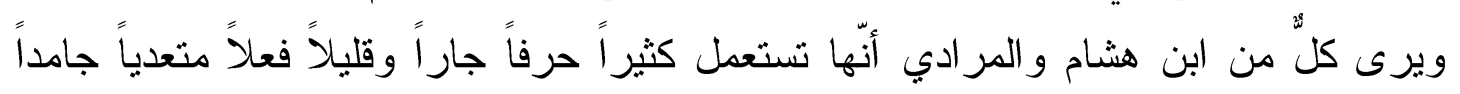

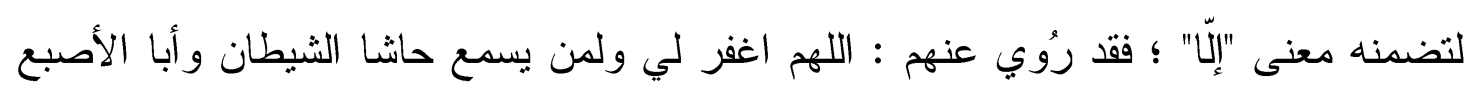
$\cdot(1 \cdot \varepsilon)$

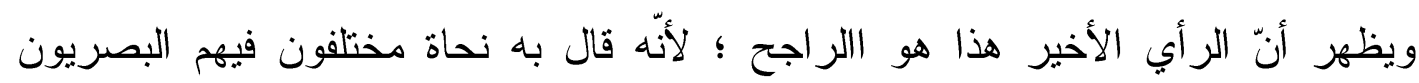

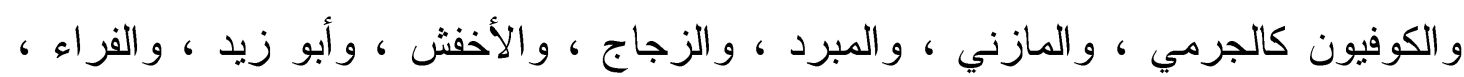

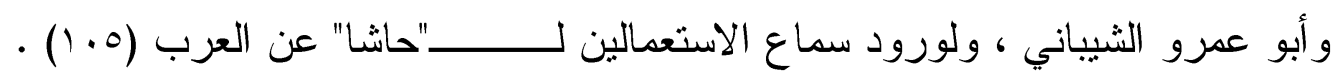




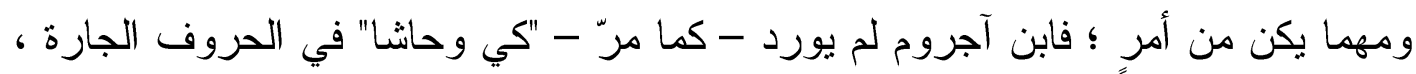

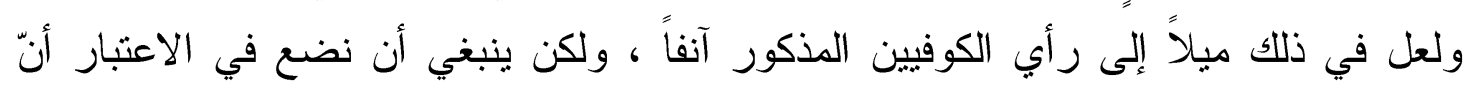

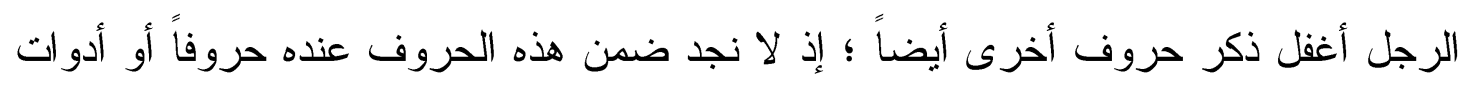

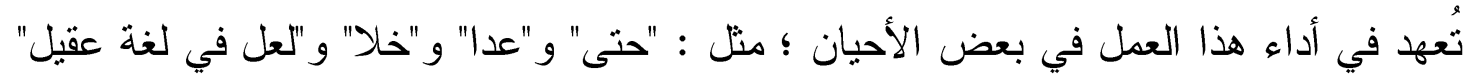

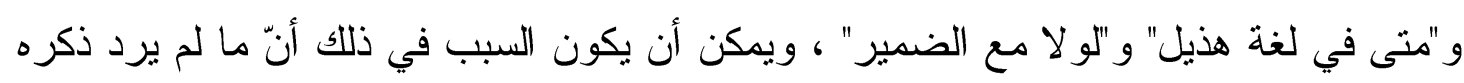

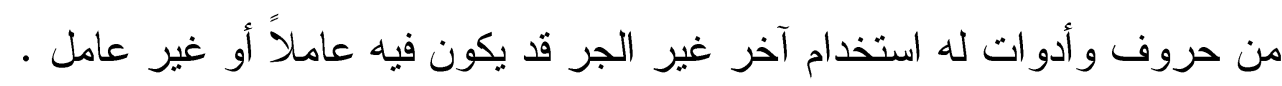

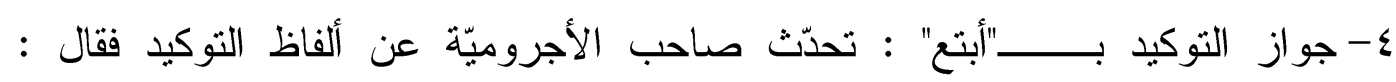

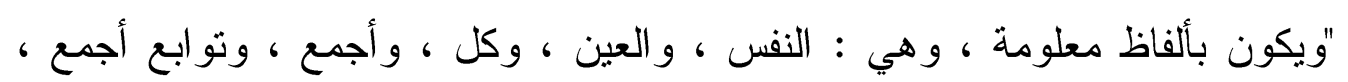

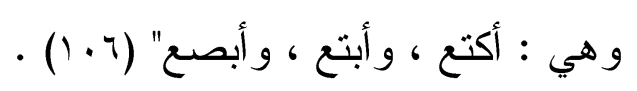

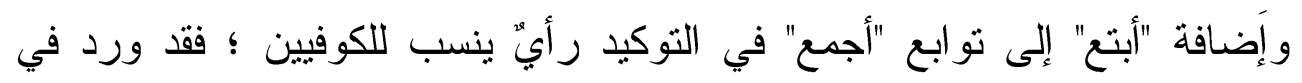

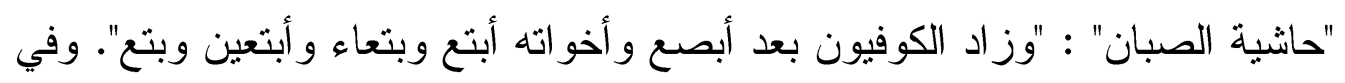

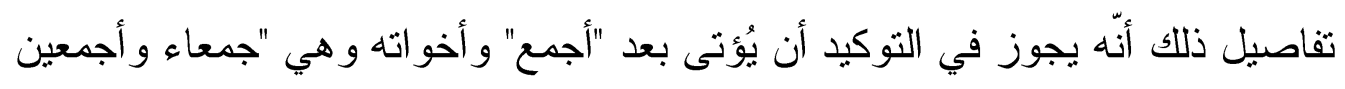

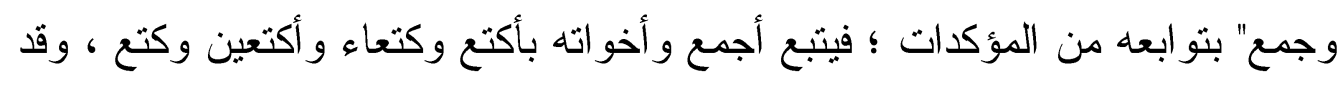

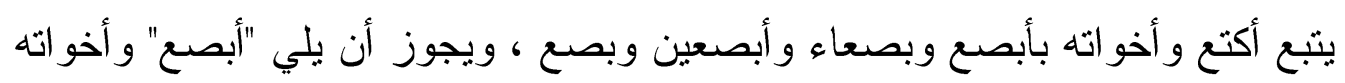

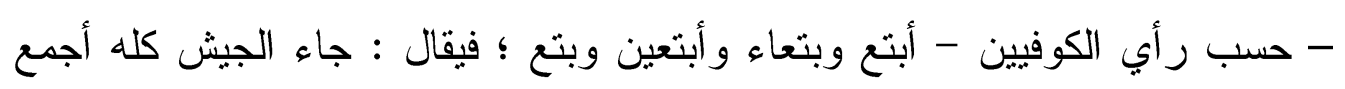

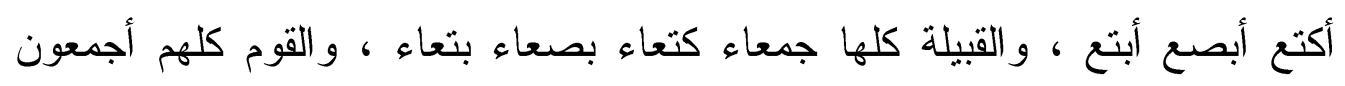

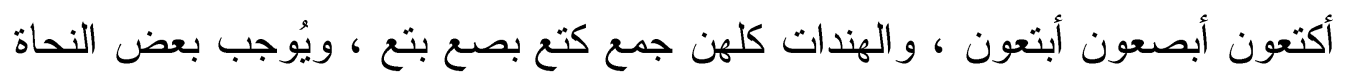

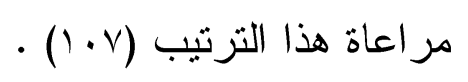

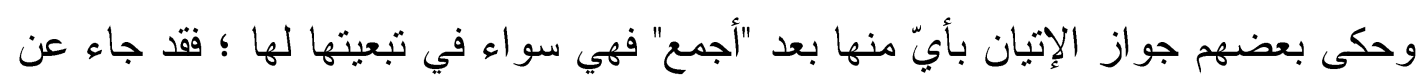

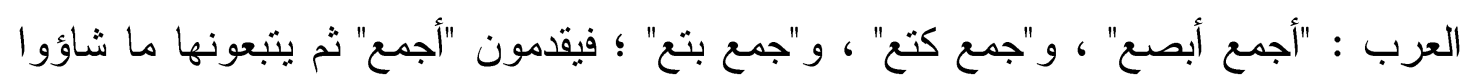

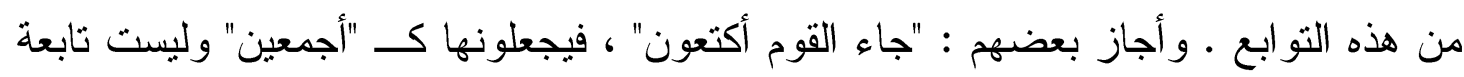

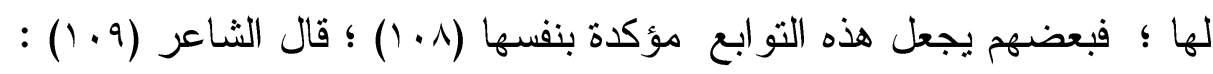

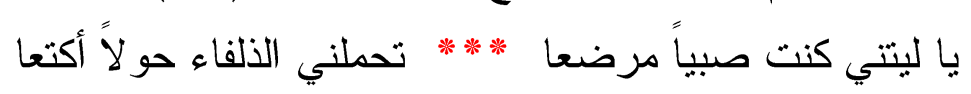

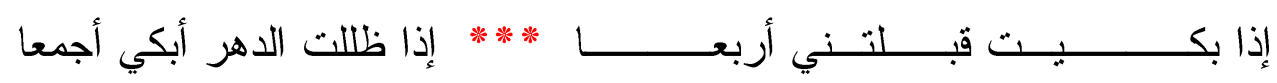

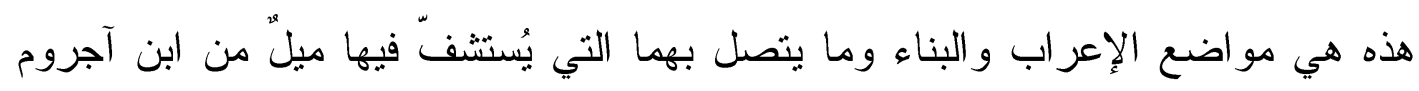

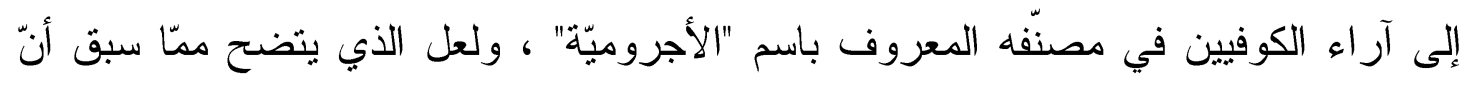

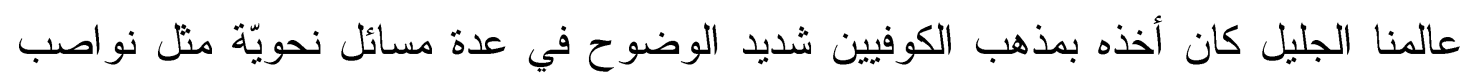

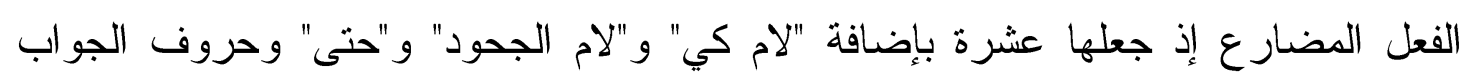


وهي "الو او و الفاء وأو" على ما هو متّفق عليه وهي : "أن" و"لن" و "إذن" و "كي" ، و إيراده

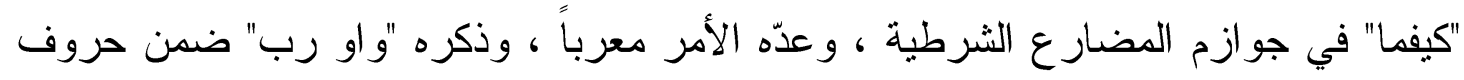

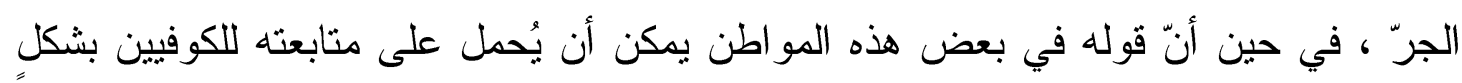

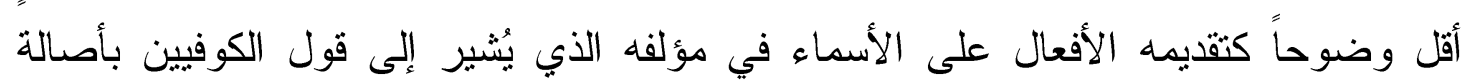
الفعل ، و عدم ذكره "كي" في حروف الجرّ.

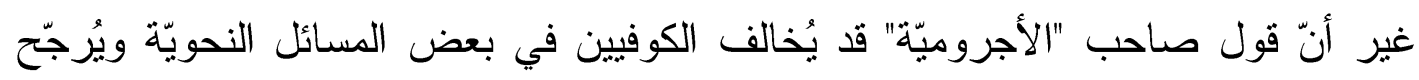

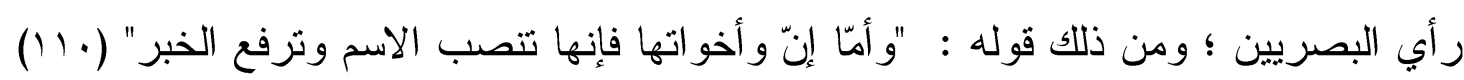

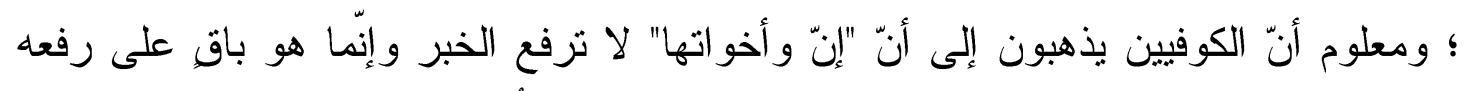

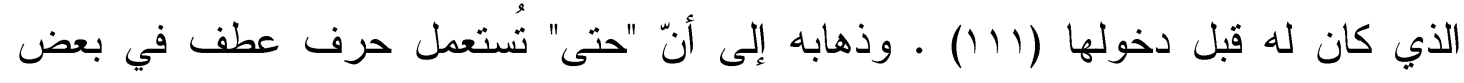

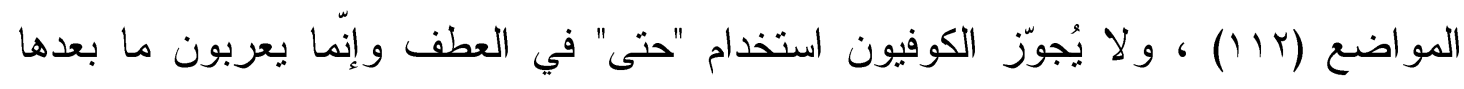

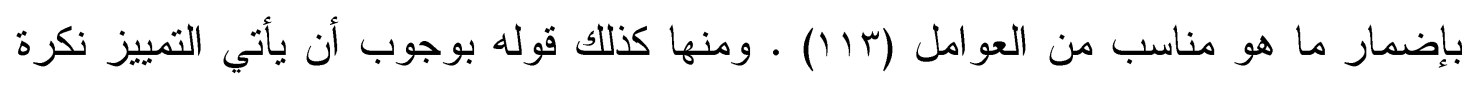

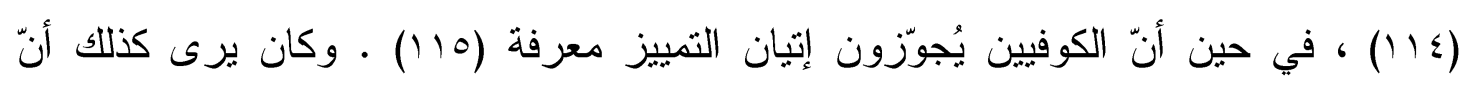

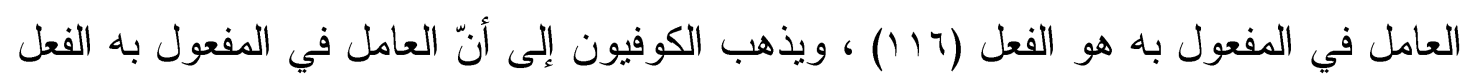

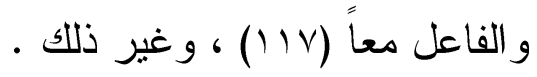

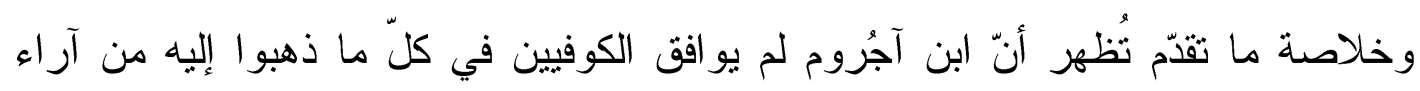

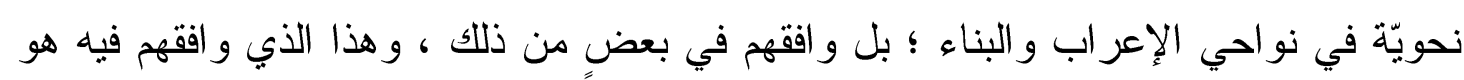

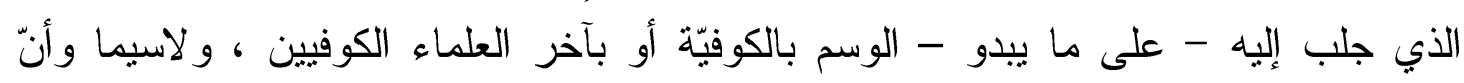

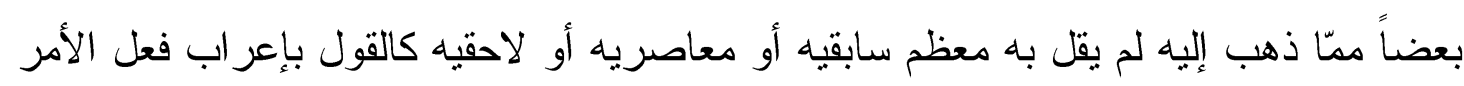

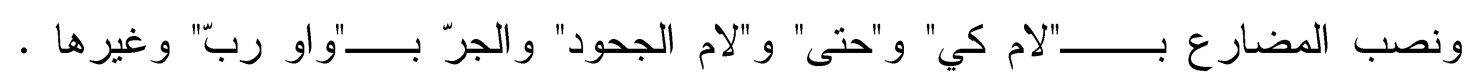

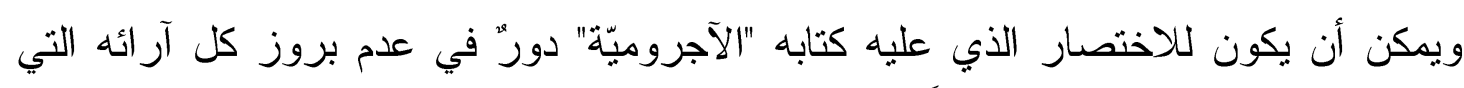

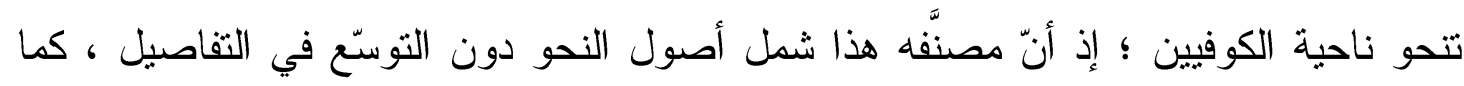

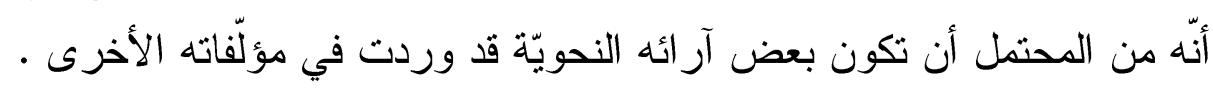

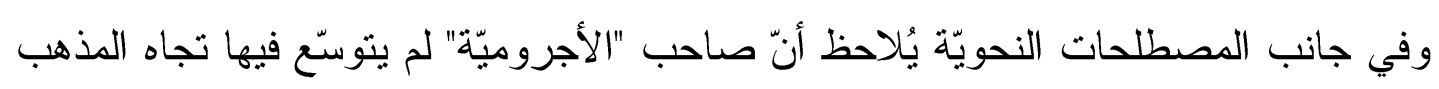

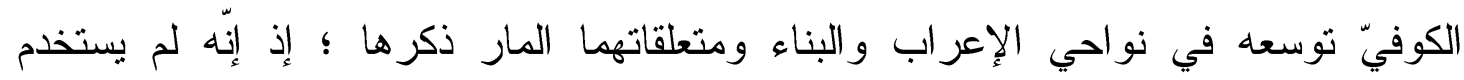

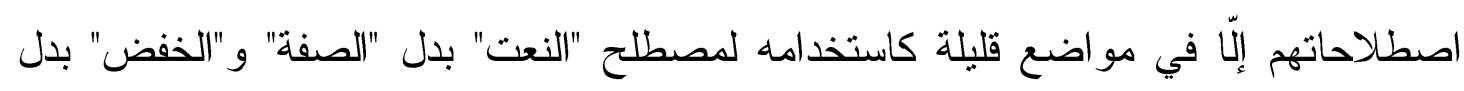

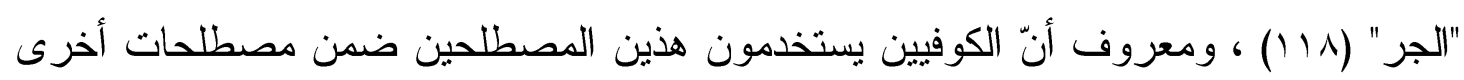

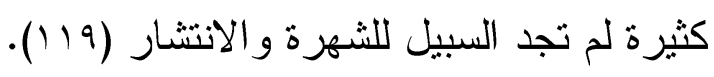


وظلّت المصطلحات النحويّة السائدة عند ابن آجروم في مؤلّفه - في الغالب الأعم - هي

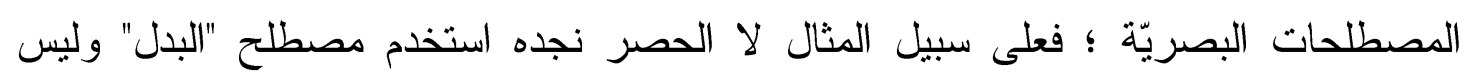

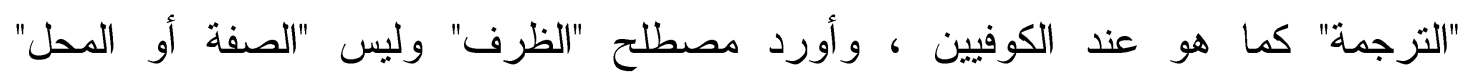

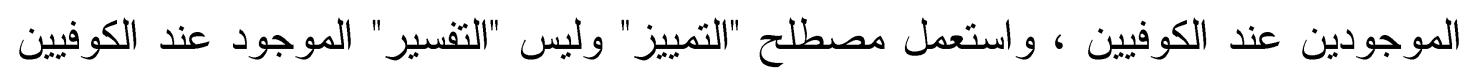

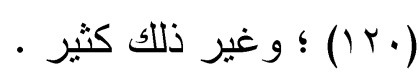
وربّما يكون السبب في غلبة اصطلاحات البصريين على كتابه أنّه آثر أن يستخدم

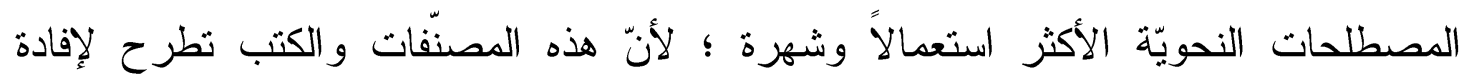
طلاب العلم و المعرفة ؛ فينبغي أن تُلقى بين أبديهم بمصطلحاتها التي عهدو ها و لا يُؤتى إليهم

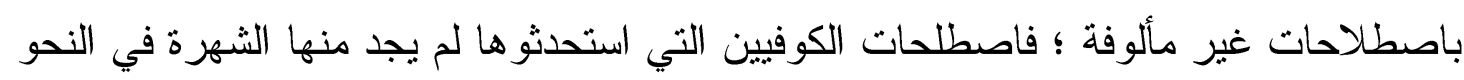
العربي إلا القليل كالنعت وعطف النسق وحروف الإضافة وظلت المصطلة فاصلحات البصريّة هي

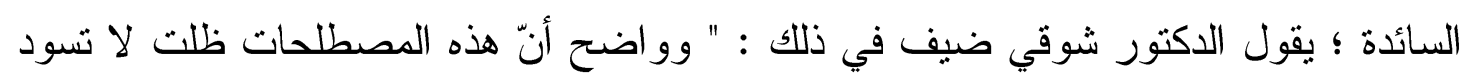

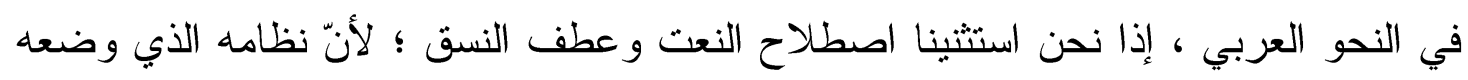

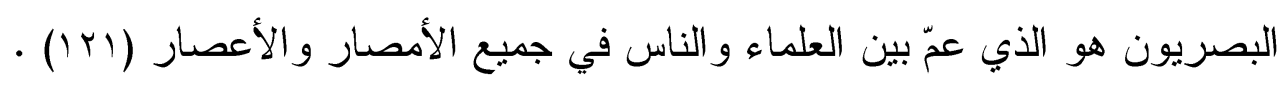

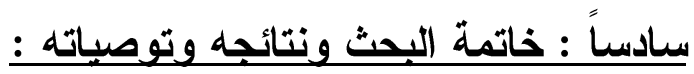

حاولت هذه الدراسة النظر في ميل ابن آجرُوم إلى آراء الكوفيين من خلادل مُؤلَفه

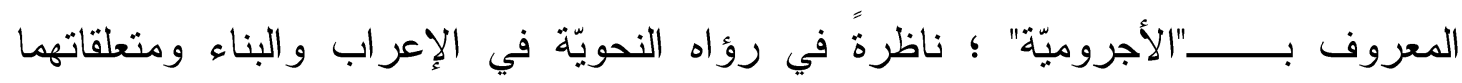

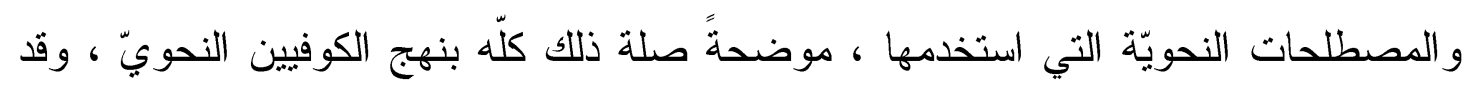

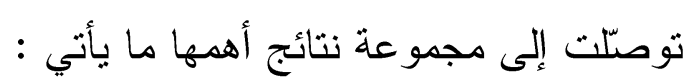

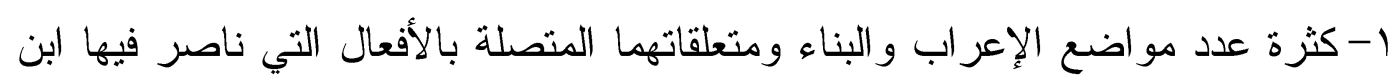

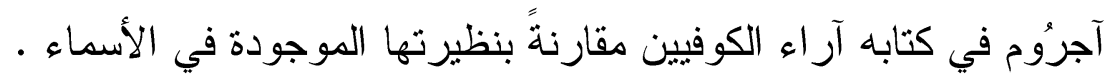

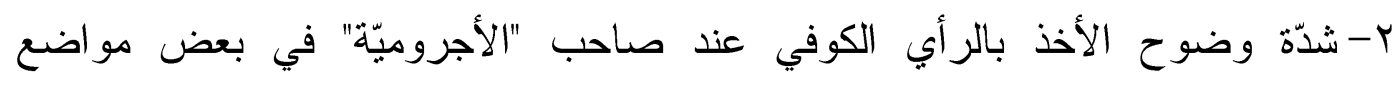

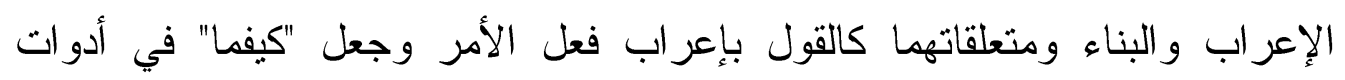

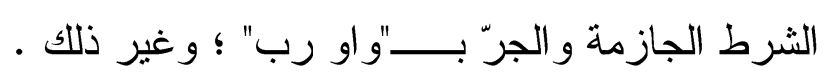

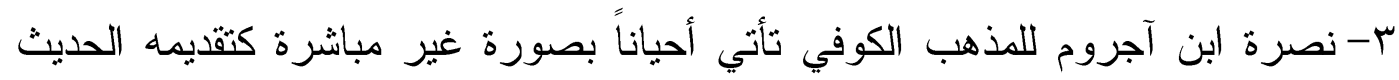

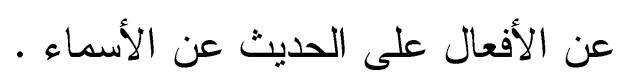
ع-ترجيح احتمال أن يكون الاختصار الذي عليه "متن الأجروميّة" هو الذي أسهم في عدم الأهماه

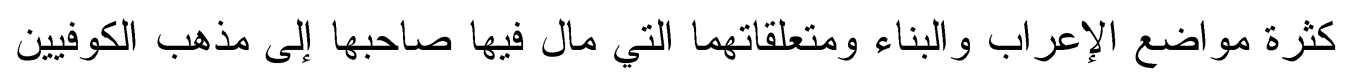

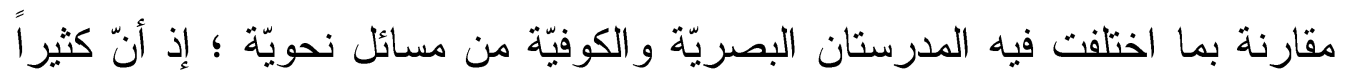


من الاختلافات بين المذهبين كان في العوامل وما يتّصل بها وهذا ما لم يجنح إليه

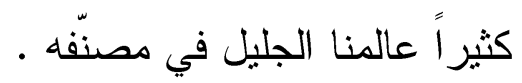
ه- ظهور أخذه برأي البصريين في بعض نواحي الإعراب و البناء وما يتعلّق بها ؛ كما

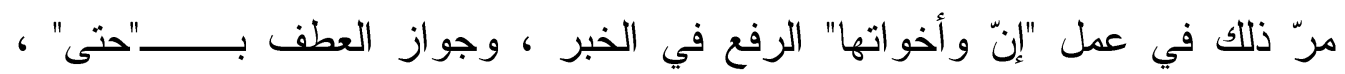

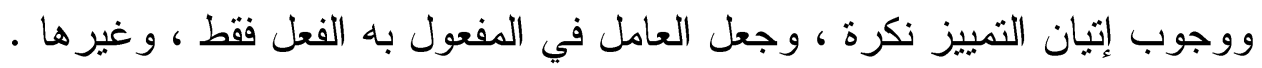

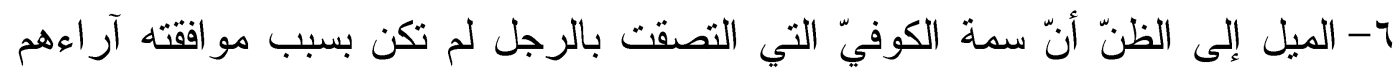

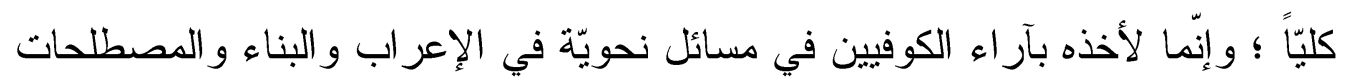

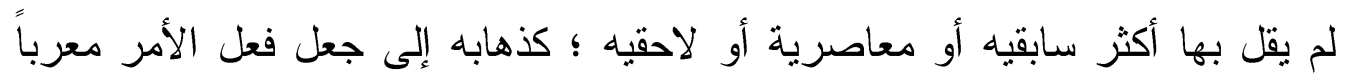

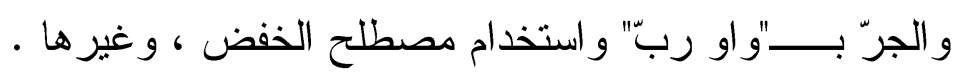

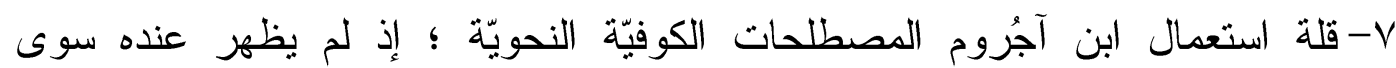

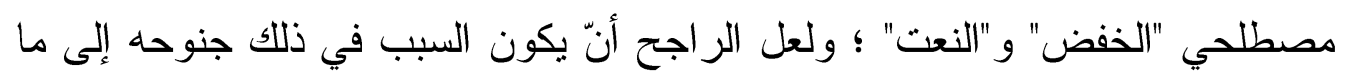

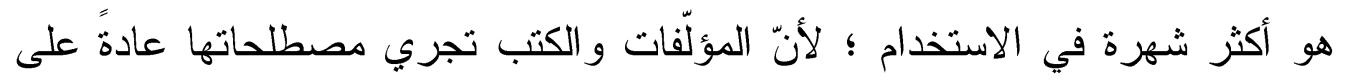

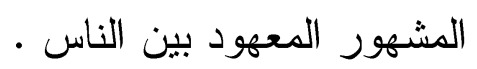

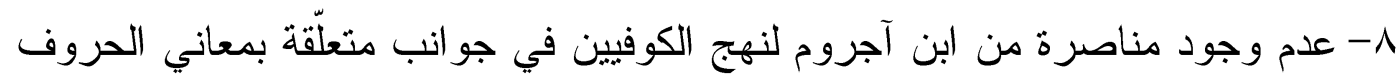

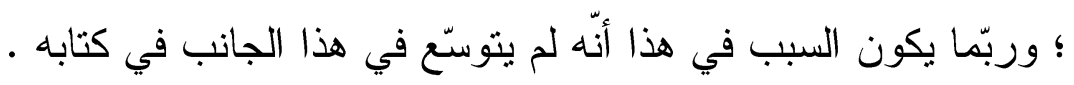

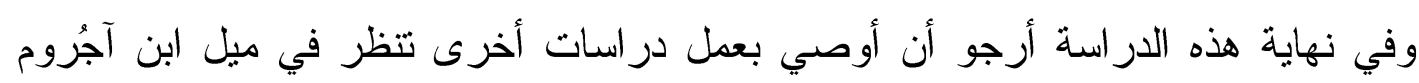

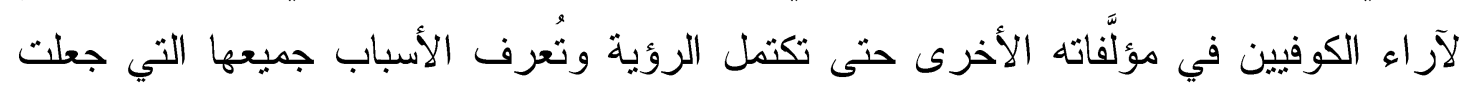

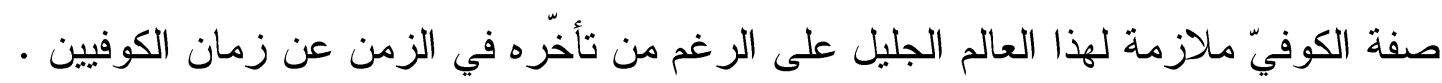

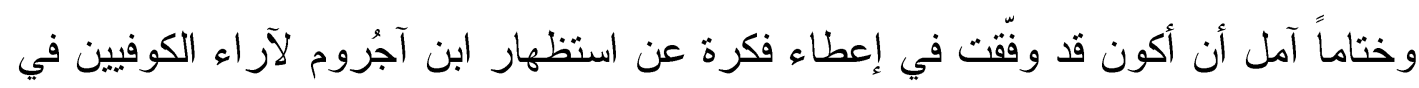

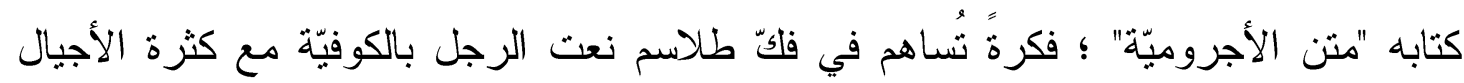
التي تفصله عن علماء المدرسة الكوفيّة . لمنية 


\section{سبابعاً : هو امش البحث : البش:}

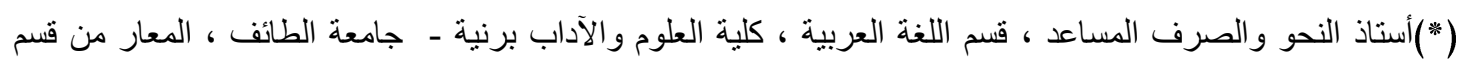
اللغة العربية - كلية التربية - جامعة الخرطوم . mohammedahamedrr@yahoo.com

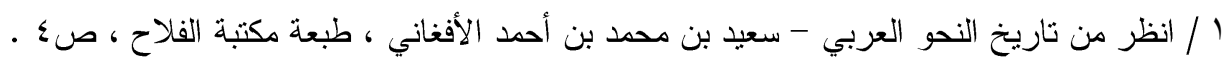

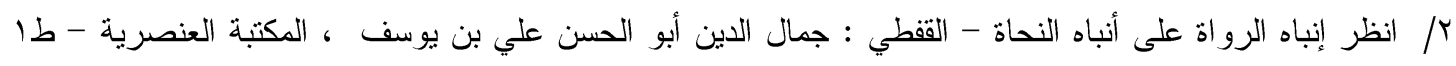

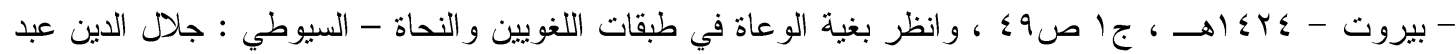

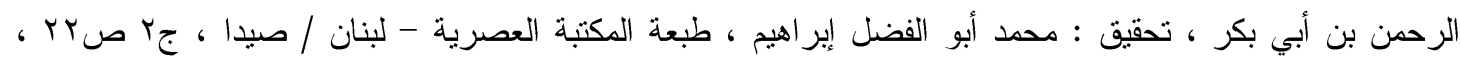

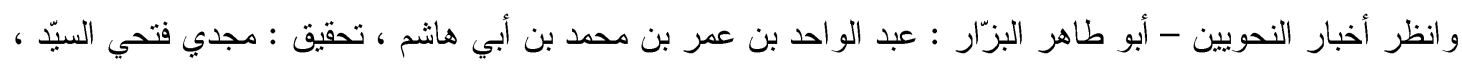

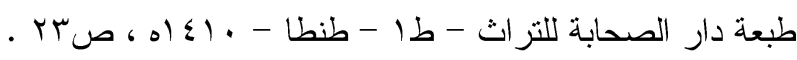

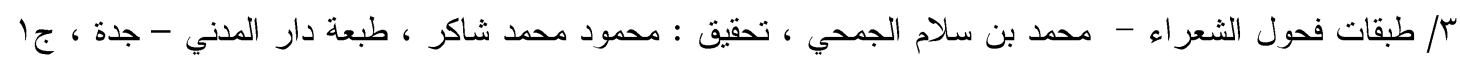

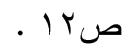
ـ/ الأغاني - أبو الفرج الأصفهاني : علي بن الحسين ، تحقيق : د. إحسان عباس ود. إبراهيم السعافين والأستاذ :

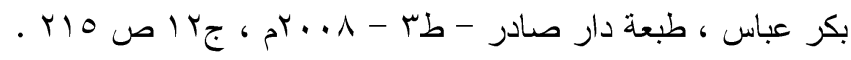

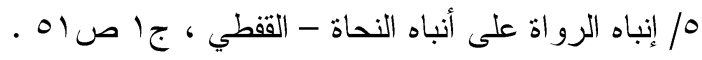

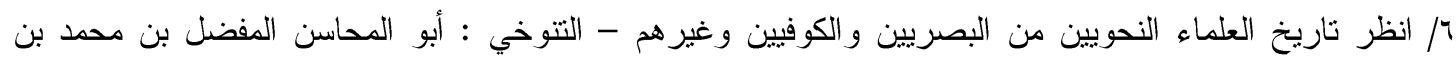

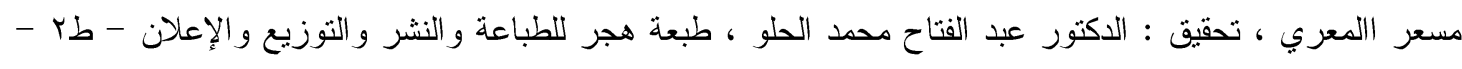

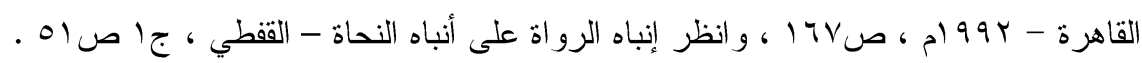

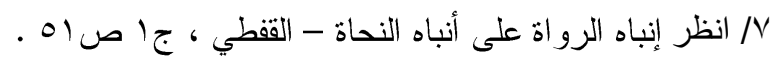

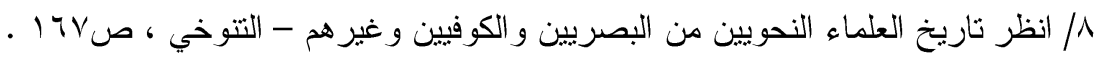

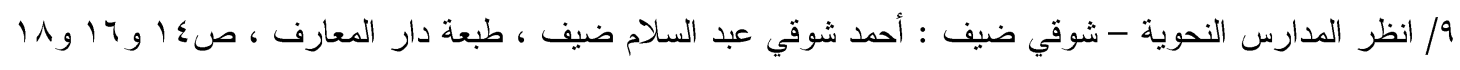

.// رليية : عربيّ أصيل : خالص النسب ، لحب الطريق : بيّنة .

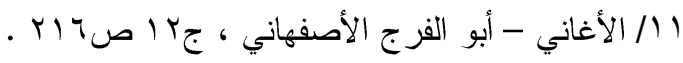

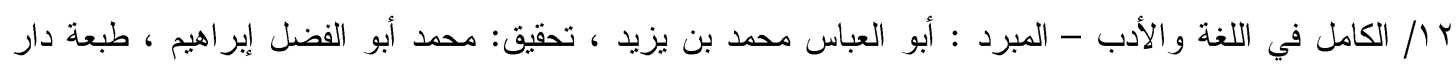

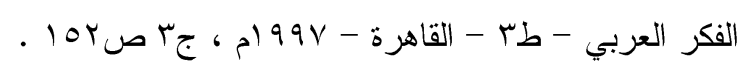

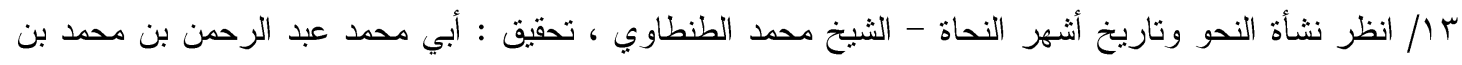

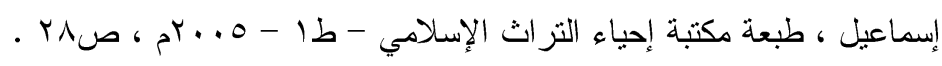

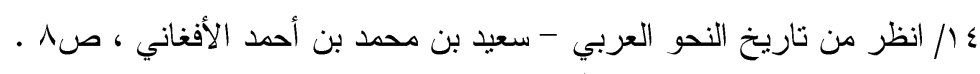

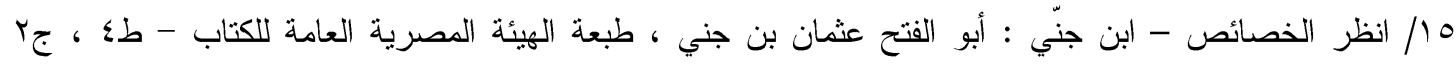
ص. الح/ / انظر نزهة الألباء في طبقات الأدباء - ابن الأنباري : أبو البركات كمال الدين عبد الرحمن بن محمد بن عبيد الله

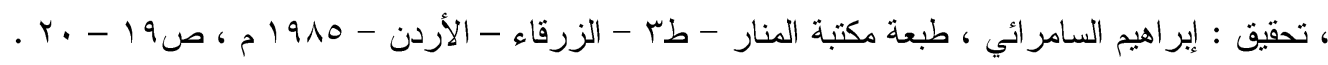

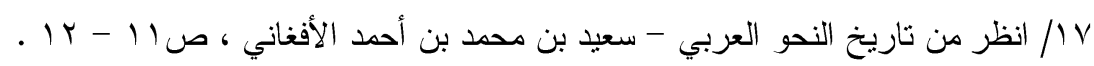

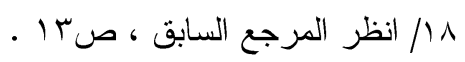


9 / / انظر الأضداد - ابن الأنباري : محمد بن القاسم ، تحقيق : محمد أبو الفضل إبراهيم ، طبعة المكتبة العصرية -

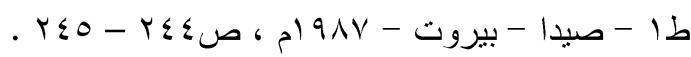

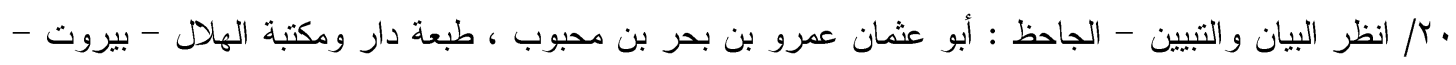

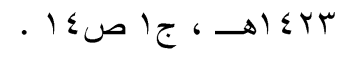

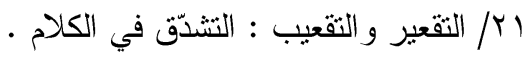

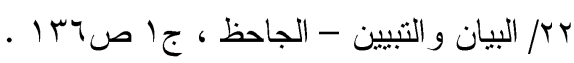

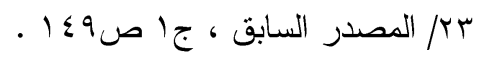

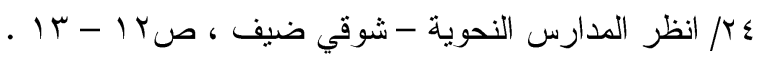

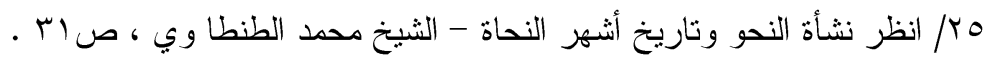

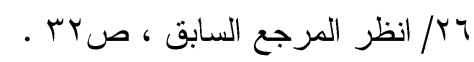

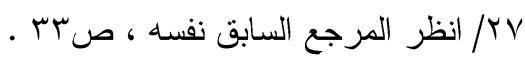

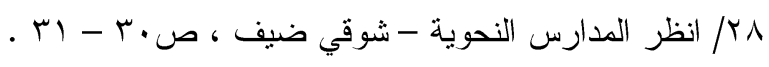

9 و/ انظر أخبار النحويين البصريين ، السيرافي : أبو سعيد الحسن بن عبد الله بن المرزبان ، تحقيق : طه محمد

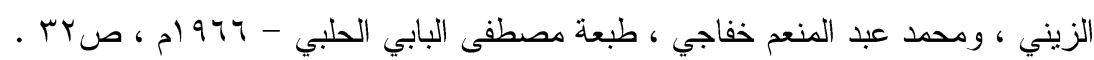

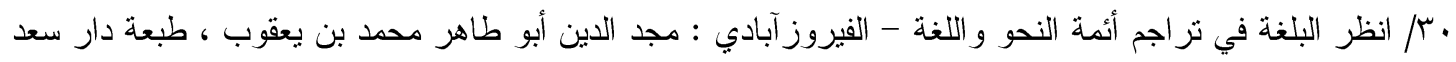

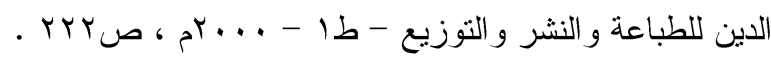

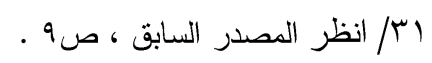

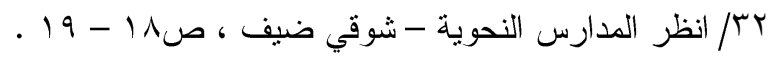

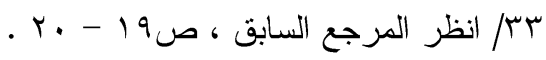

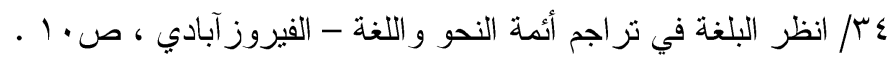

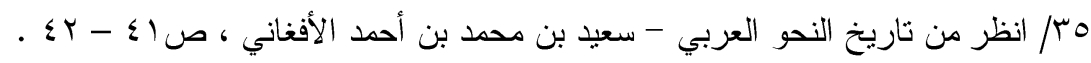

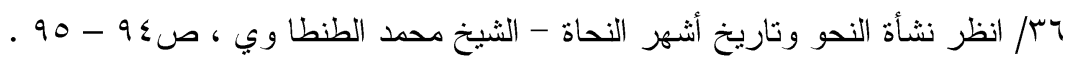

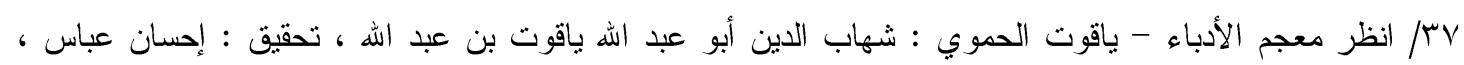

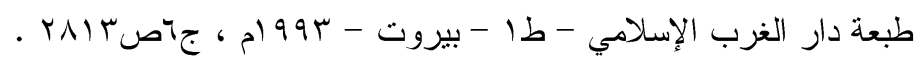

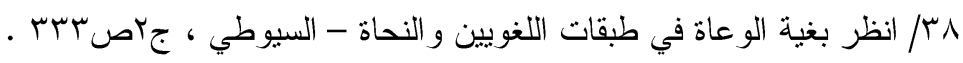

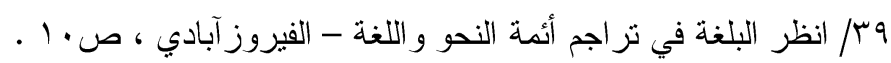

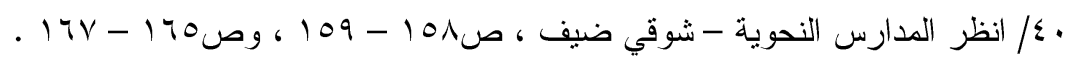

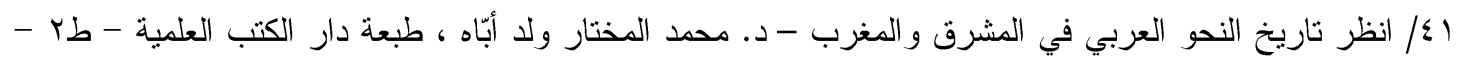

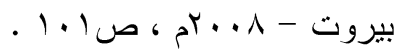

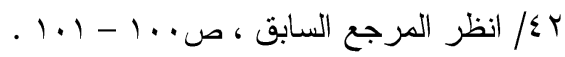

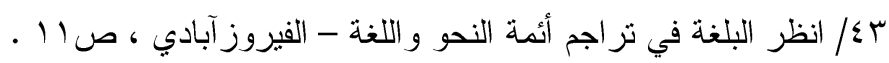

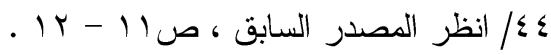

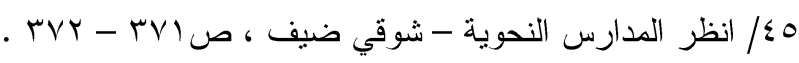

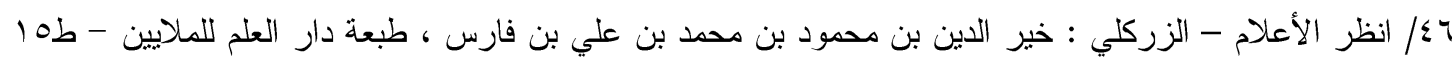




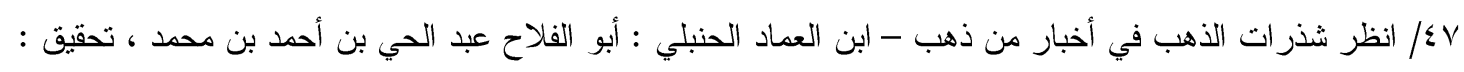

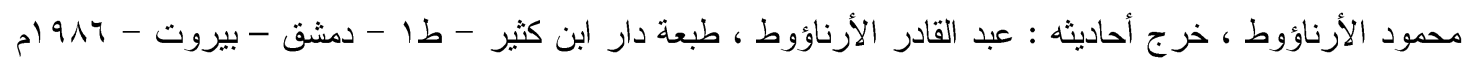

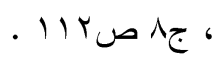

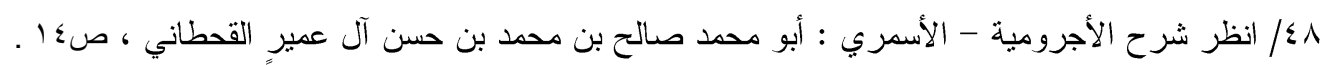

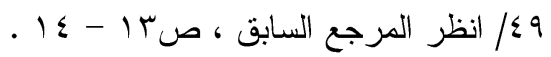

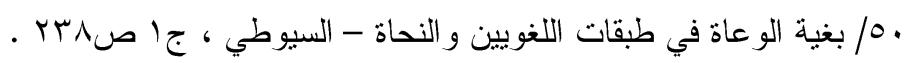

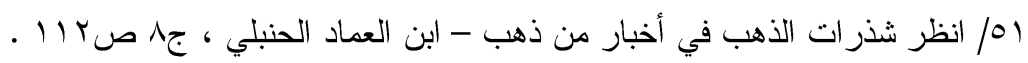

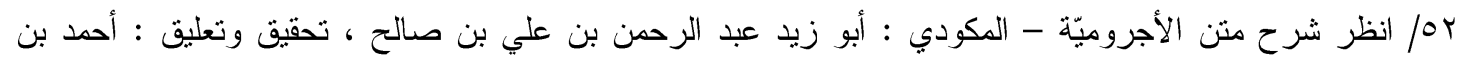

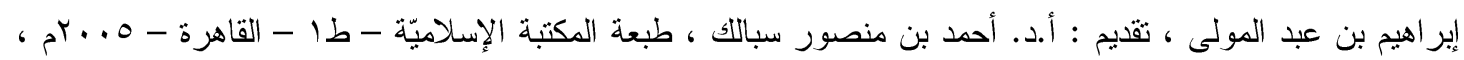

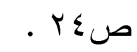

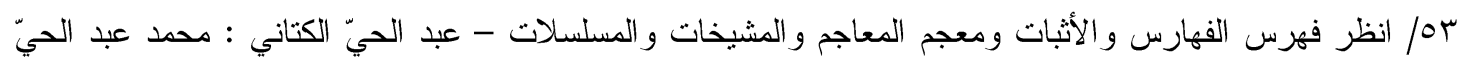

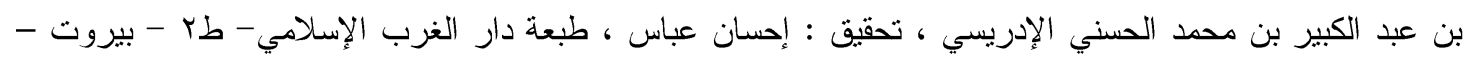

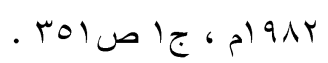
ـ/ انظر التوضيحات الجليّة في الأجروميّة - محمد الهاشمي ، اعتنى به : حايف النبهان ، طبعة دار الظاهريّة للنشر

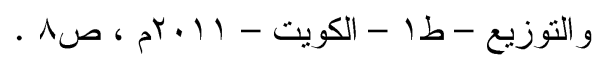

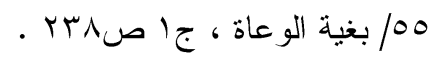

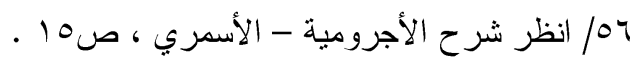

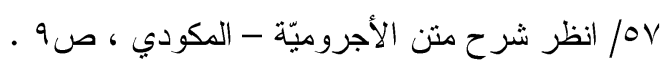

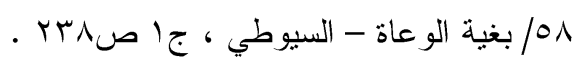

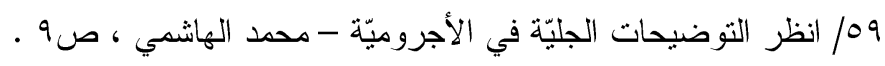

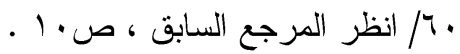

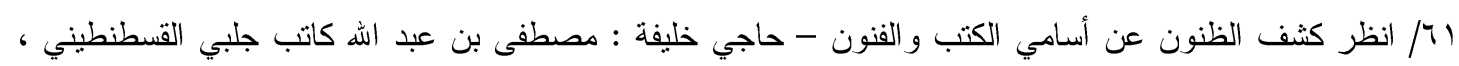

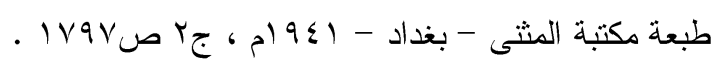

ب ب/ انظر هدية العارفين أسماء المؤلفين وآثار المصنفين - إسماعيل بن محمد أمين بن مير سليم ، طبع بعناية وكالة

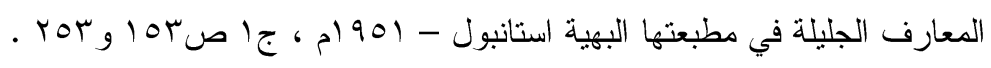

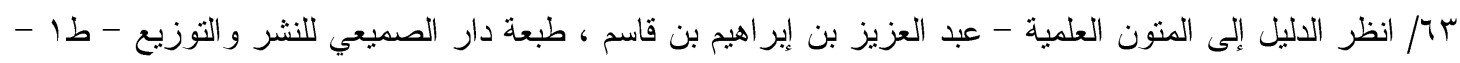

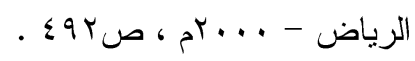

ـ آ/ انظر إيضاح المكنون في الذيل على كثف الظنون - إسماعيل بن محمد أمين بن مير سليم ، عنى بتصحيحه

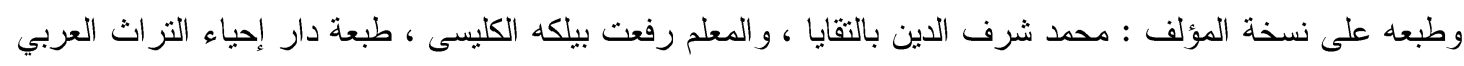

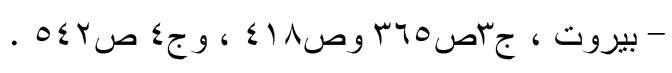

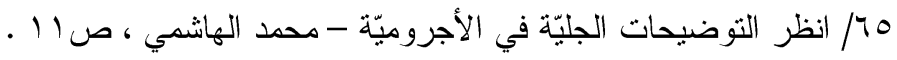

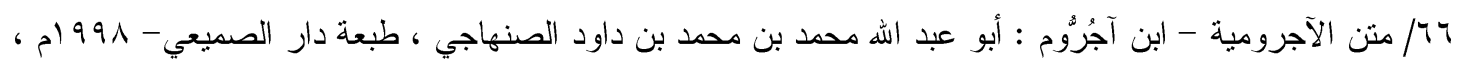
ص1/1 Vآ/ انظر الإنصاف في مسائل الخلاف بين النحويين : البصريين والكوفيين - ابن الأنباري : أبو البركات كمال الدين

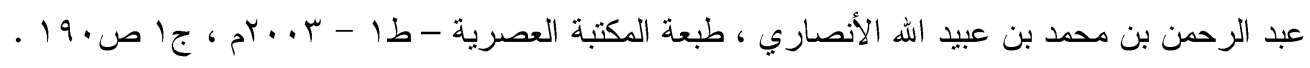




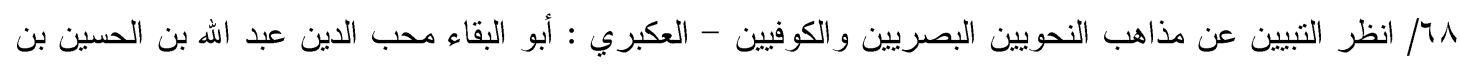

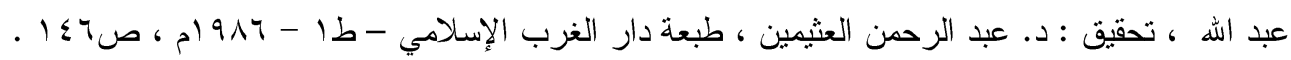

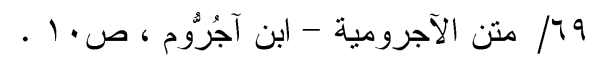

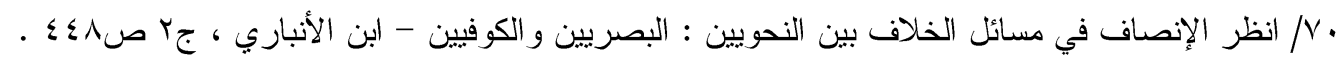

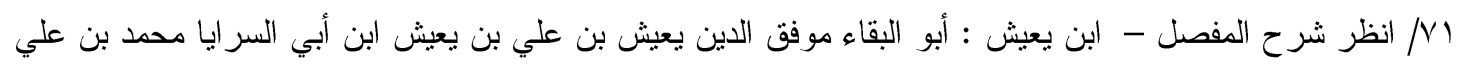

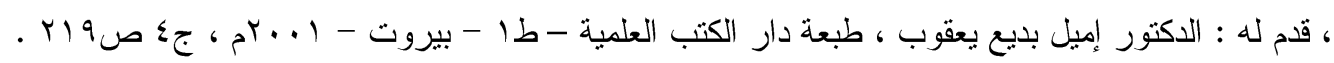

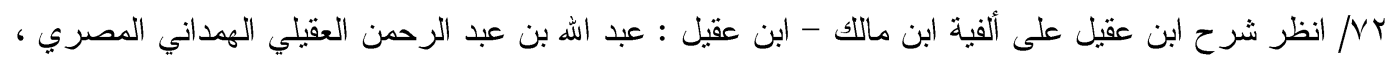

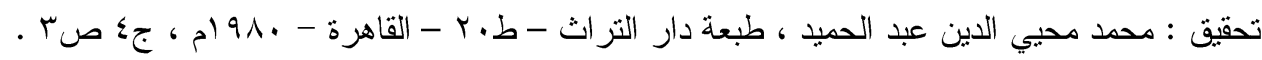

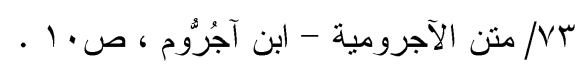

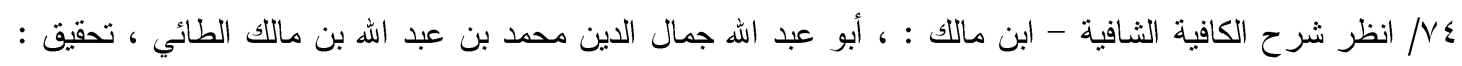

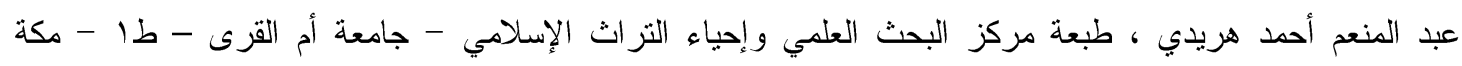

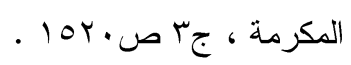

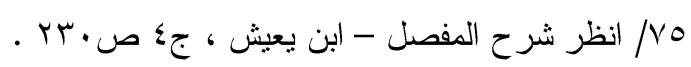

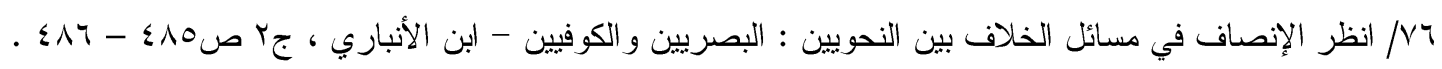

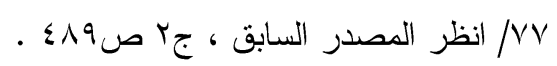
N / انظر مغني اللبيب عن كتب الأعاريب - ابن هشام : أبو محمد جمال الدين عبد الله بن يوسف بن أحمد بن عبد الله

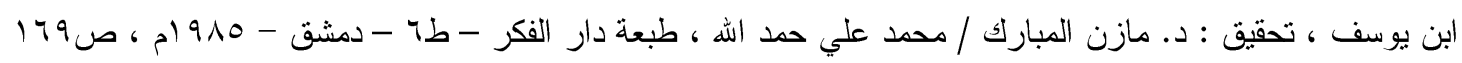

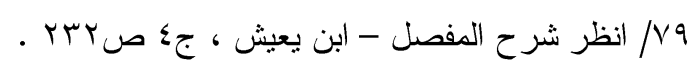

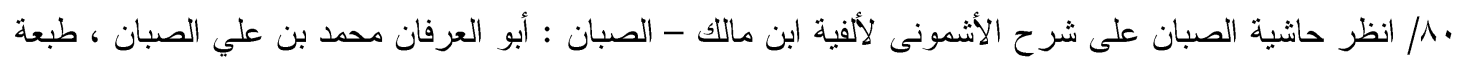

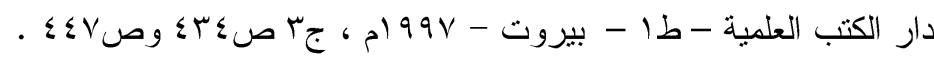

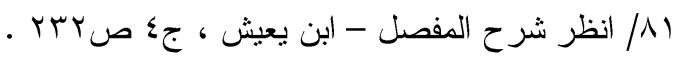

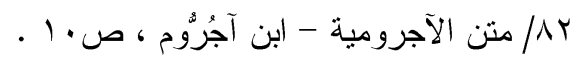

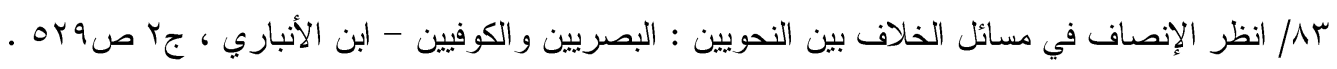

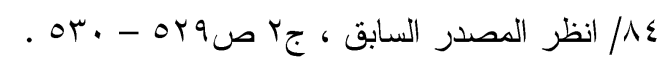

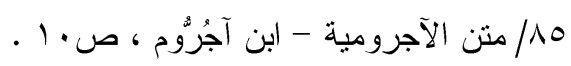

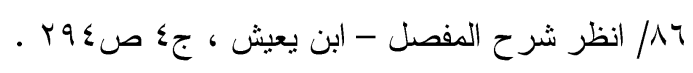

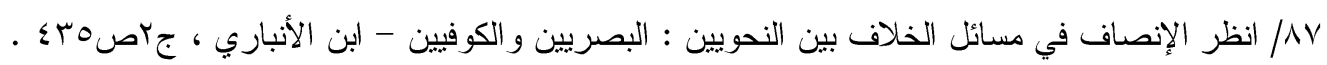

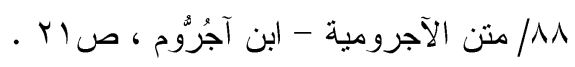

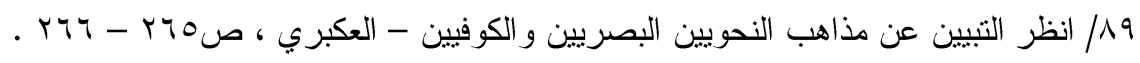

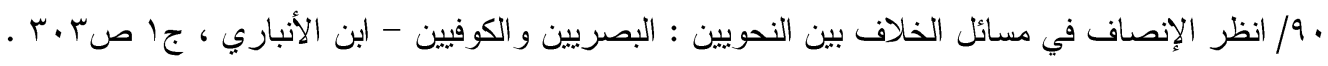

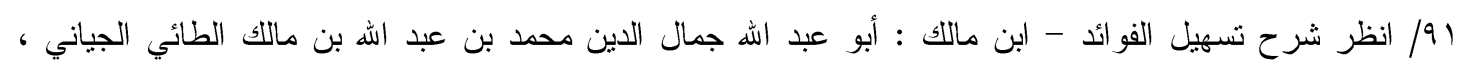

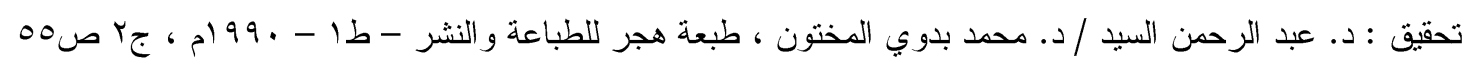

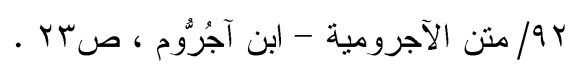

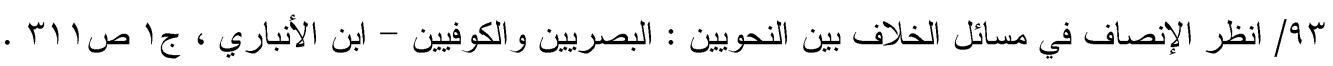




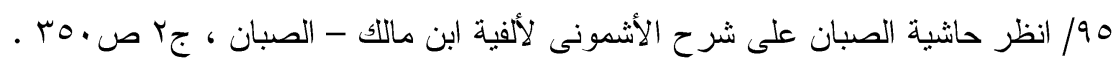

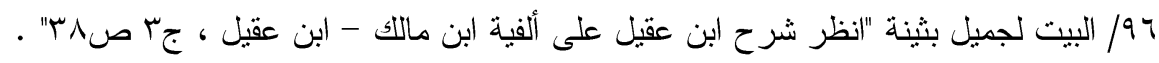

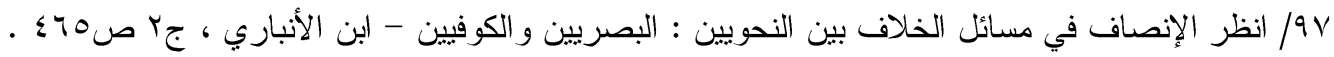

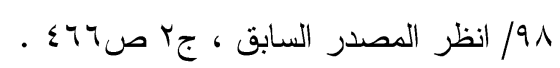

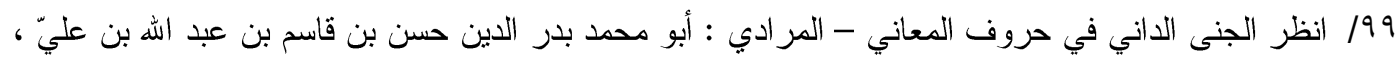

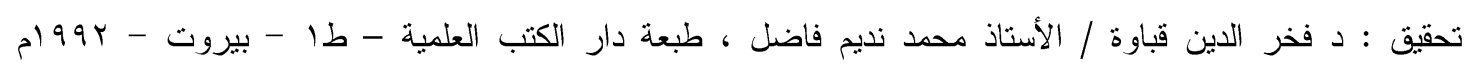
שתזיזים

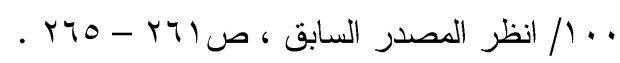

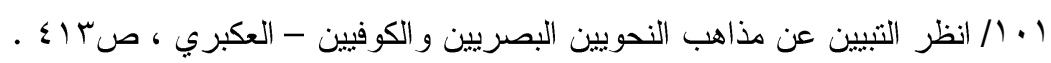

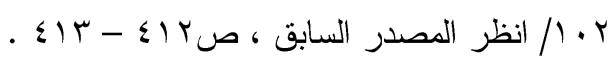

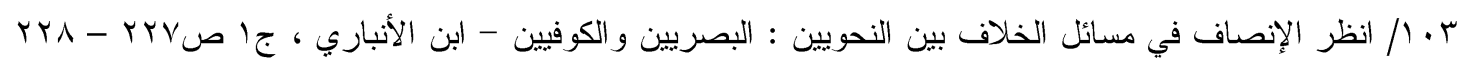
ـ ـ 1/ انظر مغني اللبيب عن كتب الأعاريب - ابن هشام ، ص171 ـ ـ وانظر الجني الداني في حروف المعاني -

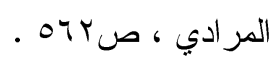

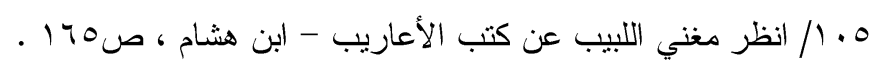

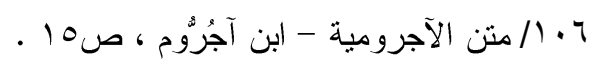

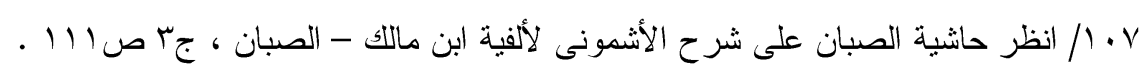

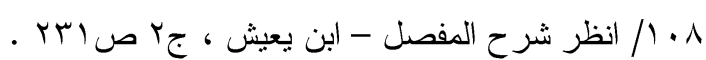

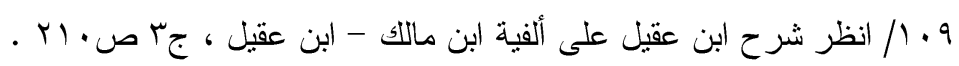

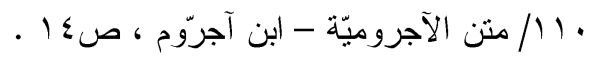

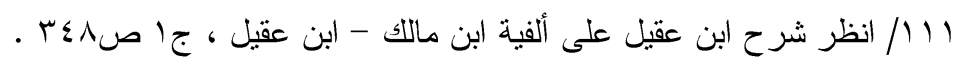

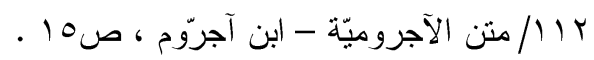

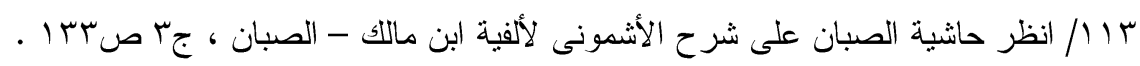

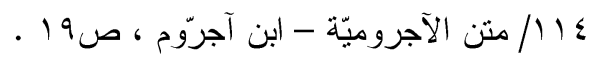

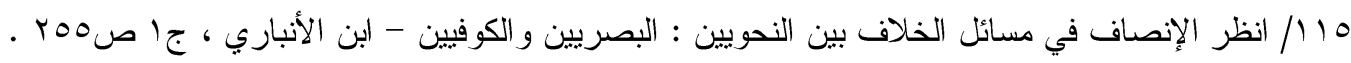

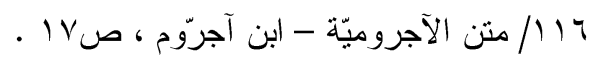

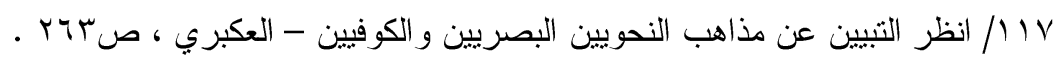

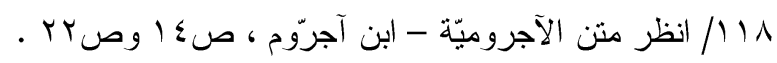

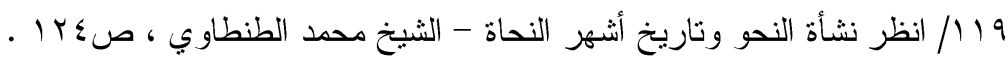

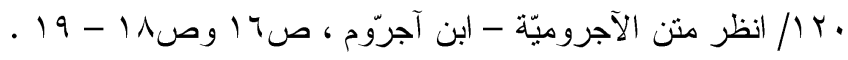

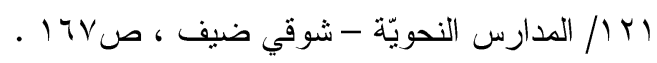


ثامناً : المصادر و المراجع :

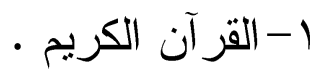

r-أخبار النحويين - أبو طاهر البزّار : عبد الواحد بن عمر بن محمد بن أبي

هاثم ، تحقيق : مجدي فتحي السبّّ ، طبعة دار الصحابة للتراث - طا -

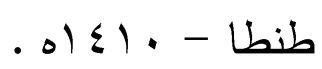

r-أخبار النحويين البصريين ، السيرافي : أبو سعيد الحسن بن عبد الله بن المرزبان ، تحقيق : طه محمد الزيني ، ومحمد عبد المنعم خفاجي ، طبعة

$$
\text { مصطفى البابي الحلبي - } 1977 \text { ام . }
$$

ع- الأضداد - ابن الأنباري : محمد بن القاسم ، تحقيق : محمد أبو الفضل إبراهيم

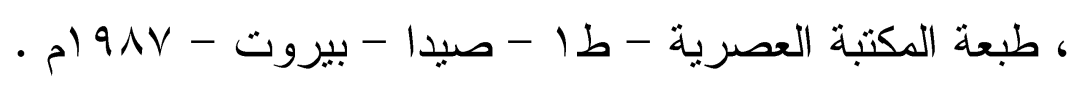

ه- الأعلام - الزركلي : خير الدين بن محمود بن محمد بن علي بن فارس ، طبعة

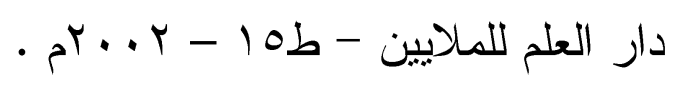

צ-الأغاني - أبو الفرج الأصفهاني : علي بن الحسين ، تحقيق : د. إحسان عباس

ود. إير اهيم السعافين والأستاذ : بكر عباس ، طبعة دار صادر - طب -

$$
\cdot \operatorname{ran}
$$

V- إنباه الرواة على أنباه النحاة - القططي : جمال الدين أبو الحسن علي بن يوسف

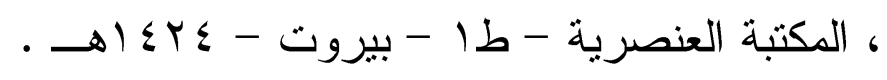

1-الإنصاف في مسائل الخلاف بين النحويين : البصريين والكوفيين - ابن الأنباري : أبو البركات كمال الدين عبد الرحمن بن محمد بن عبيد الله

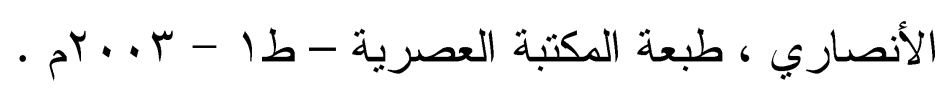

9- إيضاح المكنون في الذيل على كثف الظنون - إسماعيل بن محمد أمين بن مير سليم ، عنى بتصحيحه وطبعه على نسخة المؤلف : محمد شرف الدين بالثقايا ، و المعلم رفعت بيلكه الكليسى ، طبعة دار إحباء النزاث العربي - بيروت . 
• 1-بغية الوعاة في طبقات اللغويين والنحاة - السيوطي : جلال الدين عبد الرحمن بن أبي بكر ، تحقيق : محمد أبو الفضل إبراهيم ، طبعة المكتبة

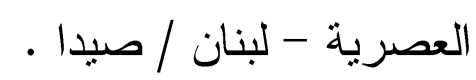

11 - البلغة في نراجم أئمة النحو واللغة - الفيروزآبادي : مجد الدين أبو طاهر

محمد بن بعقوب ، طبعة دار سعد الدين للطباعة والنشر و النوزيع - طا -

$$
\cdot \vec{r} \cdot \cdot
$$

r ا البيان و التبيين - الجاحظ : أبو عثمان عمرو بن بحر بن محبوب ، طبعة دار

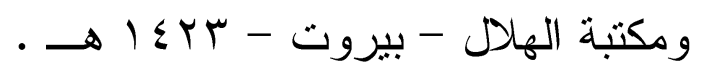

با - تاريخ العلماء النحويين هن البصريين والكوفيين وغيرهم - التنوخي : أبو المحاسن المفضل بن محمد بن مسعر المعري ، تحقيق : الدكتور عبد الفتاح محمد الحلو ، طبعة هجر للطباعة و النشر والتوزيع والإعلان - طب - القاهرة - $1994-$

ع ا- تاريخ النحو العربي في المشرق و المغرب - د. محمد المختار ولد أبّاه ،

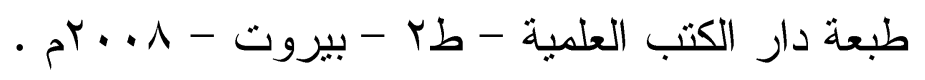

10- التبيين عن مذاهب النحويين البصريين والكوفيين - العكبري : أبو البقاء محب الدين عبد الله بن الحسين بن عبد الله ، تحقيق : د. عبد الرحمن العثمين

$$
\text { ، طبعة دار الغرب الإسلامي - طا - } 1917 \text { ام • }
$$

17

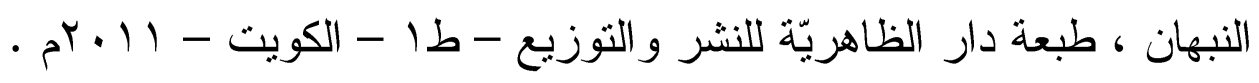
IV الجنى الداني في حروف المعاني - المر ادب : أبو محمد بدر الدين حسن بن قاسم بن عبد الله بن عليّ ، تحقيق : د فخر الدين قباوة / الأستاذ محمد نديم

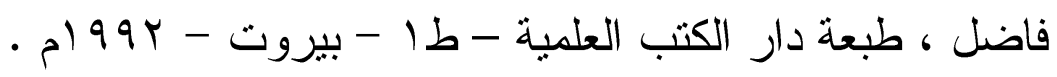


11- حانثية الصبان على شرح الأشمونى لألفية ابن مالك - الصبان : أبو العرفان

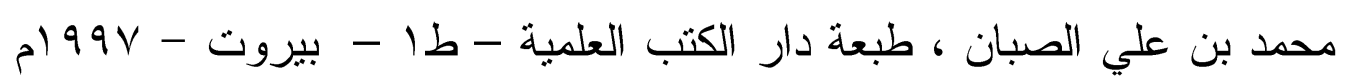

9 1- الخصائص - ابن جنّي : أبو الفتح عثمان بن جني ، طبعة الهيئة المصرية

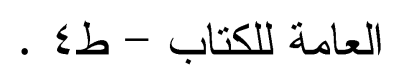

• ץ- الدليل إلى المتون العلمية - عبد العزيز بن إبراهيم بن قاسم ، طبعة دار

$$
\text { الصميعي للنشر و التوزيع - طا - الرياض - . . . بrم • }
$$

اب - شذرات الذهب في أخبار من ذهب - ابن العماد الحنبلي : أبو الفلاح عبد الحي بن أحمد بن محمد ، تحقيق : محمود الأرناؤوط ، خرج أحاديثه : عبد الدئ

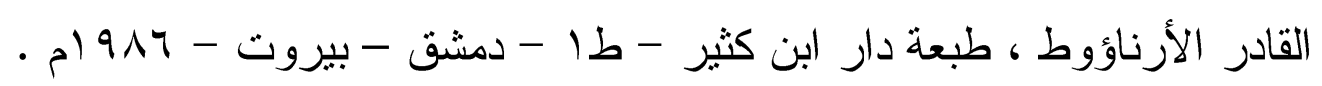
r ب-شرح ابن عقيل على ألفية ابن مالك - ابن عقيل : عبد الله بن عبد الرحمن العقبلي الهمداني المصري ، تحقيق : محمد محيي الدين عبد الحميد ، طبعة دار

$$
\text { التزراث - ط.r - القاهرة - . } 91 \text { ام . }
$$

بr-شرح الأجرومية - الأسمري : أبو محمد صالح بن محمد بن حسن آل عميرٍ

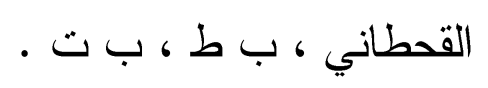

ـ ك-شرح تسهيل الفوائد - ابن مالك : أبو عبد الله جمال الدين محد بن عبد الله بن مالك الطائي الجياني ، تحقيق : د. عبد الرحمن السيد / د. محمد بدوي

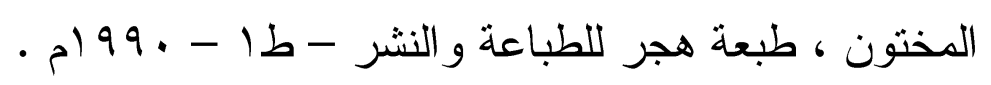

هץ-شرح الكافية الثافية - ابن مالك : ، أبو عبد الله جمال الدين محمد بن عبد الله بن مالك الطائي ، تحقيق : عبد المنعم أحمد هريدي ، طبعة مركز البحث العلمي وإحياء التزاث الإسلامي - جامعة أم القرى - طا - مكة المكرمة . 
بr-شرح منن الأجروميّة - المكودي : أبو زيد عبد الرحمن بن علي بن صالح ،

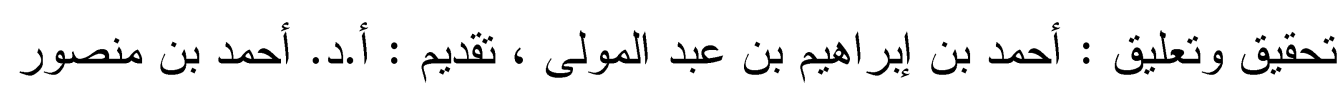

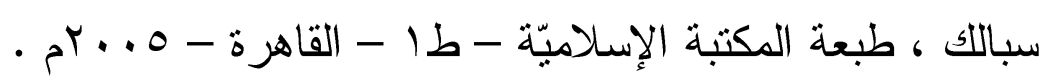

- ش - شرح المفصل - ابن بعيش : أبو البقاء موفق الدين بعيش بن علي بن بعيش

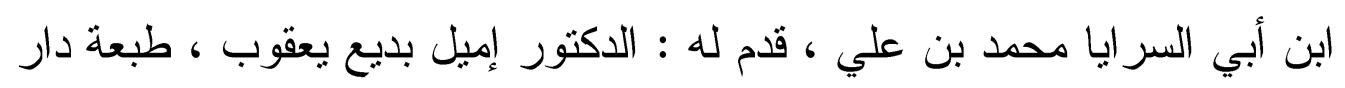

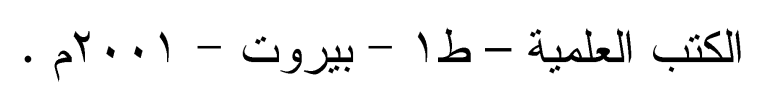

^ץ- طبقات فحول الثعر اء - محمد بن سلام الجمحي ، تحقيق : محمود محد شاكر ، طبعة دار المدني - جدة . وץ- فهرس الفهارس والأثبات ومعجم المعاجم و المشيخات و المسلسلات - عبد الحيّ الكتاني : محمد عبد الحيّ بن عبد الكبير بن محمد الحسني الإدريسي و

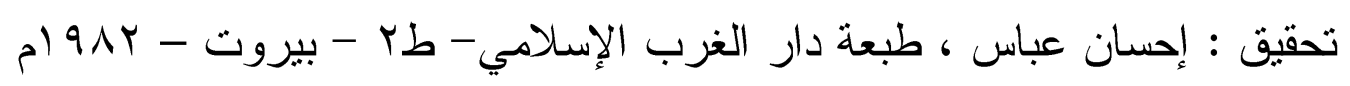

• ب- الكامل في اللغة والأدب - المبرد : أبو العباس محمد بن يزيد ، تحقيق : محمد أبو الفضل إبر اهيم ، طبعة دار الفكر العربي - طب - القاهرة - 99 ام ولئ

اب- كثف الظنون عن أسامي الكتب و الفنون - حاجي خليفة : مصطفى بن عبد الله كاتب جلبي القسطنطيني ، طبعة مكتبة المثنى - بغداد - 19 ام . rس-منن الآجرومية - ابن آجُرُوم : أبو عبد الله محمد بن محمد بن داود بهد الصنهاجي ، طبعة دار الصميعي- 991 ام . rr- المدارس النحوية - شوفي ضيف : أحمد شوفي عبد السلام ضيف ، طبعة

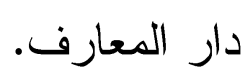


ججلة الآواب / العرو r|1

ع ب- معجم الأدباء - باقوت الحموي : شهاب الدين أبو عبد الله ياقوت بن عبد الله

، نحقيق : إحسان عباس ، طبعة دار الغرب الإسلاهي- طا - بيروت -

$$
\text { - 1994 }
$$

هب- مغني اللبيب عن كتب الأعاريب - ابن هشام : أبو محمد جمال الدين عبد الله

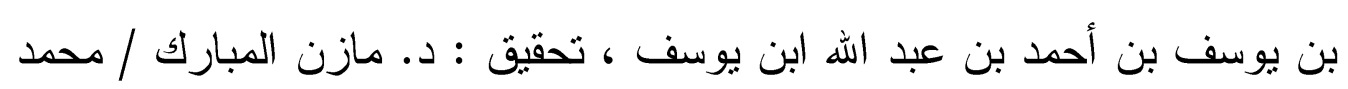
علي حمد الله ، طبعة دار الفكر - ط7 - دمشق - 910 ام .

بس- من تاريخ النحو العربي - سعيد بن محمد بن أحمد الأفغاني ، طبعة مكتبة - الفلاح

كز نز هة الألباء في طبقات الأدباء - ابن الأنباري : أبو البركات كمال الدين عبد

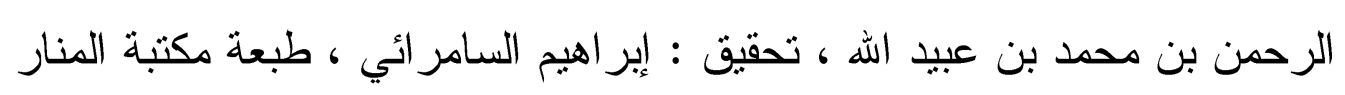

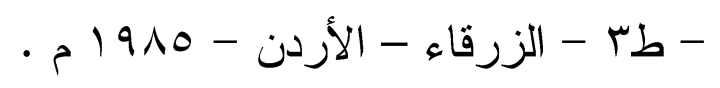

^r- نشأة النحو وتاريخ أشهر النحاة - الثيخ محمد الطنطاوي ، تحقيق : أبي محمد عبد الرحمن بن محمد بن إسماعيل ، طبعة مكتبة إحباء النراث الإسلامي

$$
\text { . }
$$

وب- هدية العارفين أسماء المؤلفين و آثار المصنفين - إسماعيل بن محمد أمين بن

مير سليم ، طبع بعناية وكالة المعارف الجليلة في مطبعتها البهية استانبول - 